In cooperation with the Texas Commission on Environmental Quality

\title{
Statewide Analysis of the Drainage-Area Ratio Method for 34 Streamflow Percentile Ranges in Texas
}

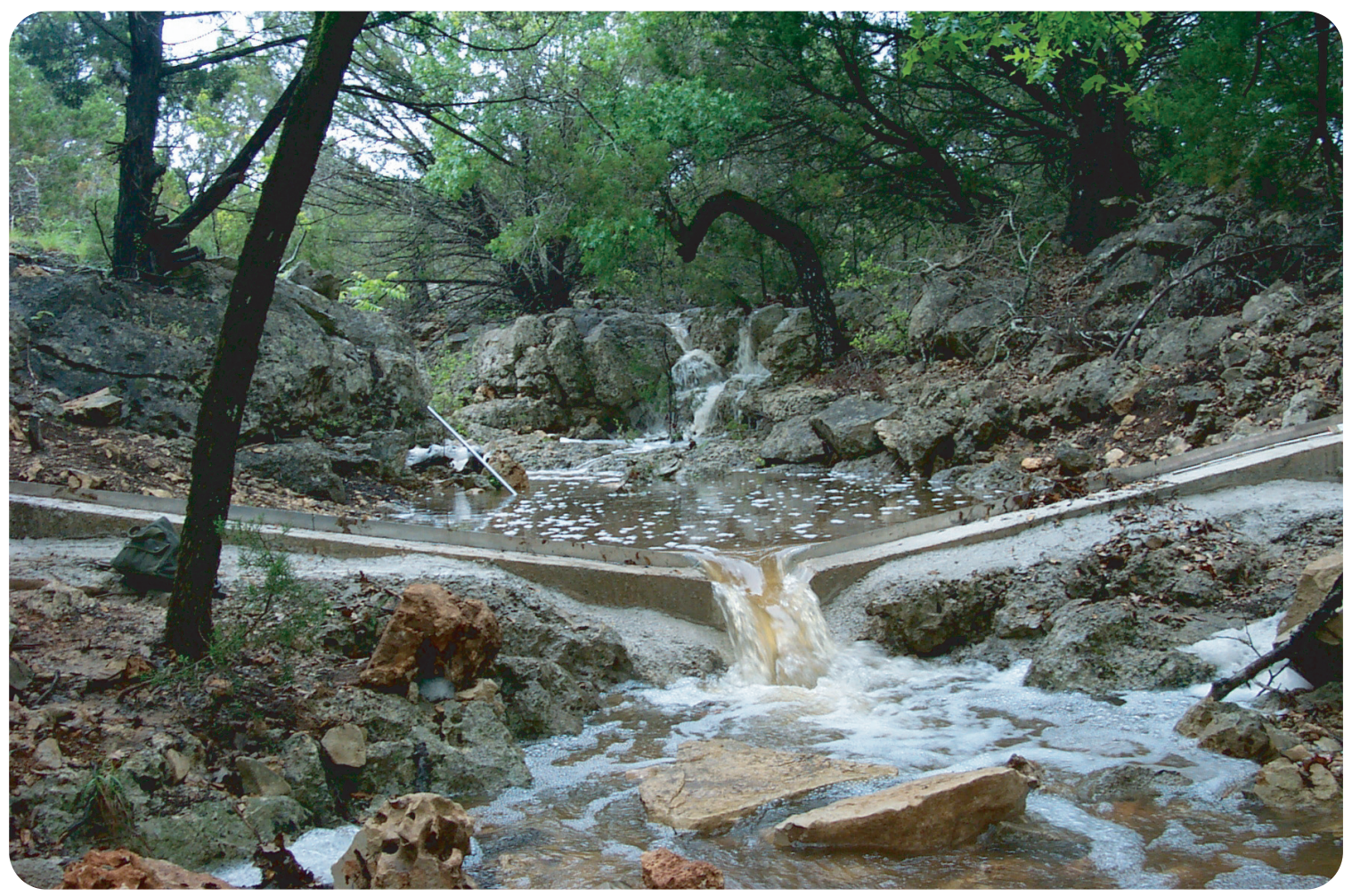

Scientific Investigations Report 2006-5286 
Cover. Unnamed tributary to Honey Creek at Honey Creek State Natural Area, Comal County, Texas, April 2001. 


\section{Statewide Analysis of the Drainage-Area Ratio Method for 34 Streamflow Percentile Ranges in Texas}

By William H. Asquith, Meghan C. Roussel, and Joseph Vrabel

In cooperation with the Texas Commission on Environmental Quality

Scientific Investigations Report 2006-5286 


\title{
U.S. Department of the Interior DIRK KEMPTHORNE, Secretary
}

\author{
U.S. Geological Survey \\ Mark Myers, Director
}

\section{U.S. Geological Survey, Reston, Virginia: 2006}

For more information about the USGS and its products:

Telephone: 1-888-ASK-USGS

World Wide Web: http://www.usgs.gov/

Any use of trade, product, or firm names in this publication is for descriptive purposes only and does not imply endorsement by the U.S. Government.

Although this report is in the public domain, permission must be secured from the individual copyright owners to reproduce any copyrighted materials contained within this report.

Suggested citation:

Asquith, W.H., Roussel, M.C., and Vrabel, Joseph, 2006, Statewide analysis of the drainage-area ratio method for 34 streamflow percentile ranges in Texas: U.S. Geological Survey Scientific Investigations Report 2006-5286, 34 p., 1 appendix. 


\section{Contents}

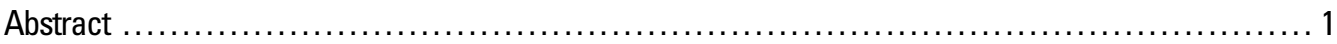

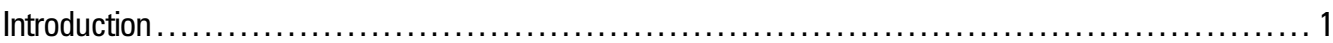

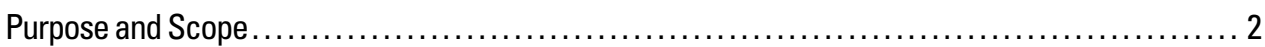

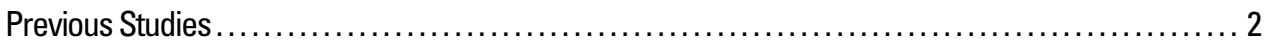

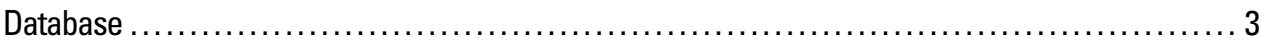

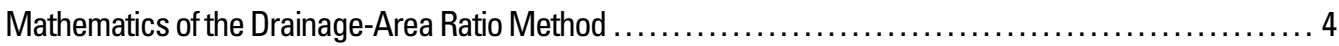

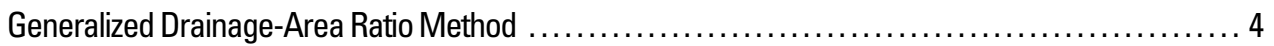

Parameter Estimation for Generalized Drainage-Area Ratio Method $\ldots \ldots \ldots \ldots \ldots \ldots \ldots \ldots \ldots \ldots \ldots \ldots \ldots \ldots \ldots \ldots \ldots \ldots \ldots$

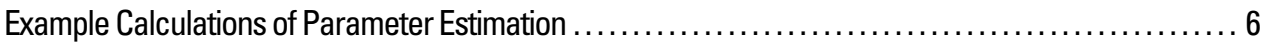

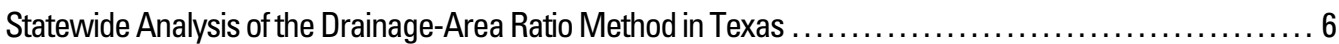

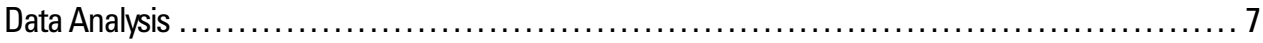

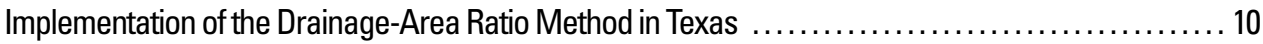

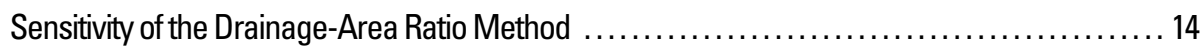

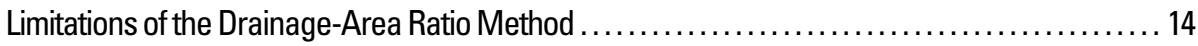

Example Application of the Drainage-Area Ratio Method ........................... 15

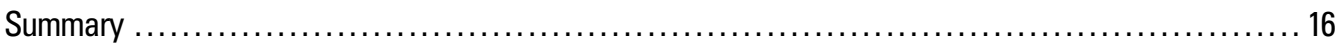

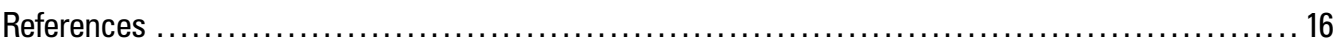

Appendix 1 - Summary of the Drainage-Area Ratio Method for Daily Mean Streamflow in Texas .........1-1

Demonstration of the Drainage-Area Ratio Method —Estimating Streamflow for Selected

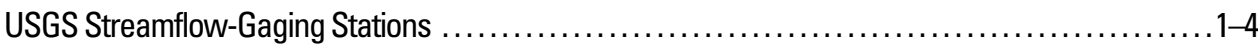

Demonstration of the Drainage-Area Ratio Method - Estimating Streamflow for Selected Monitoring Sites of the Texas Commission on Environmental Quality .........................

Figures 1.1-1.10:

1.1. Comparison of $\phi(F)$ values using station 07299670 to estimate daily mean streamflow

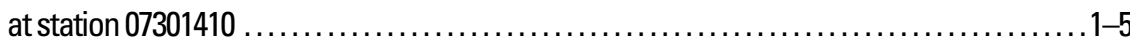

1.2. Comparison of $\phi(F)$ values using station 07301410 to estimate daily mean streamflow

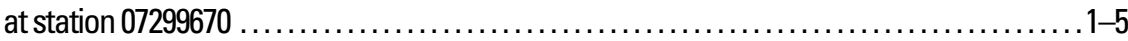

1.3. Comparison of $\phi(F)$ values using station 08019000 to estimate daily mean streamflow

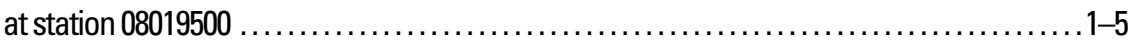

1.4. Comparison of $\phi(F)$ values using station 08019500 to estimate daily mean streamflow

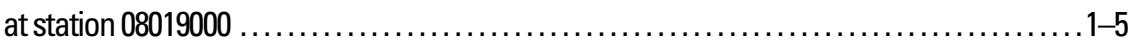

1.5. Comparison of $\phi(F)$ values using station 08037050 to estimate daily mean streamflow

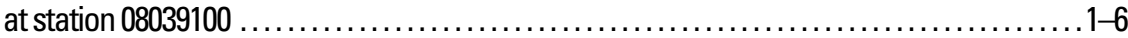

1.6. Comparison of $\phi(F)$ values using station 08039100 to estimate daily mean streamflow

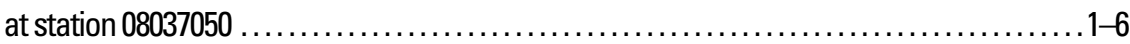

1.7. Comparison of $\phi(F)$ values using station 08167000 to estimate daily mean streamflow

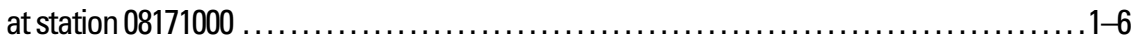

1.8. Comparison of $\phi(F)$ values using station 08171000 to estimate daily mean streamflow

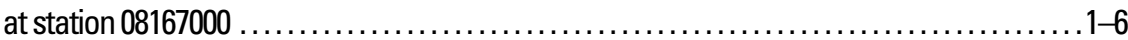

1.9. Comparison of $\phi(F)$ values using station 08198000 to estimate daily mean streamflow at station 08200000 
1.10. Comparison of $\phi(F)$ values using station 08200000 to estimate daily mean streamflow at station 08198000 .

Tables 1.1-1.2:

1.1. Summary of comparison of drainage-area ratio method using $\phi=1$ and $\phi_{\mathrm{var}}(F)$ for selected USGS streamflow-gaging stations . ....

1.2. Ungaged sites provided by the Texas Commission on Environmental Quality for inclusion in demonstration of the drainage-area ratio method

\section{Figures}

1. Map showing locations of U.S. Geological Survey streamflow-gaging stations in Texas with at least 1 year of daily mean streamflow data 4

2. Example output from drainage-area ratio computation run for an arbitrary station pair and the 98-99 and 99-100 percentile ranges

3-6. Graphs showing relation between:

3. Separation distance and exponent of drainage-area ratio method for the fourth quartile (75-100 percentile range) of daily streamflow in Texas

4. Absolute value of logarithm of ratio of drainage areas and exponent of drainage-area ratio method for fourth quartile (75-100 percentile range) of daily streamflow in Texas for station pairs with separation distance less than or equal to 100 miles

5. Conditional exponents $(\phi)$ of drainage-area ratio method and percentile of daily mean streamflow in Texas by streamflow-frequency width interval 12

6. Conditional bias-correction factors $(K)$ of drainage-area ratio method and percentile of daily mean streamflow in Texas by streamflow-frequency width interval

7. Example application of the drainage-area ratio method 15

\section{Tables}

1. U.S. Geological Survey streamflow-gaging stations in Texas with at least 1 year of daily

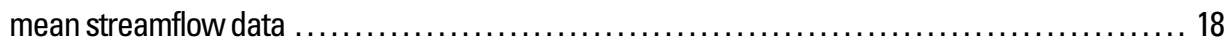

2. Example of parameter estimation for the generalized drainage-area ratio method ............. 7

3. Summary statistics of drainage-area ratio method for each of the 34 percentile ranges of

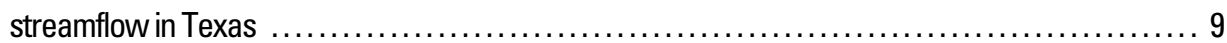

4. Summary statistics of drainage-area ratio method conditional on separation distance and relative drainage area for each of the 34 percentile ranges of streamflow in Texas ............ 11

5. Suggested exponents for the drainage-area ratio method in Texas ....................... 13 


\section{Conversion Factors}

\section{Inch/Pound to SI}

\begin{tabular}{|c|c|c|}
\hline Multiply & By & To obtain \\
\hline \multicolumn{3}{|c|}{ Length } \\
\hline mile (mi) & 1.609 & kilometer (km) \\
\hline \multicolumn{3}{|c|}{ Area } \\
\hline square mile $\left(\mathrm{mi}^{2}\right)$ & 2.590 & square kilometer $\left(\mathrm{km}^{2}\right)$ \\
\hline \multicolumn{3}{|c|}{ Flow rate } \\
\hline cubic foot per second $\left(\mathrm{ft}^{3} / \mathrm{s}\right)$ & 0.02832 & cubic meter per second $\left(\mathrm{m}^{3} / \mathrm{s}\right)$ \\
\hline
\end{tabular}

\section{SI to Inch/Pound}

\begin{tabular}{lcll}
\hline & Multiply & By & To obtain \\
\hline & Length & & \\
\hline meter $(\mathrm{m})$ & 3.281 & foot $(\mathrm{ft})$ & \\
kilometer $(\mathrm{km})$ & 0.6214 & mile $(\mathrm{mi})$ & \\
\hline
\end{tabular}




\title{
Statewide Analysis of the Drainage-Area Ratio Method for 34 Streamflow Percentile Ranges in Texas
}

\author{
By William H. Asquith, Meghan C. Roussel, and Joseph Vrabel
}

\section{Abstract}

The drainage-area ratio method commonly is used to estimate streamflow for sites where no streamflow data are available using data from one or more nearby streamflow-gaging stations. The method is intuitive and straightforward to implement and is in widespread use by analysts and managers of surface-water resources. The method equates the ratio of streamflow at two stream locations to the ratio of the respective drainage areas. In practice, unity often is assumed as the exponent on the drainage-area ratio, and unity also is assumed as a multiplicative bias correction. These two assumptions are evaluated in this investigation through statewide analysis of daily mean streamflow in Texas. The investigation was made by the U.S. Geological Survey in cooperation with the Texas Commission on Environmental Quality. More than 7.8 million values of daily mean streamflow for 712 U.S. Geological Survey streamflow-gaging stations in Texas were analyzed. To account for the influence of streamflow probability on the drainage-area ratio method, 34 percentile ranges were considered. The 34 ranges are the 4 quartiles $(0-25,25-50,50-75$, and 75-100 percent), the 5 intervals of the lower tail of the streamflow distribution (0-1, 1-2, 2-3, 3-4, and 4-5 percent), the 20 quintiles of the 4 quartiles $(0-5,5-10,10-15,15-20,20-25,25-30,30-35$, $35-40,40-45,45-50,50-55,55-60,60-65,65-70,70-75$, 75-80, 80-85, 85-90, 90-95, and 95-100 percent), and the 5 intervals of the upper tail of the streamflow distribution (95-96, 96-97, 97-98, 98-99 and 99-100 percent). For each of the $253,116(712 \times 711 / 2)$ unique pairings of stations and for each of the 34 percentile ranges, the concurrent daily mean streamflow values available for the two stations provided for station-pair application of the drainage-area ratio method. For each station pair, specific statistical summarization (median, mean, and standard deviation) of both the exponent and biascorrection components of the drainage-area ratio method were computed. Statewide statistics (median, mean, and standard deviation) of the station-pair specific statistics subsequently were computed and are tabulated herein. A separate analysis considered conditioning station pairs to those stations within 100 miles of each other and with the absolute value of the logarithm (base-10) of the ratio of the drainage areas greater than or equal to 0.25 . Statewide statistics of the conditional stationpair specific statistics were computed and are tabulated. The conditional analysis is preferable because of the anticipation that small separation distances reflect similar hydrologic conditions and the observation of large variation in exponent estimates for similar-sized drainage areas. The conditional analysis determined that the exponent is about 0.89 for streamflow percentiles from 0 to about 50 percent, is about 0.92 for percentiles from about 50 to about 65 percent, and is about 0.93 for percentiles from about 65 to about 85 percent. The exponent decreases rapidly to about 0.70 for percentiles nearing 100 percent. The computation of the bias-correction factor is sensitive to the range analysis interval (range of streamflow percentile); however, evidence suggests that in practice the drainage-area method can be considered unbiased. Finally, for general application, suggested values of the exponent are tabulated for 54 percentiles of daily mean streamflow in Texas; when these values are used, the bias correction is unity.

\section{Introduction}

Analysts and managers of surface-water resources often require streamflow data for locations where no data were collected or for streamflow-gaging stations for periods during which the gage was not in operation. Techniques used to estimate streamflow for locations where no streamflow data were collected include the drainage-area ratio method, regional statistics, regression (in various forms), and rainfall-runoff modeling. Only the drainage-area ratio method is considered here. The method is considered in the specific context of estimating daily mean streamflow at ungaged locations using daily mean streamflow from gaged locations. The term ungaged requires specific clarification. An ungaged location has no historical streamflow information. 


\section{Statewide Analysis of the Drainage-Area Ratio Method for 34 Streamflow Percentile Ranges in Texas}

The drainage-area ratio method is a technique that statistically transfers same-day streamflow information from one location to another on the basis of the drainage areas of the two locations. The method is algebraically simple and is the most straightforward of the techniques to implement. In one formulation, the drainage-area ratio method is (Emerson and others, 2005)

$$
Y=X\left(\frac{A_{Y}}{A_{X}}\right)^{\phi},
$$

where $Y$ is the streamflow for the ungaged location, $X$ is the streamflow at a gaging station, and $A_{Y}$ and $A_{X}$ are the drainage areas for the ungaged location and the streamflow-gaging station, respectively. In widespread practice the exponent $\phi=1$, and therefore the drainage-area ratio method is a direct proration of flow based on streamflow per unit area (square kilometers or square miles).

Analysts at the Texas Commission on Environmental Quality (TCEQ) use streamflow estimates for regulatory stream locations lacking a gaging station (ungaged locations). For example, if water-quality data are collected for the regulatory stream location and a concurrent streamflow measurement is not made, then the streamflow at the location requires estimation. The drainage-area ratio method often is applied and uses concurrent-in-time (same day) streamflow for one or more nearby and operating streamflow-gaging stations. The drainage-area ratio method also is used for numerous other applications requiring streamflow transference. Therefore, examination of the drainage-area ratio method for daily streamflow estimation in Texas is needed. Beginning in 2005, the U.S. Geological Survey (USGS), in cooperation with TCEQ, initiated an investigation of the exponent and bias-correction factor (to be discussed) of the drainage-area ratio method in Texas.

Finally, emphasis is needed that the primary purpose of the drainage-area ratio method reported here is for daily mean streamflow estimation for ungaged locations. For circumstances in which limited streamflow data exist for a location of interest not gaged on a day for which a streamflow estimate is required, alternative techniques that utilize the limited streamflow information should be used to provide a calibrated drainage-area ratio method or a regression between the sameday streamflow for data for the location of interest and a nearby streamflow-gaging station.

\section{Purpose and Scope}

The purpose of this report is to summarize the results of a statewide analysis of the exponent and bias-correction factor of the drainage-area ratio method in Texas. This report also offers values of the exponent and bias-correction factor for general application of the drainage-area ratio method for statistically transferring daily mean streamflow from gaged locations to ungaged locations in Texas. The analysis for this report uses nearly the entire database of daily mean streamflow values available for more than 700 USGS streamflow-gaging stations in Texas. The analysis is statewide in nature and does not address regional or seasonal variations in the drainage-area ratio method should such variations exist.

\section{Previous Studies}

Hirsch (1979) evaluates the drainage-area ratio method with $\phi=1$, regional regression equations, linear regression equations, and log-log regression equations to reconstruct streamflow record. Although streamflow reconstruction nominally is not the purpose of the drainage-area ratio method considered here, there is considerable analytical overlap with the objective of streamflow transference and streamflow reconstruction. Hirsch (1979) concludes that the other techniques are superior to the drainage-area ratio method for gages with some historical record. If streamflow is being estimated for a historically ungaged location, however, then the streamflow characteristics at the location are unknown, and how well the drainage-area ratio method works also is unknown.

In the context of estimating low-flow statistics for Massachusetts streams, Ries and Friez (2000, p. 1) conclude that "the drainage-area ratio method [generally] is as accurate or more accurate than regression estimates when the drainage-area ratio for [the] ungaged [location] is between 0.3 and 1.5 times the drainage area of the [streamflow-gaging station]." Ries and Friez consider the drainage-area ratio method with $\phi=1$.

Wurbs (2005) provides a reference manual for a computer software program used for water-right evaluation for the State of Texas. This program is in widespread use in Texas. Within the algorithms of the program, the drainage-area ratio method is used under a variety of circumstances to transfer streamflow data from one location to another. The method has $\phi=1$.

A cursory search of the drainage-area ratio method on the Internet finds numerous documents referencing the use of the method with $\phi=1$. Four examples are provided. Perry and others (2002) apply the drainage-area ratio method with $\phi=1$ for estimation of median streamflow values in Kansas. In the context of streamflow estimation for drought conditions, the Michigan Department of Environmental Quality (2005) states that "[the drainage-area ratio method] is used for gaged or ungaged watersheds. The drought flows at a specific site are computed based on the ratio of the drainage areas between that site and a USGS [streamflow-] gaging station. A USGS station with similar watershed characteristics is used for this method." California Environmental Protection Agency, State Water Resources Control Board, Water Rights (2005) suggests the use of the drainage-area ratio method with $\phi=1$ for purposes of water-right evaluation and permitting in California. Oregon State University (2005) suggests techniques for streamflow estimation at ungaged locations in Oregon in which the drainage-area ratio method is used with $\phi=1$.

Emerson and others (2005) describe an evaluation of the drainage-area ratio method for the Red River of the North Basin in North Dakota and Minnesota in the context of the estimation 
of winter (January, February, November, and December), spring (March, April, and May), and summer (June, July, August, September, and October) monthly mean streamflow. They also included a detailed explanation of the general mathematics of the drainage-area ratio. The $\phi$ exponents on the winter, spring, and summer equations are $0.85,0.91$, and 1.02 , respectively. Bias-correction factors (not indicated in equation 1 but shown in equation 10) for the winter, spring, and summer equations are 1.24, 1.02, and 1.06, respectively.

Asquith and Thompson (2005) provide statewide regression analysis of the 2-, 5-, 10-, 25-, 50-, and 100-year annual peak streamflow for Texas using data considered by Asquith and Slade (1997). Asquith and Thompson (2005) develop regression equations for each of the six T-year recurrence intervals that use only logarithms of streamflow and drainage area. The exponent on drainage area is mathematically compatible with the $\phi$ exponent of the drainage-area ratio method considered in section "Statewide Analysis of the Drainage-Area Ratio Method in Texas" of this report. The general value of the exponent from Asquith and Thompson (2005) is about 0.51. In this report, the value of 0.51 for the exponent is compared to the results of the current (2006) investigation. For additional perspective, Stamey and Hess (1993) report numerous equations for annual peak streamflow frequency estimation in Georgia using drainage area; a general value for the exponent on drainage area is about 0.6 .

In general, the literature is synthesized as follows: The drainage-area ratio method is almost universally used with $\phi=1$, and the method is considered unbiased. Further, the majority of the literature appears to involve the application of the method and not evaluation of the method in a statistical sense. Emerson and others (2005) appears to be an exception.

\section{Database}

The statewide analysis of the drainage-area ratio method reported here is based on the period of record of daily mean streamflow and the (contributing) drainage areas for 712 USGS streamflow-gaging stations (fig. 1). The stations and ancillary information are listed in table 1 (at end of report). The geographic distance between each station pair was computed. The mean distance is about 221 miles and the standard deviation is about 116 miles.

The stations have at least 1 year (365 days) of daily mean streamflow record and a documented drainage area. The data and drainage areas for the 712 stations were acquired from U.S. Geological Survey (2005). The year in which the first daily mean streamflow record occurs is 1898 . The last water year ${ }^{1}$ of record is 2004 . The total number of daily values available is $7,844,761$. Streamflow-gaging stations that monitor spring flow or only stage (water level) were not used. Further, partial record streamflow-gaging stations were not used because complete flow-duration curves are needed.

For the statewide analysis reported here, no further subselection of stations according to streamflow regulation or general land use of the watershed (undeveloped, developed, regulated, urban, and other) was made. In addition, the entire period of record for each station was used. Graphical review or statistical evaluation of potential temporal trends with the purpose of rejecting (or accepting) specific stations or specific portions of the data record for some stations was not made. Whereas the rigorous review of the time series of the data for differing combinations of watersheds is useful and particularly important for evaluation of the drainage-area ratio method on a localized or site-specific basis, the analysis in this report is intended to establish a general parameterization of the drainage-area ratio method in Texas.

Streamflow for a particular location generally exhibits considerable variation. Because the primary purpose of the drainage-area ratio method is to transfer streamflow from a gaging station to an ungaged location, a specific drainage-area ratio equation for the streamflow regime exhibited at the streamflow-gaging station is needed. For this report streamflow regime is specified through selection of a range of streamflow percentile (nonexceedance probability) using flow-duration curves. Flow-duration curves are a common statistical concept and graph that show the fraction or percent of time that the daily mean streamflow magnitude exceeds a specified value (Dingman, 2002). Flow-duration curves are thoroughly discussed by Vogel and Fennessey (1994 and 1995).

At the beginning of this investigation, four primary ranges of streamflow percentile [ $100 \times($ nonexceedance probability)] were considered and are the four quartiles of streamflow or the ranges of 0-25, 25-50, 50-75, and 75-100 percent; however, further subdivision was deemed necessary. A particularly acute problem for TCEQ analysts and others is the transference of streamflow for low-flow conditions; therefore, the first quartile (0-25 percent) was further subdivided into quintiles to form the $0-5,5-10,10-15,15-20$, and 20-25 percent ranges. A common problem for analysts involved in infrastructure design (such as bridge and culverts) is the transference of high magnitude streamflow values (annual peak streamflow). Although this investigation is limited to daily mean streamflow values and not peak streamflow, to facilitate comparison of the drainage-area ratio method to existing equations for estimation of peak streamflow (see Asquith and Thompson, 2005) and other large values of streamflow, the fourth quartile (75-100 percent) was subdivided into quintiles to form the 75-80, 80-85, 85-90, 90-95, and 95-100 percent ranges.

From exploratory data analysis conducted between August 2005 and November 2005, further subdivision of the flowduration curve far into the lower and upper tails was deemed necessary. The 95-96, 96-97, 97-98, 98-99, and 99-100

\footnotetext{
${ }^{1}$ Water year is the 12-month period October 1 through September 30. The water year is designated by the calendar year in which it ends and which includes 9 of the 12 months. Thus, the year ending September 30, 2004, is called the "2004 water year."
} 


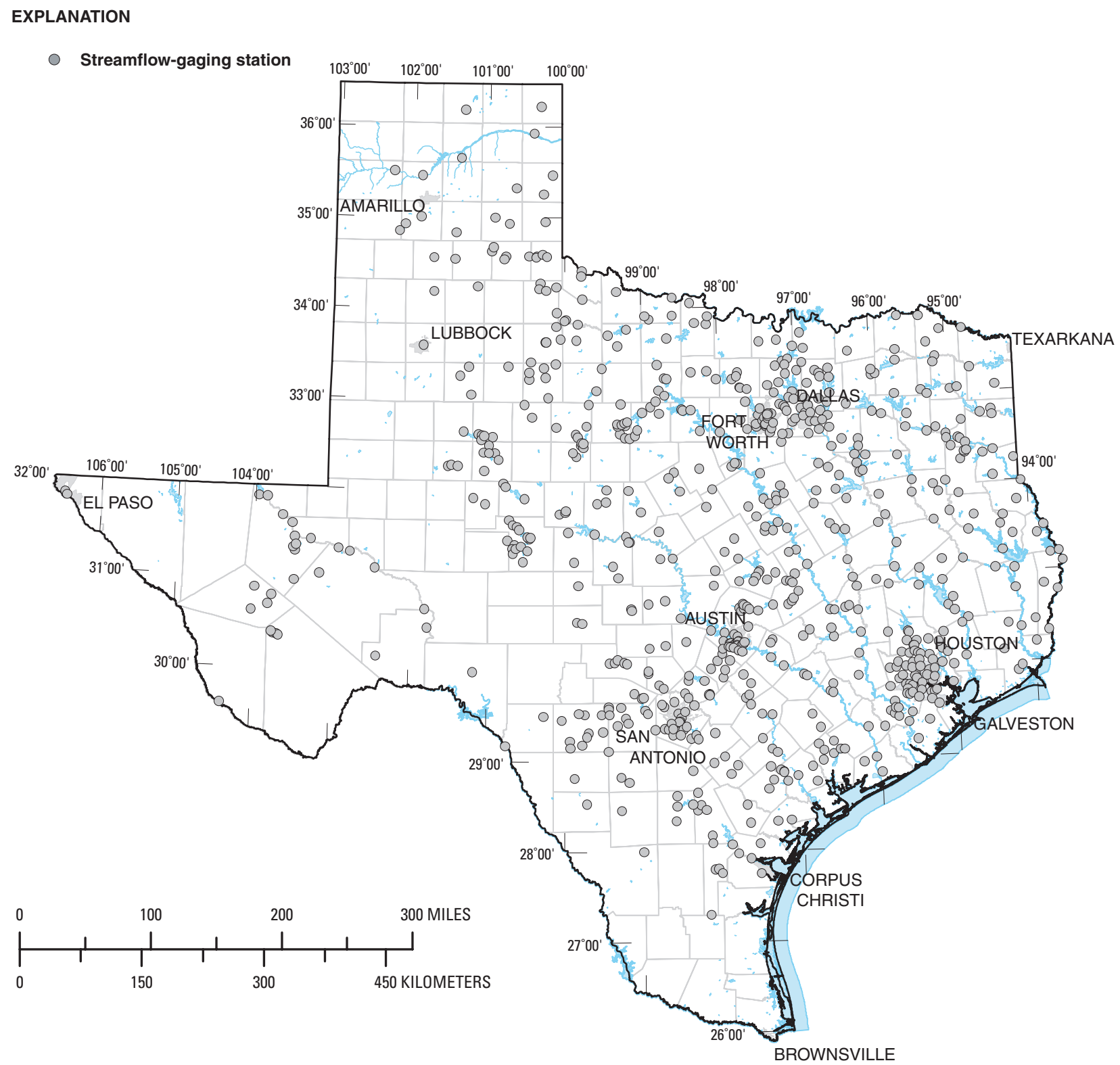

Figure 1. Locations of U.S. Geological Survey streamflow-gaging stations in Texas with at least 1 year of daily mean streamflow data.

percent ranges also were selected to provide more detailed analysis for the upper tail of the streamflow distribution, and in order to maintain symmetry, the lower tail of the streamflow distribution was subdivided into the $0-1,1-2,2-3,3-4$, and 4-5 percent ranges.

Finally, for purposes of continuity of analysis, the middle two quartiles also were subdivided into quintiles to form the $25-30,30-35,35-40,40-45,45-50,50-55,55-60,60-65$, $65-70$, and $70-75$ percent ranges. Thus, the entire spectrum of streamflow frequency is represented through 205 -percent wide ranges. Thus, a total of 34 streamflow percentile ranges are considered.

\section{Mathematics of the Drainage-Area Ratio Method}

\section{Generalized Drainage-Area Ratio Method}

The simplest drainage-area ratio method is based on the assumption that the streamflow for a site of interest can be estimated by multiplying the ratio of the drainage area for the site of interest and the drainage area for a nearby streamflow-gaging station by the streamflow for the nearby gaging station. Thus, 
the simplest drainage-area ratio method has an exponent of unity and is given by

$$
\widehat{Q_{1}}=Q_{2}\left(\frac{A_{1}}{A_{2}}\right)^{1}
$$

where $\widehat{Q_{1}}$ is the estimated streamflow, in cubic length per time for the ungaged location; $Q_{2}$ is the streamflow, in cubic length per time for the streamflow-gaging station; $A_{1}$ is the drainage area, in units of square length, for ungaged location; and $A_{2}$ is the drainage area, in units of square length, for the streamflowgaging station. Following the nomenclature shown, the actual streamflow for the site of interest is denoted as $Q_{1}$ and estimated streamflow for the gaging station is denoted as $\widehat{Q}_{2}$.

For the simplest drainage-ratio method (equation 2), assumptions are made that the exponent $\phi$ of $\left(A_{1} / A_{2}\right)$ is 1 , and the equation is unbiased. The term unbiased implies that the expected value of the estimated streamflow equals the true streamflow value. To evaluate the simplest drainage-ratio method, a generalized drainage-area ratio method can be formulated. The streamflow for the ungaged location is estimated from drainage area by using the following

$$
\log \left(\widehat{Q_{1}}\right)=c+\phi \log \left(A_{1}\right)
$$

where the $\log (x)$ function is a base- $10 \operatorname{logarithm}, c$ represents a constant or intercept, and $\phi$ represents a slope. By generality, the streamflow for the gaging station is estimated by

$$
\log \left(\widehat{Q_{2}}\right)=c+\phi \log \left(A_{2}\right) \text {. }
$$

To obtain an unbiased estimate of streamflow for the site of interest, consideration of an error (residual) term is required

$$
\log \left(Q_{1}\right)=c+\phi \log \left(A_{1}\right)+\varepsilon_{1},
$$

where $\varepsilon_{1}=\log \left(Q_{1}\right)-\log \left(\widehat{Q_{1}}\right)$ is the residual. Again by generality, the unbiased streamflow for the gaging station is given by

$$
\log \left(Q_{2}\right)=c+\phi \log \left(A_{2}\right)+\varepsilon_{2},
$$

where $\varepsilon_{2}=\log \left(Q_{2}\right)-\log \left(\widehat{Q}_{2}\right)$ is the residual. For unbiased estimation of streamflow in linear-space (non log), the expectation of the linear-space residuals is

$$
E\left[10^{\varepsilon}\right]=1 .
$$

Therefore, after converting equations 5 and 6 to linear-space and forming ratios, the following result

$$
\begin{gathered}
\frac{Q_{1}}{Q_{2}}=\kappa_{1}\left(\frac{A_{1}}{A_{2}}\right)^{\phi} \text { and } \\
\frac{Q_{2}}{Q_{1}}=\kappa_{2}\left(\frac{A_{2}}{A_{1}}\right)^{\phi},
\end{gathered}
$$

where $\kappa_{1}$ and $\kappa_{2}$ represent bias correction terms that have the same statistical properties. Each bias-correction factor is chosen such that $E\left[10^{\varepsilon_{1}}\right]=E\left[10^{\varepsilon_{2}}\right]=1$. The ratio in linear-linear space between equations 8 and 9 represents a generalized drainage-area ratio method and is

$$
\frac{Q_{1}}{Q_{2}}=K\left(\frac{A_{1}}{A_{2}}\right)^{\phi}
$$

where $K$ is a single bias correction term. Using symmetry arguments, the expected values of $\kappa_{1}$ and $\kappa_{2}$ are the same and the bias-correction factor is defined as the expected value of either variable or for smaller sampling variance the expected value of the combination of $\kappa_{1}$ and $\kappa_{2}$ values.

\section{Parameter Estimation for Generalized Drainage-Area Ratio Method}

In practice the drainage-area ratio method is used to estimate streamflow at an ungaged location by using streamflow from a nearby gaging station; however, the analysis of $K$ and $\phi$ requires joint analysis of the streamflow for two gaging stations. The choice of the subscript 1 for the site of interest and subscript 2 for the streamflow-gaging station is arbitrary. Furthermore, one station can be used to estimate streamflow at the other and in turn the other station can be used to estimate streamflow for the former. With the bias correction, the streamflow for each of the two stations were estimated by using the following

$$
\begin{gathered}
\overparen{Q_{1}}=K Q_{2}\left(\frac{A_{1}}{A_{2}}\right)^{\phi} \text { and } \\
\overparen{Q_{2}}=K Q_{1}\left(\frac{A_{2}}{A_{1}}\right)^{\phi} .
\end{gathered}
$$

The parameter $\phi$ can be estimated from daily mean streamflow data with assumption that $K$ initially is 1 . The $\phi_{i}$ for the $i$ th day that streamflow data are available for each station is

$$
\phi_{i}=\frac{\log \left(Q_{1 i} / Q_{2 i}\right)}{\log \left(A_{1} / A_{2}\right)} .
$$

The mean or expected value of $\phi$ is

$$
\bar{\phi}=\frac{1}{n} \sum_{i=1}^{n} \phi_{i},
$$

where $n$ is the sample size (number of days of record). After the mean exponent is estimated by equation 14, the residuals of equations 11 and 12 are computed, and in turn, the two estimates for the bias-correction term for the $i$ th day of record are computed from $\bar{\phi}$ by

$$
\begin{aligned}
{ }_{12} \kappa_{i}= & \frac{Q_{1 i}}{Q_{2 i}\left(\frac{A_{1}}{A_{2}}\right)^{\bar{\phi}}} \text { for station } 1 \text { to station } 2 \text { and } \\
{ }_{21} \kappa_{i}= & \frac{Q_{2 i}}{Q_{1 i}\left(\frac{A_{2}}{A_{1}}\right)^{\bar{\phi}}} \text { for station } 2 \text { to station } 1 .
\end{aligned}
$$




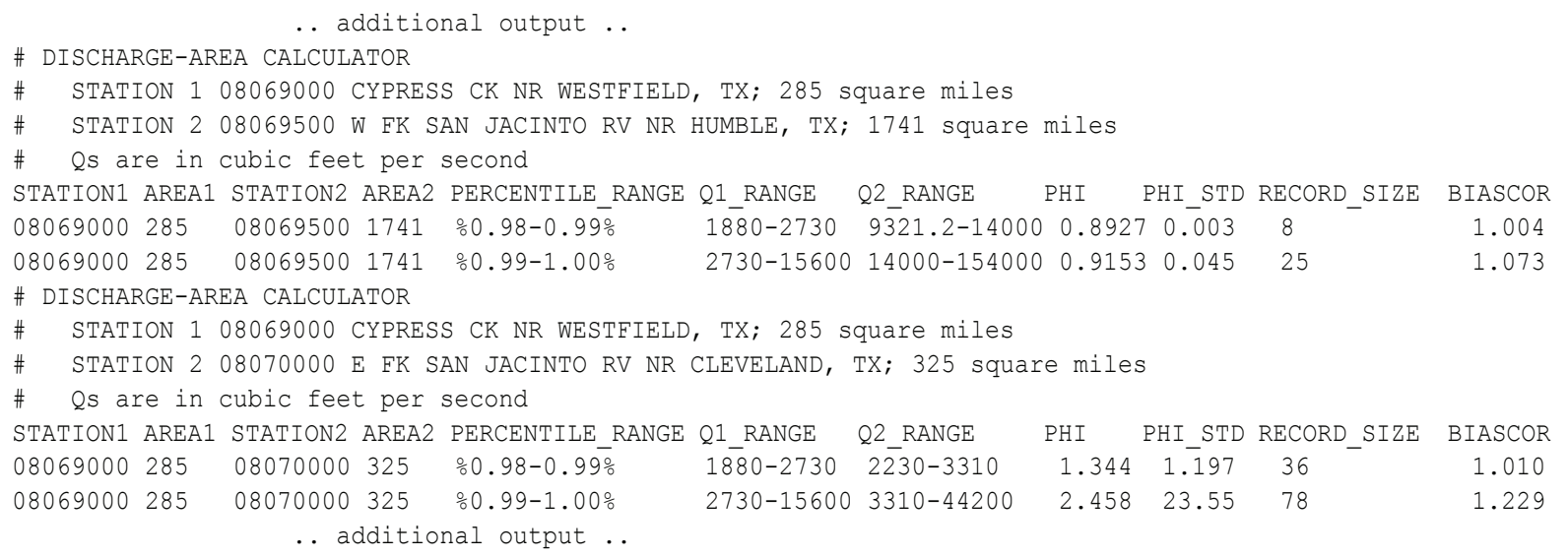

Figure 2. Example output from drainage-area ratio computation run for an arbitrary station pair and the 98-99 and $99-100$ percentile ranges.

The mean or expected value of the bias-correction factor is

$$
K=\frac{1}{2 n} \sum_{i=1}^{n}{ }_{12} \kappa_{i}+{ }_{21} \kappa_{i} .
$$

The corrections for bias with algebraic adjustment are known as "smearing estimates" (Duan, 1983; Helsel and Hirsch, 1992). Finally, equations 14 and 17 represent statistically estimated parameters of the generalized drainage-area ratio method.

\section{Example Calculations of Parameter Estimation}

To demonstrate how $\bar{\phi}$ and $K$ can be estimated from two streamflow-gaging stations, example calculations for four values of daily streamflow are listed in table 2. The notation [\#] refers to the vector of data values in the indicated column number. For example, a vector of the logarithms of column 2 is denoted as $\log ([2])$. Column 4 is computed by $\log ([2] /[3]) /$ $\log (839 / 10.9)$ where 839 and 10.9 are drainage areas for stations 1 and 2, respectively. The mean of column 4 is 0.9194 . Column 5 is computed by [3] $\times(839 / 10.9)^{0.9194}$; likewise column 6 is computed by [2] $\times(10.9 / 839)^{0.9194}$. Column 7 is computed by [2]/[5]; likewise column 8 is computed by [3]/[6]. The means of columns 7 and 8 are 1.987 and 1.442 for ${ }_{12} \bar{\kappa}$ and ${ }_{21} \bar{\kappa}$, respectively. The mean of these is $(1.987+1.442) / 2=$ 1.715. Thus, the generalized drainage-area ratio method for these two stations from the sample of 4 days is

$$
\frac{Q_{1}}{Q_{2}}=1.715\left(\frac{A_{1}}{A_{2}}\right)^{0.9194} .
$$

\section{Statewide Analysis of the Drainage-Area Ratio Method in Texas}

The daily mean streamflow data available for Texas constitute a very large data set from which $\phi$ and $K$ can be estimated to develop a framework by which the drainage-area ratio method can be implemented in Texas. To estimate the $\phi$ and $K$ parameters from a statewide perspective, the period-of-record streamflow and drainage areas for 712 stations were used. For each of the 34 streamflow percentile ranges, the streamflow for each of the 712 stations was compared to the streamflow for the remaining 711 stations. As a result, for each of the 34 percentile ranges, $253,116(712 \times 711 / 2)$ unique pairings of stations were made. Thus, 8,605,944 $(34 \times 253,116)$ pairings were considered. Given that the total number of daily values analyzed is in excess of 7.8 million, considerable computational resources were required ${ }^{2}$. Example output for an arbitrary station pair is shown in figure 2 .

The figure shows an abbreviated output pertinent to the investigation of the drainage-area ratio method. Each station pair is separated by a repetitive header (lines beginning with \#) and label line (lines beginning with STATION1). Within the output for each station pair, an ensemble of computations for the selected values of the percentile ranges of daily mean streamflow is present. For brevity, the figure only shows the 98-99 and 99-100 percentile ranges (PERCENTILE_RANGE). The Q1 RANGE and Q2 RANGE fields show the range in daily mean streamflow comprising the end points of the corresponding percentile range. The $\bar{\phi}$ value and its standard deviation are listed under the PHI and PHI_STD fields. The record size

\footnotetext{
${ }^{2}$ Just over a week of computer time using four computers and eight parallel processes was needed to complete a computation run. Four processes (two per computer) were run on a RedHat Linux WS4 $2 \times 2.0 \mathrm{GHz}$ Xeon CPU with 512MB memory and a MacOSX $10.42 \times 2.0 \mathrm{GHz}$ G5 CPU with 4GB memory, each equipped with two hard drives (one process per hard drive). The remaining four processes were run on a RedHat Linux $92 \times 2.2 \mathrm{GHz}$ Athlon CPU with $512 \mathrm{MB}$ memory and a SuSE Linux $9.1,2 \times 3.2 \mathrm{GHz}$ Xeon CPU, and 1GB memory computer. The aggregated output file for a computation run is about $1.96 \mathrm{~GB}$.
} 
Table 2. Example of parameter estimation for the generalized drainage-area ratio method.

[[\#], column number; $\mathrm{ft}^{3} / \mathrm{s}$, cubic feet per second; $\mathrm{mi}^{2}$, square miles]

\begin{tabular}{|c|c|c|c|c|c|c|c|}
\hline \multirow[t]{2}{*}{ Day } & \multicolumn{2}{|c|}{$\begin{array}{c}\text { Observed daily } \\
\text { mean streamflow } \\
\left(\mathrm{ft}^{3} / \mathrm{s}\right)\end{array}$} & \multirow{2}{*}{$\begin{array}{c}\text { Exponent } \\
\phi_{i}\end{array}$} & \multicolumn{2}{|c|}{$\begin{array}{c}\text { Estimated streamflow } \\
\text { without correction for bias } \\
\left(\mathrm{ft}^{3} / \mathrm{s}\right)\end{array}$} & \multicolumn{2}{|c|}{$\begin{array}{l}\text { Bias-correction } \\
\text { factors }\end{array}$} \\
\hline & $\begin{array}{l}\text { Station } 1 \\
\left(839 \mathrm{mi}^{2}\right)\end{array}$ & $\begin{array}{l}\text { Station } 2 \\
\left(10.9 \mathrm{mi}^{2}\right)\end{array}$ & & Station 1 & Station 2 & ${ }_{12} \kappa_{i}$ & ${ }_{21} \kappa_{i}$ \\
\hline [1] & [2] & [3] & [4] & [5] & [6] & [7] & [8] \\
\hline 1 & 1,470 & 4.3 & 1.343 & 233.2 & 27.10 & 6.304 & 0.1587 \\
\hline 2 & 158 & 4.3 & .8300 & 233.2 & 2.913 & .6775 & 1.476 \\
\hline 3 & 154 & 6.0 & .7471 & 325.4 & 2.839 & .4733 & 2.113 \\
\hline \multirow[t]{3}{*}{4} & 145 & 5.4 & .7575 & 292.9 & 2.673 & .4950 & 2.020 \\
\hline & & \multirow[t]{2}{*}{$\bar{\phi}$} & .9194 & & ${ }_{12} \bar{\kappa}$ and ${ }_{21} \bar{\kappa}$ & 1.987 & 1.442 \\
\hline & & & & \multicolumn{2}{|r|}{$K$} & \multicolumn{2}{|c|}{1.715} \\
\hline
\end{tabular}

(RECORD SIZE, total number of daily values processed) is listed next. The line terminates with $K$ (BIASCOR). The supporting values ${ }_{12} \bar{\kappa}$ and ${ }_{21} \bar{\kappa}$ are not listed. To clarify the contents of the output, the $\bar{\phi}$ value of 0.9153 for the station 08069000 to 08069500 comparison and the $99-100$ percentile range was computed from 25 same-day and same-percentile range daily streamflow values for the stations. In turn, the computed bias correction $(K)$ was 1.073 .

\section{Data Analysis}

Two types of analysis are performed on the database of $\bar{\phi}$ and $K$ (analogous to output shown in fig. 2). The first analysis uses the $\bar{\phi}$ and $K$ parameters for all applicable station pairs. The second analysis uses the $\bar{\phi}$ and $K$ parameters for station pairs conditional on separation distance between the stations and relative difference in drainage area. The term "applicable" means that at least five nonzero values for same-day streamflow and same streamflow percentile range for the two gaging stations were available for computation of $\bar{\phi}$ and $K$.

The first analysis style establishes a foundational perspective of the magnitude and variability of the two parameters in Texas. A statistical summary of the first analysis is listed in table 3. The table lists for each of the 34-streamflow percentile ranges the sample size (count of applicable station pairings) and the total number of daily values processed within the station pairings. The median and mean statistics of the mean $\bar{\phi}$ values are listed in the table; the standard deviation of the $\bar{\phi}$ values are listed as well. To clarify on the sample size, the mean $\phi$ listed in the table is the mean of the "sample size" number (column 2) of $\bar{\phi}$ values. The table also lists both the median, mean, and standard deviation statistics of the mean bias-correction factor $K$ values.
Several interpretations of values listed in table 3 are made. First, sample size increases with increase of absolute percentile. The primary reason is that zero values of daily streamflow are more likely for small percentiles than for large percentiles. Because the drainage-area ratio method is based in log-space, zero values are incompatible and thus particular station pairs are meaningless because of the presence of all zero values. Second, the means are much less than the medians suggesting a leftskewed distribution of $\phi$. Third, the standard deviation of $\phi$ is so large that the reliability of the mean or median $\phi$ values is questionable and further investigation is needed, which is provided through the second analysis.

The second analysis (hereafter referred to as the "conditional analysis") is based on the concept that as separation distance between the site of interest and the streamflow-gaging station increases the applicability of the drainage-area ratio method decreases. Conceptually, the applicability of the drainage-area ratio method diminishes as separation distance increases for reasons including (1) increasingly larger differences in hydrologic conditions, (2) increasingly larger differences in climate, and (3) increasingly larger differences in geology or other components of physiographic regions.

The relation between separation distance and mean $\bar{\phi}$ for the fourth quartile (75-100 percent range) of streamflow is shown in figure 3 . From the figure, the large variation in $\bar{\phi}$ values is seen, and the variation is consistent with the large standard deviation values listed in table 3. A cone-shape trend in $\bar{\phi}$ values is evident in which convergence (from right to left) towards a $\bar{\phi}$ value slightly less than 1 as separation distance decreases is seen. Because of the concept that stations which are increasingly far apart are expected to have diverging sameday hydrologic conditions, it is logical to limit analysis by separation distance. An upper limit of 100 miles was chosen. For distances greater than 100 miles, the variation in $\bar{\phi}$ rapidly becomes large. Similar relations between separation distance 


\section{Statewide Analysis of the Drainage-Area Ratio Method for 34 Streamflow Percentile Ranges in Texas}

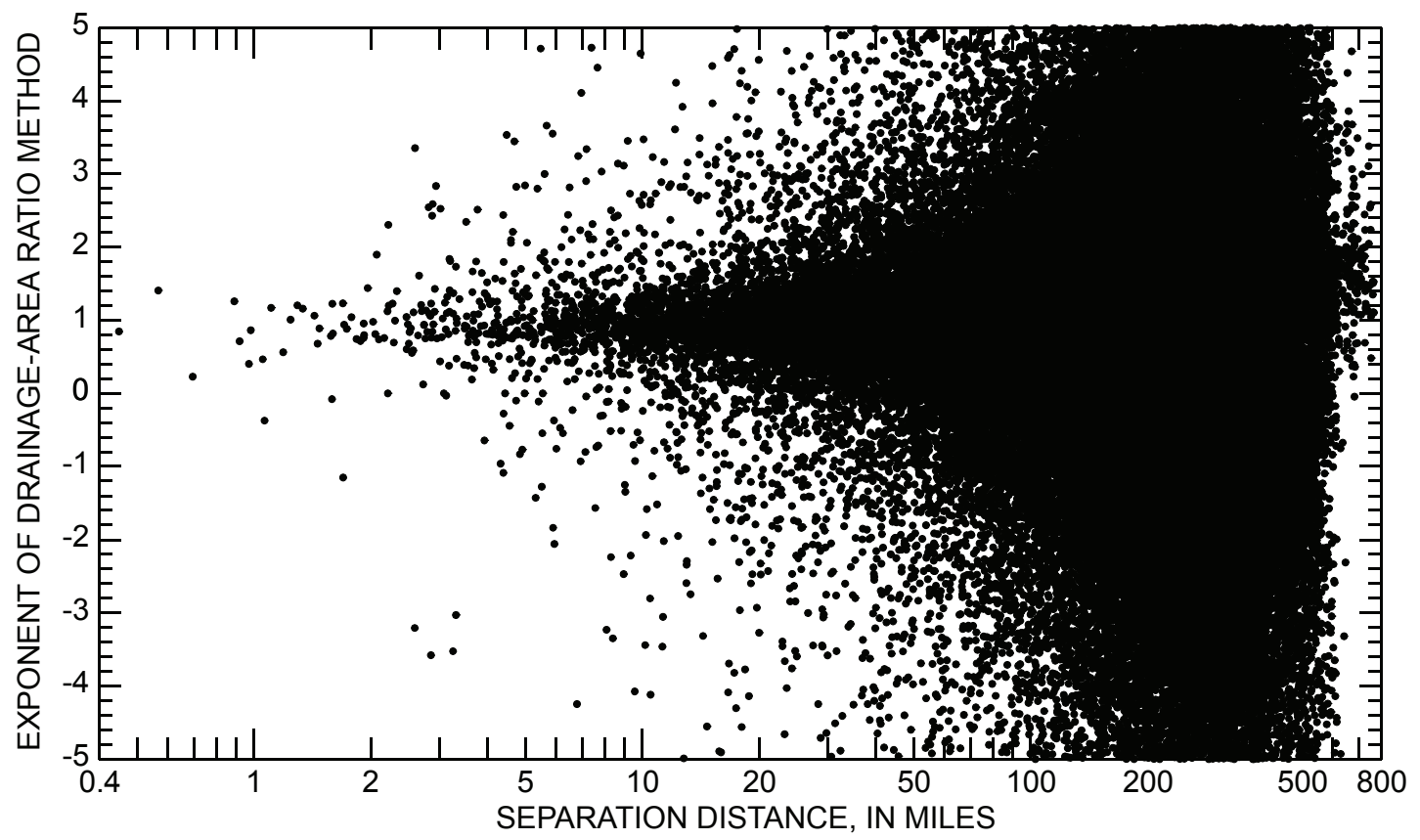

Figure 3. Relation between separation distance and exponent of drainage-area ratio method for the fourth quartile (75-100 percentile range) of daily streamflow in Texas.

and $\bar{\phi}$ for the other percentile ranges were evaluated (not presented in this report), and the conclusion consistently was made that 100 miles is an appropriate, albeit an ad hoc, upper limit.

Comparison of relative differences in drainage area to $\bar{\phi}$ values provides further insight into the relation between drainage area and $\bar{\phi}$. The relation between the relative difference in drainage area, measured by the absolute value of the logarithm (base-10) of the ratio of drainage areas, and the mean $\bar{\phi}$ for the fourth quartile (75-100 percent range) of streamflow is shown in figure 4 . The horizontal axis depicts the number of log cycles separating the two drainage areas. Instead of plotting all available station pairs, subselection or conditioning for stations with separation distance less than or equal to 100 miles was performed. As evident in the figure, there is large variation in $\bar{\phi}$ for similar magnitude drainage areas. A cone-shape trend in $\bar{\phi}$ values is evident in which convergence (from left to right) towards a $\bar{\phi}$ value slightly less than 1 is seen. A critical observation of the figure is that variation in $\bar{\phi}$ values rapidly reduces for drainage areas differing by more than about $0.25-\log$ cycles. The large variation in $\bar{\phi}$ as drainage areas become similar (identical) occurs because as the ratio of the drainage areas approaches 1 , $\bar{\phi}$ necessarily exhibits increasing sample variability because $\bar{\phi}$ often acquires large values to account for streamflow differences between the two stations. In other words

$$
\lim _{A_{1} \rightarrow A_{2}} \frac{A_{1}}{A_{2}}=1,
$$

so $\phi$ becomes increasingly arbitrary. Hence, in the spirit of increasing the reliability of statistical estimation, the following relative drainage area criteria was established for the conditional analysis

$$
0.25 \leq\left|\log \left(\frac{A_{1}}{A_{2}}\right)\right| .
$$

Because of the smooth convergence of $\phi$ from left to right in figure 4, no upper limit to relative drainage area difference is established.

The separation distance and relative drainage-area criteria were developed in an iterative, but still ad hoc, fashion through exploratory data analysis culminating with interpretations of graphs such as those shown in figures 3 and 4 . The reliability of statistical estimates of $\phi$ and $K$ is increased by conditioning the station pairs and using the two criteria.

A statistical summary of the conditional analysis is listed in table 4, which lists for each of the 34 percentile ranges the sample size (count of applicable station pairings) and the total number of daily values processed within the station pairings.

The median, mean, and standard deviation statistics of the mean $\bar{\phi}$ values are listed in the table. To clarify on the sample size, the mean $\phi$ listed in the table is the mean of the "sample size" number (column 2) of $\bar{\phi}$ values. The table also lists both the median and mean statistics of the mean bias-correction factor $K$ values; the standard deviations of the $K$ values are listed as well.

Comparison of the statistics listed in table 4 to corresponding values in table 3 indicates that mean and median values are considerably closer in magnitude after the separation distance and relative drainage-area criteria are applied. The median 
Table 3. Summary statistics of drainage-area ratio method for each of the 34 percentile ranges of streamflow in Texas.

\begin{tabular}{|c|c|c|c|c|c|c|c|c|}
\hline \multirow{2}{*}{$\begin{array}{c}\text { Streamflow } \\
\text { percentile } \\
\text { range }\end{array}$} & \multirow{2}{*}{$\begin{array}{l}\text { Sample size } \\
\text { (count of } \\
\text { applicable } \\
\text { station } \\
\text { pairs) }\end{array}$} & \multirow{2}{*}{$\begin{array}{l}\text { Total number } \\
\text { of daily } \\
\text { values } \\
\text { processed }\end{array}$} & \multicolumn{3}{|c|}{ Exponent $\phi$} & \multicolumn{3}{|c|}{ Bias-correction factor $K$} \\
\hline & & & Median & Mean & $\begin{array}{l}\text { Standard } \\
\text { deviation }\end{array}$ & Median & Mean & $\begin{array}{l}\text { Standard } \\
\text { deviation }\end{array}$ \\
\hline \multicolumn{9}{|l|}{ Quartiles } \\
\hline $0-25$ & 105,614 & $53,644,385$ & 0.790 & 0.490 & 48.4 & 1.84 & 2.53 & 2.45 \\
\hline $25-50$ & 144,138 & $72,076,225$ & .808 & .703 & 49.2 & 1.15 & 1.35 & .628 \\
\hline $50-75$ & 163,891 & $79,607,258$ & .821 & .760 & 37.7 & 1.14 & 1.33 & .824 \\
\hline $75-100$ & 183,644 & $124,502,596$ & .786 & .662 & 41.9 & 2.98 & 8.18 & 72.8 \\
\hline \multicolumn{9}{|l|}{ Lower tail } \\
\hline $0-1$ & 6,884 & 120,393 & .720 & 1.68 & 57.5 & 1.03 & 1.16 & .417 \\
\hline $1-2$ & 11,854 & 93,906 & .766 & .535 & 65.6 & 1.00 & 1.04 & .122 \\
\hline $2-3$ & 16,017 & 94,744 & .805 & .0971 & 62.9 & 1.00 & 1.03 & .125 \\
\hline $3-4$ & 19,712 & 99,315 & .859 & .320 & 64.8 & 1.00 & 1.01 & .0667 \\
\hline $4-5$ & 22,875 & 104,709 & .830 & .700 & 35.8 & 1.00 & 1.01 & .0557 \\
\hline \multicolumn{9}{|c|}{ Quintiles of first quartile } \\
\hline $0-5$ & 37,700 & $2,340,594$ & .777 & .252 & 58.9 & 1.17 & 1.50 & 1.02 \\
\hline $5-10$ & 57,338 & $2,330,925$ & .808 & .366 & 45.0 & 1.03 & 1.12 & .277 \\
\hline $10-15$ & 73,479 & $2,353,238$ & .812 & .484 & 45.2 & 1.01 & 1.07 & .203 \\
\hline $15-20$ & 86,781 & $2,544,805$ & .811 & .388 & 52.1 & 1.01 & 1.04 & .119 \\
\hline $20-25$ & 95,643 & $2,635,428$ & .807 & .570 & 44.6 & 1.01 & 1.03 & .0955 \\
\hline \multicolumn{9}{|c|}{ Quintiles of second quartile } \\
\hline $25-30$ & 105,248 & $2,688,949$ & .810 & .589 & 39.4 & 1.00 & 1.02 & .0636 \\
\hline $30-35$ & 115,631 & $2,928,715$ & .829 & .657 & 45.5 & 1.00 & 1.02 & .0425 \\
\hline $35-40$ & 123,501 & $3,012,915$ & .815 & .778 & 39.0 & 1.00 & 1.02 & .133 \\
\hline $40-45$ & 125,596 & $3,038,213$ & .796 & .767 & 36.3 & 1.00 & 1.01 & .0356 \\
\hline $45-50$ & 131,185 & $3,126,384$ & .809 & .712 & 38.9 & 1.00 & 1.01 & .033 \\
\hline \multicolumn{9}{|c|}{ Quintiles of third quartile } \\
\hline $50-55$ & 133,017 & $3,131,395$ & .802 & .752 & 39.8 & 1.00 & 1.01 & .0486 \\
\hline $55-60$ & 138,695 & $3,211,017$ & .809 & .831 & 37.5 & 1.00 & 1.01 & .0226 \\
\hline $60-65$ & 142,796 & $3,190,527$ & .810 & .728 & 38.8 & 1.00 & 1.02 & .109 \\
\hline $65-70$ & 145,964 & $3,420,121$ & .812 & .698 & 37.8 & 1.00 & 1.02 & .0906 \\
\hline $70-75$ & 152,138 & $3,602,955$ & .818 & .797 & 36.4 & 1.01 & 1.02 & .0640 \\
\hline \multicolumn{9}{|c|}{ Quintiles of fourth quartile } \\
\hline $75-80$ & 155,744 & $3,979,760$ & .820 & .772 & 42.5 & 1.01 & 1.01 & .026 \\
\hline $80-85$ & 158,048 & $4,390,667$ & .822 & .772 & 35.6 & 1.01 & 1.04 & .150 \\
\hline $85-90$ & 163,889 & $5,150,742$ & .819 & .728 & 38.6 & 1.02 & 1.04 & .117 \\
\hline $90-95$ & 168,848 & $6,438,618$ & .786 & .663 & 42.2 & 1.05 & 1.08 & .166 \\
\hline 95-100 & 173,571 & $11,335,377$ & .694 & .608 & 37.9 & 1.61 & 2.45 & 10.2 \\
\hline \multicolumn{9}{|l|}{ Upper tail } \\
\hline $95-96$ & 105,722 & 330,178 & .761 & .848 & 29.7 & 1.00 & 1.00 & .0162 \\
\hline $96-97$ & 108,936 & 371,788 & .738 & .761 & 28.1 & 1.00 & 1.01 & .0251 \\
\hline $97-98$ & 114,679 & 449,496 & .716 & .615 & 28.6 & 1.00 & 1.01 & .0361 \\
\hline 98-99 & 118,510 & 574,368 & .687 & .587 & 38.1 & 1.01 & 1.02 & .0593 \\
\hline 99-100 & 120,641 & 1,034048 & .643 & .596 & 18.0 & 1.13 & 1.27 & .481 \\
\hline
\end{tabular}




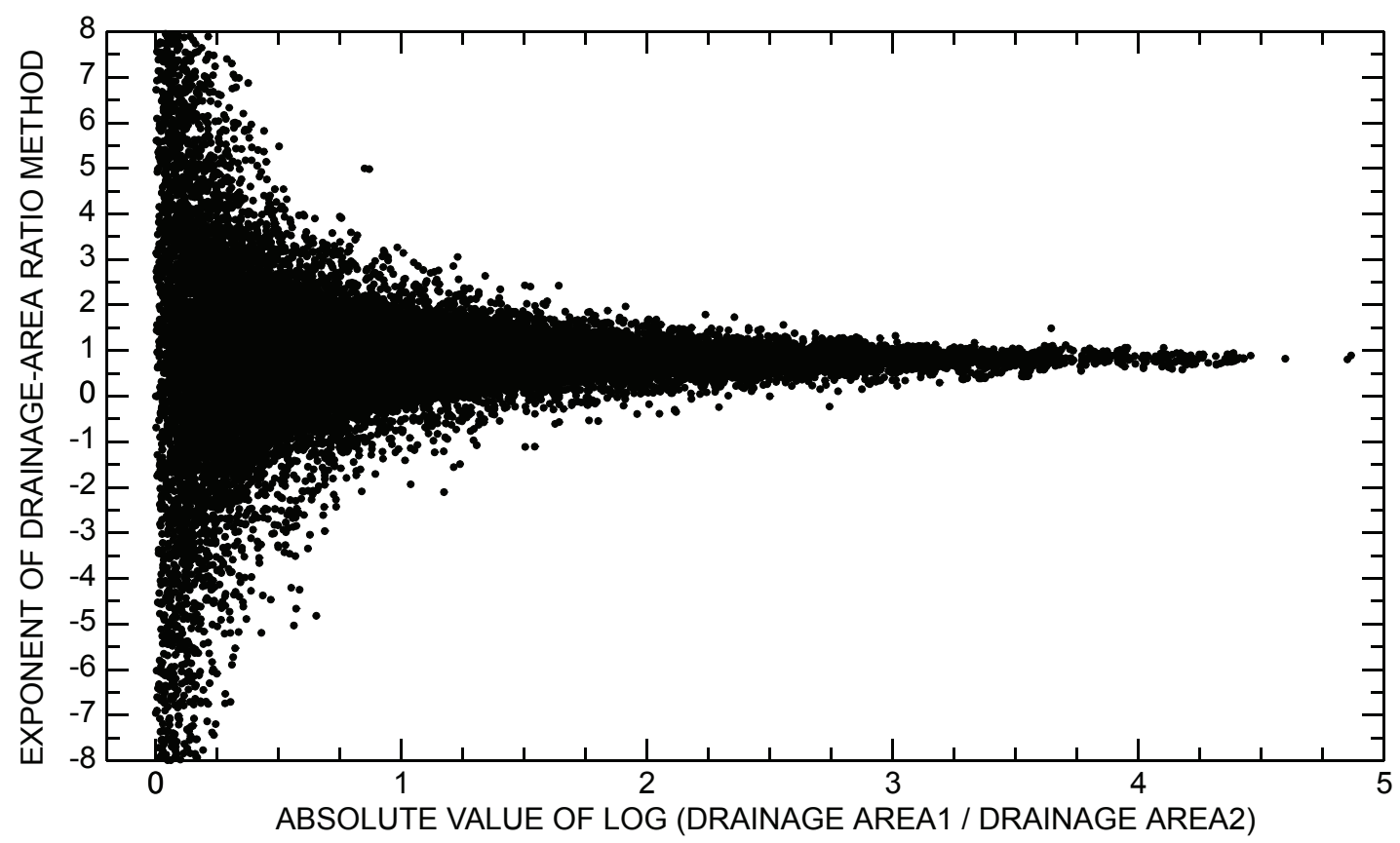

Figure 4. Relation between absolute value of logarithm of ratio of drainage areas and exponent of drainage-area ratio method for fourth quartile (75-100 percentile range) of daily streamflow in Texas for station pairs with separation distance less than or equal to 100 miles.

remains slightly larger than the mean; however, a more symmetrical distribution of $\phi$ is evident. The standard deviations are dramatically smaller after the criteria are applied. Hence, more reliable characterization of $\phi$ and $K$ is made.

A graphical depiction of the mean $\phi$ values listed in table 4 is shown in figure 5. In this figure, the general value of about 0.9 is seen except for the very largest streamflow percentiles. For the largest streamflow percentiles, $\phi$ decreases substantially to about 0.7 . The trend is consistent with $\phi$ acquiring a value of about 0.5 for annual peak (instantaneous) streamflow in Texas (Asquith and Thompson, 2005). Annual peak streamflow values are generally larger than most daily mean streamflow values and hence corresponding $\phi$ values are in the region near and "beyond" the right-most portion of the horizontal axis. The smoothed relation between $\phi$ and streamflow percentile shown in the figure is discussed in section "Implementation of the Drainage-Area Ratio Method in Texas."

The bias-correction factor is about 1.00-1.01 for most percentile ranges. A graphical depiction of the mean $K$ values listed in table 4 is shown in figure 6 , wherein a "U" shape to $K$ is evident for the quartiles and the 5-percent-wide intervals. A similar U-shape, although subtle, is evident if the lower and upper tails are considered together. In general, $K$ increases into the tails of the streamflow distribution for a given width of percentile interval. For example, observe how $K$ values for the 0 25 and $75-100$ percentile range are larger than the nearly equal values for the $25-50$ percentile and 50-75 percentile range. Further, the largest $K$ values are seen when the interval of analysis is large. For example, the $75-100$ percentile range is larger than the 75-80 percentile range. As the interval becomes small (for example, the $97-98$ percentile range), the bias of the drainagearea ratio method becomes small.

The authors make an explicit interpretation that the bias correction is about unity as the interval of analysis becomes small. This conclusion is strongly supported by the biases observed for the 5-percent-wide intervals (grey circles, exclusive of the lower and upper 10th percentiles on fig. 6) and augmented by the 1-percent-wide lower and upper tails (see open circles on fig. 6). The authors conclude, therefore, that the drainage-area ratio method is either inherently unbiased or the bias is less than 1 or 2 percent when a suitably narrow region of the flow-duration curve is analyzed. No mathematical proof for this conclusion is made; however, the authors speculate that the bias is exhibited computationally because the typical daily mean streamflow distribution exhibits considerable curvilinearity in both the lower and upper quartiles. If the interval of analysis is large and the interval is in the tails of the distribution, the curvilinearity produces the bias.

\section{Implementation of the Drainage-Area Ratio Method in Texas}

Additional interpretation and refinement of the analysis results for implementation of the drainage-area ratio method for daily mean streamflow estimation in Texas is made.

1. The analysis strongly indicates that same-day and same-percentile streamflow does not scale by per-unit drainage area basis $(\phi=1)$ but instead scales according to a fractional power of drainage area $(\phi<1)$. The 
Table 4. Summary statistics of drainage-area ratio method conditional on separation distance and relative drainage area for each of the 34 percentile ranges of streamflow in Texas.

[Separation distance between station pairs was less than or equal to 100 miles; the absolute value of the logarithm of the ratio of the drainage area was greater than or equal to 0.25 ]

\begin{tabular}{|c|c|c|c|c|c|c|c|c|}
\hline $\begin{array}{l}\text { Streamflow } \\
\text { percentile } \\
\text { range }\end{array}$ & $\begin{array}{l}\text { Sample size } \\
\text { (count of } \\
\text { applicable } \\
\text { station pairs) }\end{array}$ & $\begin{array}{l}\text { Total number } \\
\text { of daily } \\
\text { values } \\
\text { processed }\end{array}$ & \multicolumn{3}{|c|}{ Exponent $\phi$} & \multicolumn{3}{|c|}{ Bias-correction factor $K$} \\
\hline \multicolumn{9}{|l|}{ Quartiles } \\
\hline $0-25$ & 15,521 & $9,266,530$ & 0.952 & 0.876 & 1.78 & 1.72 & 2.30 & 2.17 \\
\hline $25-50$ & 20,409 & $11,554,604$ & .941 & .886 & 1.61 & 1.13 & 1.31 & .496 \\
\hline $75-100$ & 24,584 & $21,617,656$ & .883 & .874 & .856 & 2.38 & 4.99 & 22.72 \\
\hline \multicolumn{9}{|l|}{ Lower Tail } \\
\hline $0-1$ & 1,386 & 32,339 & .824 & .829 & 1.76 & 1.03 & 1.16 & .410 \\
\hline $1-2$ & 2,278 & 22,065 & .902 & .908 & 1.76 & 1.00 & 1.03 & .103 \\
\hline $2-3$ & 2,883 & 20,199 & .920 & .916 & 1.83 & 1.00 & 1.03 & .101 \\
\hline $0-5$ & 6,137 & 500,060 & .919 & .875 & 1.91 & 1.17 & 1.50 & 1.08 \\
\hline $5-10$ & 8,735 & 445,235 & .948 & .888 & 1.81 & 1.03 & 1.11 & .242 \\
\hline $10-15$ & 10,921 & 425,884 & .958 & .898 & 1.81 & 1.01 & 1.06 & .175 \\
\hline $15-20$ & 12,780 & 440,074 & .957 & .902 & 1.77 & 1.01 & 1.04 & .0934 \\
\hline $20-25$ & 14,182 & 452,190 & .940 & .895 & 1.64 & 1.01 & 1.03 & .0958 \\
\hline \multicolumn{9}{|c|}{ Quintiles of second quartile } \\
\hline $25-30$ & 15,550 & 455,011 & .930 & .871 & 1.68 & 1.00 & 1.02 & .0712 \\
\hline $30-35$ & 16,829 & 482,096 & .951 & .910 & 1.62 & 1.00 & 1.02 & .0357 \\
\hline $35-40$ & 17,818 & 491,931 & .947 & .908 & 1.58 & 1.00 & 1.02 & .0882 \\
\hline $65-70$ & 20,479 & 554,689 & .938 & .934 & 1.22 & 1.00 & 1.02 & .0838 \\
\hline $70-75$ & 21,326 & 591,767 & .936 & .935 & 1.16 & 1.01 & 1.01 & .0539 \\
\hline \multicolumn{9}{|c|}{ Quintiles of fourth quartile } \\
\hline $75-80$ & 21,763 & 669,295 & .932 & .933 & 1.10 & 1.01 & 1.01 & .0257 \\
\hline $80-85$ & 22,122 & 769,374 & .930 & .933 & 1.02 & 1.01 & 1.02 & .0993 \\
\hline $85-90$ & 22,831 & 947,795 & .920 & .925 & .990 & 1.02 & 1.04 & .117 \\
\hline $90-95$ & 23,264 & $1,285,919$ & .880 & .886 & .979 & 1.05 & 1.07 & .138 \\
\hline 95-100 & 23,747 & $2,627,616$ & .757 & .768 & .677 & 1.52 & 2.01 & 3.33 \\
\hline \multicolumn{9}{|l|}{ Upper tail } \\
\hline $95-96$ & 16,723 & 72,330 & .828 & .850 & .826 & 1.00 & 1.00 & .0175 \\
\hline $96-97$ & 17,342 & 84,083 & .804 & .819 & .777 & 1.00 & 1.01 & .0227 \\
\hline 97-98 & 18,091 & 105,355 & .781 & .802 & .692 & 1.01 & 1.01 & .0180 \\
\hline 98-99 & 18,755 & 144,517 & .747 & .765 & .617 & 1.01 & 1.02 & .0346 \\
\hline 99-100 & 20,203 & 322,824 & .693 & .702 & .566 & 1.19 & 1.31 & .540 \\
\hline
\end{tabular}




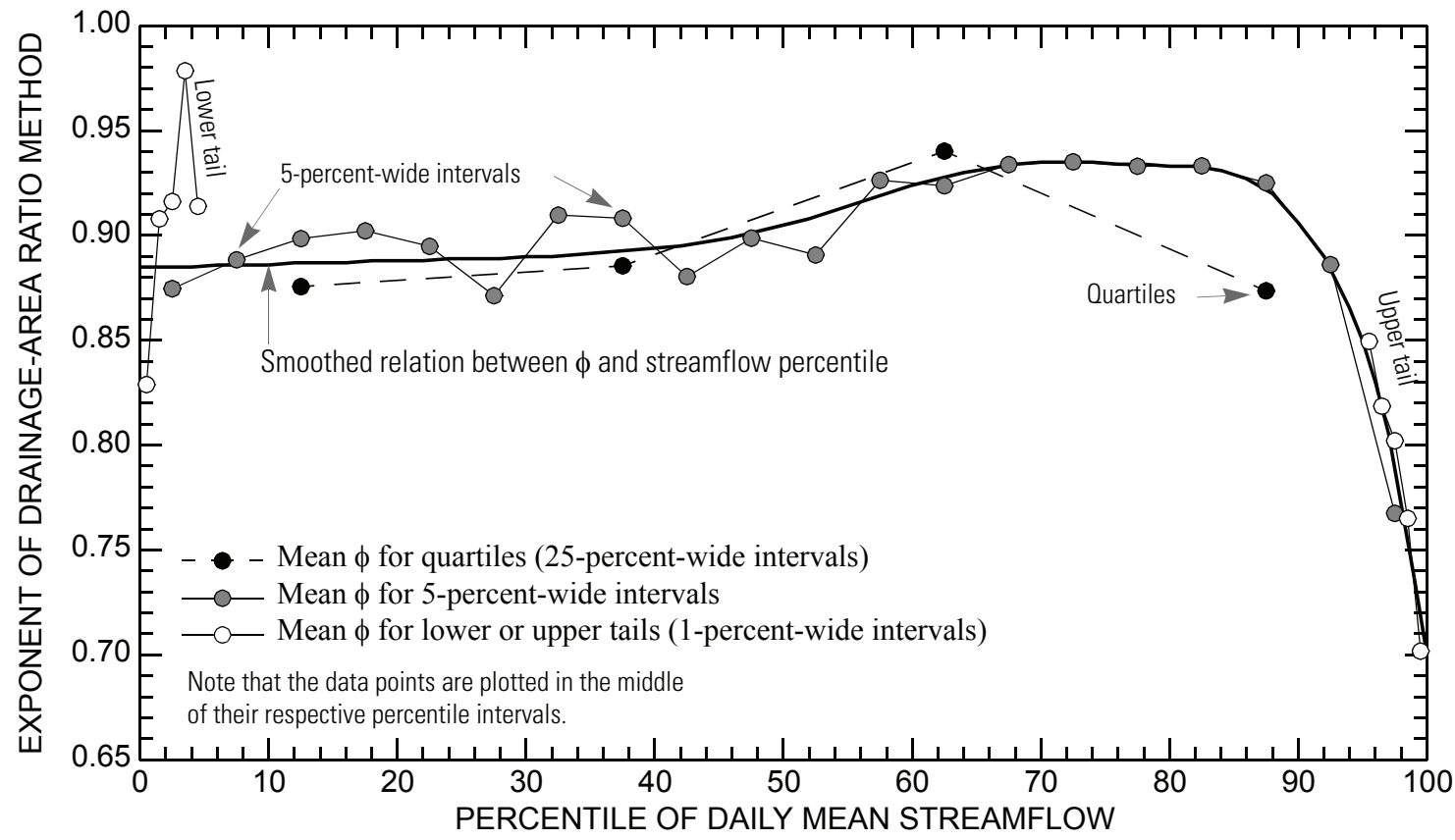

Figure 5. Relation between conditional exponents $(\phi)$ of drainage-area ratio method and percentile of daily mean streamflow in Texas by streamflow-frequency width interval.

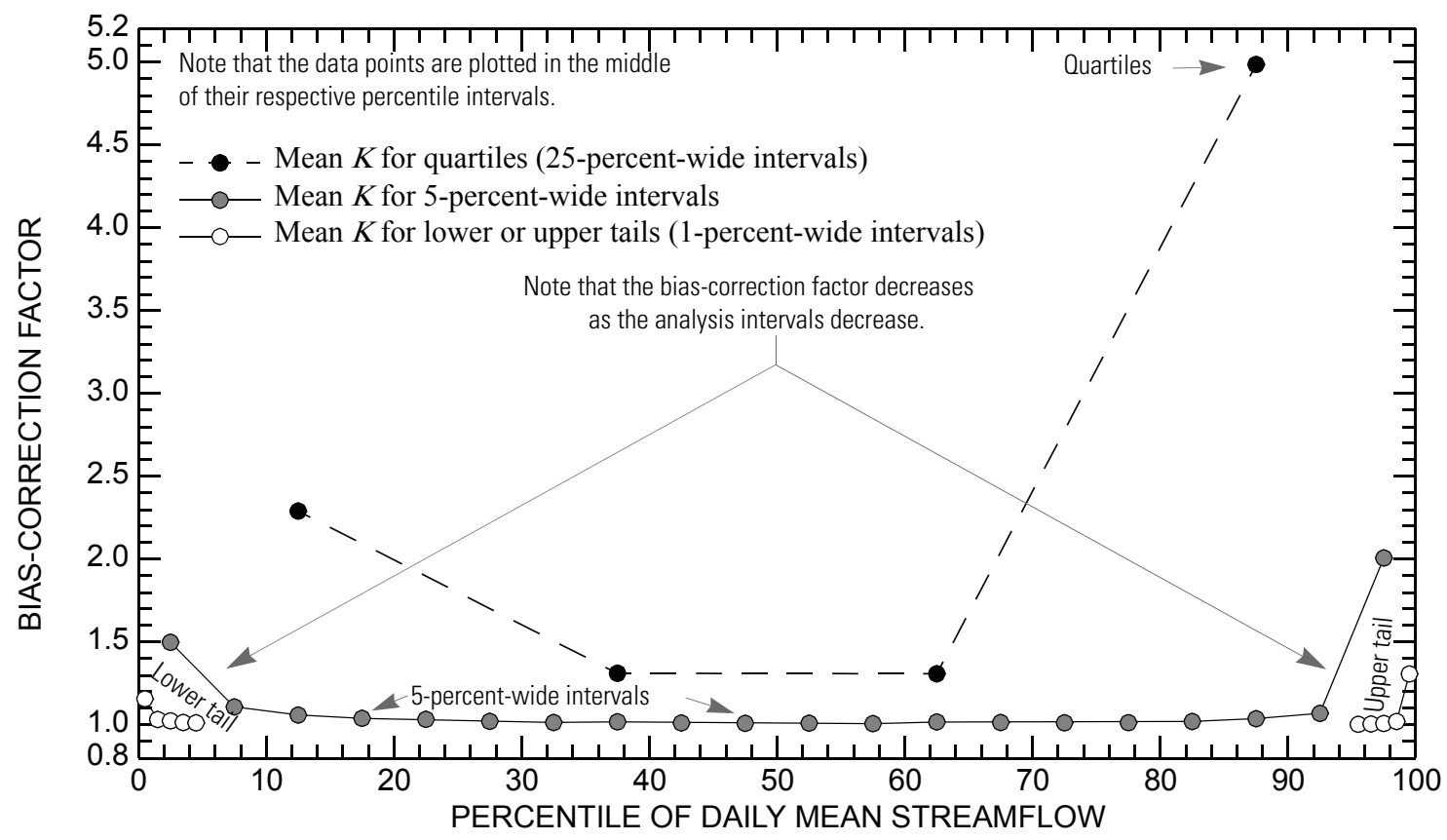

Figure 6. Relation between conditional bias-correction factors $(\kappa)$ of drainage-area ratio method and percentile of daily mean streamflow in Texas by streamflow-frequency width interval.

precise value of $\phi$ is a function of streamflow percentile (probability).

2. The authors explicitly conclude that the quartiles of streamflow are too wide for reliable estimation of both values for $\phi$ or $K$ and that the 5-percent-wide intervals are too wide for the lower and upper 10th percentiles of streamflow.

3. More specific interpretations of $\phi$ values in figure 5 and table 4 are possible. Values for $\phi$ are about 0.89 for streamflow percentiles from 0 to about 50 percent, are 
Table 5. Suggested exponents for the drainage-area ratio method in Texas.

\begin{tabular}{cccccccc}
\hline $\begin{array}{c}\text { Streamflow } \\
\text { percentile }\end{array}$ & Exponent $\phi$ & $\begin{array}{c}\text { Streamflow } \\
\text { percentile }\end{array}$ & Exponent $\phi$ & $\begin{array}{c}\text { Streamflow } \\
\text { percentile }\end{array}$ & Exponent $\phi$ & $\begin{array}{c}\text { Streamflow } \\
\text { percentile }\end{array}$ & Exponent $\phi$ \\
\hline 0 & 0.885 & 28 & .889 & 56 & .916 & 84 & .931 \\
2 & .885 & 30 & .890 & 58 & .920 & 86 & .927 \\
4 & .885 & 32 & .890 & 60 & .924 & 88 & .920 \\
6 & .886 & 34 & .891 & 62 & .927 & 90 & .906 \\
8 & .886 & 36 & .892 & 64 & .930 & 92 & .890 \\
10 & .886 & 38 & .893 & 66 & .932 & 94 & .865 \\
12 & .887 & 40 & .894 & 68 & .934 & 95 & .850 \\
14 & .887 & 42 & .895 & 70 & .935 & 96 & .830 \\
16 & .887 & 44 & .897 & 72 & .935 & 97 & .806 \\
18 & .888 & 46 & .899 & 74 & .935 & 98 & .773 \\
20 & .888 & 48 & .902 & 76 & .934 & 99 & .737 \\
22 & .888 & 50 & .905 & 78 & .934 & 100 & .700 \\
24 & .889 & 52 & .908 & 80 & .933 & & \\
26 & .889 & 54 & .912 & 82 & .933 & & \\
\hline
\end{tabular}

about 0.92 for percentiles from about 50 to about 65 percent, and are about 0.93 for percentiles from about 65 to about 85 percent. The exponent decreases rapidly to about 0.70 for percentiles nearing 100 percent. The authors conclude by intuition and observation that $\phi$ smoothly varies throughout the flow-duration curve. A smoothed relation between $\phi$ and streamflow percentile is depicted in figure 5, and the smoothed values are listed in table 5. These smoothed values were graphically determined. The lower tail data points (open circles, fig. 5) were not used because of the markedly smaller sample sizes relative to the 5-percent-wide interval and the upper tail data points. The smoothed relation is suggested for implementation of the drainage-area ratio method for daily mean streamflow values in Texas.

4. The variability of $\phi$ is considerable as evidenced by the large standard deviation values listed in tables 3 and 4. Coefficients of variation are often near 1.5 (coefficient of variation equals the standard deviation divided by the mean). There is considerable uncertainty in $\phi$, but the central tendency of $\phi$ is well established in this report. Further, it is important to consider that streamflow exhibits much variation in time and space; therefore, use of the $\phi$ with more than two decimal places likely implies precision intrinsically not present in the drainagearea ratio method.

The drainage-area ratio method is straightforward to use. For example, suppose the ungaged location has a drainage area of 45 square miles and a nearby streamflow-gaging station is operational and has a drainage area of 450 square miles. The streamflow at the gaging station is 62 cubic feet per second.
From the flow-duration curve for the station, 62 cubic feet per second is approximately the $33 \mathrm{rd}$ percentile of streamflow. The appropriate $\phi$ value (table 5) is 0.89 and the bias-correction factor is 1 . The same-day streamflow for the ungaged location is assumed to be at the 33rd percentile streamflow; therefore, the magnitude of the flow is

$$
\widehat{Q}_{1}=62 \times 1\left(\frac{45}{450}\right)^{0.89}=8.0 \text { cubic feet per second } .
$$

An inherent complication in use of the drainage-area ratio method for specific ungaged locations is that two or more hydrologically similar streamflow-gaging stations satisfying the 100-mile maximum separation distance criteria could be used. Development of a hierarchal or decision tree to decide which candidate stations should be used is difficult, and judgment on the part of the analyst on the basis of hydrologic familiarity with the watersheds in question is required.

There are several concepts to consider when evaluating stations for use in the drainage-area ratio method: (1) Degree of watershed development-comparison of undeveloped to undeveloped or similarly developed watersheds is more favorable than comparison of a highly regulated watershed to an undeveloped watershed or a comparison of an urban watershed to a highly regulated watershed. (2) Soil types, vegetation, and geologic setting - comparison of watersheds having similar soil type, vegetation, and geologic setting are more favorable.

(3) Water use characteristics-return and diversion flows complicate application of the drainage-area ratio method. As evidenced by this list, many caveats exist and numerous judgments must be made with site-specific application of the drainage-area ratio method. 


\section{Statewide Analysis of the Drainage-Area Ratio Method for 34 Streamflow Percentile Ranges in Texas}

In practice, if the analyst decides that multiple stations are applicable, then the authors suggest that the arithmetic mean of the estimated streamflow for all appropriate stations be used. However, the median might be preferable to some analysts. For example, if three stations are deemed applicable to an ungaged location, three estimates of streamflow for the ungaged location would result from application of the method. The mean or median of the three estimates for the ungaged location would be preferable. An example of the method with multiple applicable stations available is provided in figure 7.

\section{Sensitivity of the Drainage-Area Ratio Method}

The sensitivity of the drainage-area ratio method to $\phi$ is informative. Because $\phi$ is an exponent in the method, estimated flows are particularly sensitive to the value of $\phi$. Viewing equation 10 as a function of $\phi$ and differentiating with respect to $\phi$ produces

$$
\frac{d \widehat{Q_{1}}}{d \phi}=K Q_{2} \ln \left(\frac{A_{1}}{A_{2}}\right)\left(\frac{A_{1}}{A_{2}}\right)^{\phi},
$$

where all variables are defined as in equation 10 . The derivative shows that the estimated streamflow changes (left-hand side of equation 22) proportionally to the " $\phi$-power" of the drainagearea ratio (right-hand side of equation 22). The derivative implies that a linear variation in $\phi$ exponentially affects streamflow. To illustrate, increasing $\phi$ to 1 from 0.89 (used in the previous example) increases $\phi$ by 12 percent [(1-0.89)/0.89]; however, the estimated streamflow changes from 8.0 to 6.2 cubic feet per second, which is a 22-percent decrease. Conversely, decreasing $\phi$ to 0.8 from 0.89 decreases $\phi$ by 10 percent [(0.80-0.89)/0.89]; however the estimated streamflow changes from 8.0 to 9.83 cubic feet per second, which is a 23 percent increase.

For the illustration chosen here, increases in $\phi$ correspond to decreases in estimated streamflow because the drainagearea ratio $\left(A_{1} / A_{2}=45 / 450\right)$ is less than 1 and the factor $\ln \left(A_{1} / A_{2}\right)$ in equation 22 is less than 0 , which results in an overall negative rate of change (derivative). Otherwise, increases of estimated streamflow would occur with increasing $\phi$ when the drainage-area ratio is more than 1 . In summary, the derivative of the drainage-area ratio method shows that substantial underestimation or overestimation of streamflow can occur with apparently minor changes in $\phi$. The suggested values of $\phi$ listed in table 5 should, therefore, be used instead of $\phi=1$. Finally, as depicted in figure 5, $\phi$ changes most rapidly for large percentiles so sensitivity of streamflow estimates with $\phi$ is greatest for large magnitude streamflow. The applicability of the method is dependent on the hydrologic similarity between the two sites. For example, similar drainage area, slope, climate, and hydrologic response of the watersheds increases the likelihood of reliably estimating discharge at an ungaged location using the drainage-area ratio method.

\section{Limitations of the Drainage-Area Ratio Method}

Following is a list of enumerated limitations of the drainage-area ratio method:

1. The analysis is based on daily mean streamflow. The reliability of the method for other streamflow durations (monthly or annual mean streamflow) or classifications (annual peak streamflow) is uncertain or inappropriate, respectively. For example, use of the method for the 7Q2, often a regulatory critical low flow condition, is appropriate because the 7Q2 is derived from daily streamflow values. Conversely, the method would not be appropriate for peak streamflow values as they are not derived from daily streamflow values.

2. In general, for continuous daily mean streamflow-gaging stations the USGS reports 0.01 cubic foot per second as the smallest nonzero daily mean streamflow value. Lacking the contribution of additional information for application of the method or alternative techniques at a given ungaged location, it is uncertain how the method performs for streamflow estimation at values less than 0.01 cubic foot per second. Users might consider setting an estimate to zero if the method predicts less than 0.01 cubic foot per second. The authors explicitly recognize, however, that such a practice might not be suitable for universal application.

3. Other factors being equal, small separation distances between the ungaged location and the streamflow-gaging station are preferable to large separation distances.

4. To increase the reliability of summary statistics, the minimum absolute value of the logarithm of the drainage-area ratio was $0.25-\log$ cycles. This criteria is used because much uncertainty in estimation of $\phi$ from data exists when the drainage areas are similar. For application, however, the minimum drainage-area ratio should not be used. Specifically, similar or exactly equal watershed areas for nearby stations are expected to be most appropriate. For example, if the two drainage areas are equal then the drainage-area ratio method equates the streamflow for the ungaged site to the streamflow for the gaging station.

5. Contrary to our expectation, selection of an upper bound of drainage-area ratio is not made or used in data processing; however, relatively large differences in drainage area imply differences in daily mean streamflow during storm events (large magnitude events) because of differences in lag or response time of the watersheds. It is suggested that drainage-area difference greater than about $1.5-\log$ cycles be cautiously used. This criteria is used in common practice for daily streamflow statistics (Reis and Friez, 2000; Hortness, 2006) and peak streamflow statistics (Kjelstrom, 1998; Berenbrock, 2002; Parrett and Johnson, 2004). 


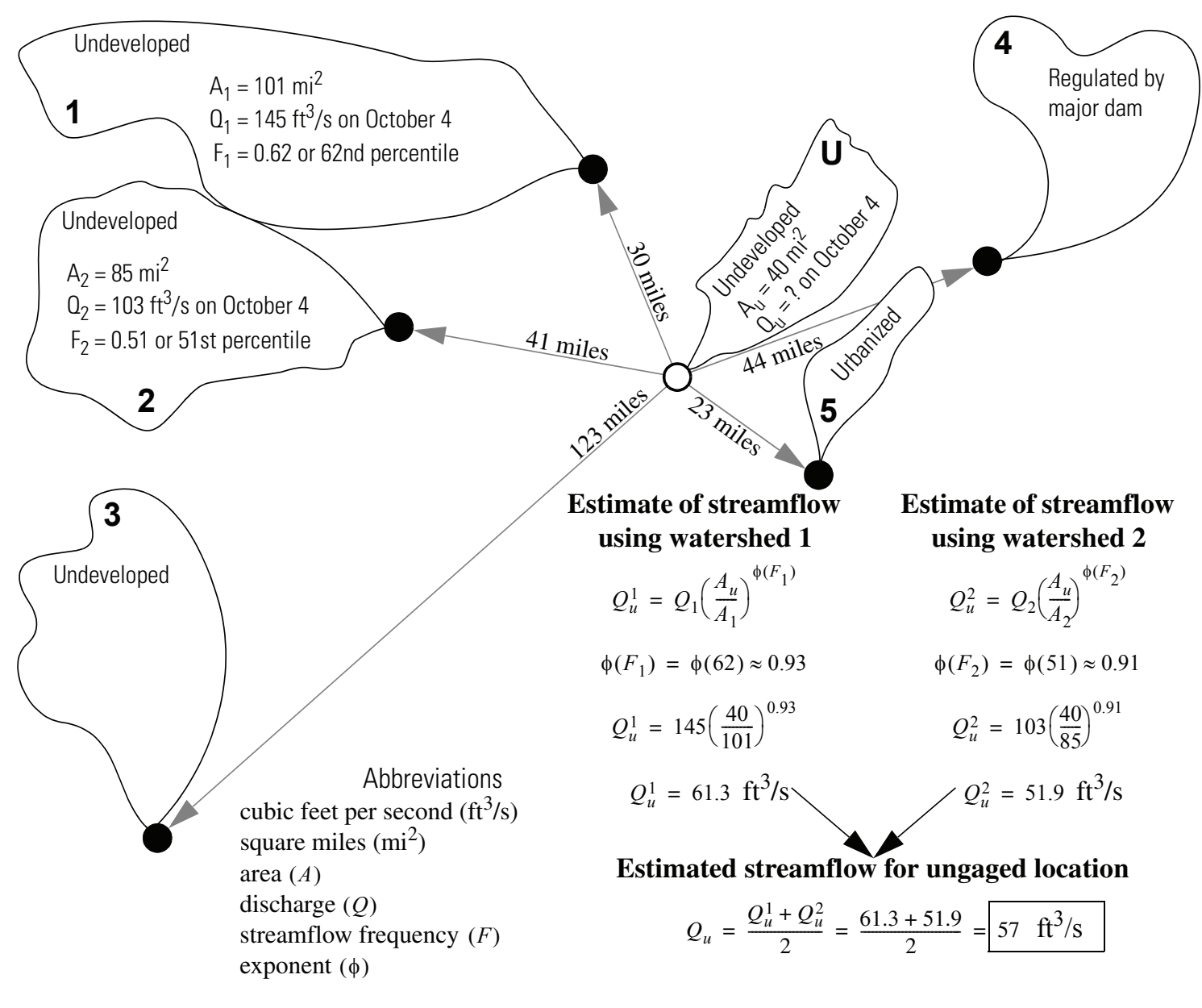

Figure 7. Example application of the drainage-area ratio method.

6. The preferred investigation of the drainage-area ratio method considered a maximum of 100-mile separation distance between stations; hence, it is suggested that users of the method presented here limit the distance between the streamflow-gaging station and the ungaged location to less than about 100 miles.

7. The drainage-area ratio method reported here is designed for estimation of daily mean streamflow for individual ungaged locations. For the method it is inappropriate to subdivide a watershed into two or more subwatersheds, apply the method to each subwatershed, and compute the sum of the estimates. It is inappropriate because the $\phi$ are not equal to 1. For example, suppose watershed $\mathrm{A}$ has a drainage area of 100 square miles and a discharge of 300 cubic feet per second. A nearby ungaged watershed $\mathrm{B}$ also has a drainage area of 100 square miles. Using a general value of $\phi=0.90$, the estimate of the discharge for watershed $B=(300)(100 / 100)^{0.90}=300$ cubic feet per second. If watershed $\mathrm{B}$ instead is subdivided into two subwatersheds $\left(\mathrm{B}_{1}\right.$ and $\left.\mathrm{B}_{2}\right)$ with drainage areas of 25 and 75 square miles, respectively, the estimated discharges are 86 cubic feet per second and 232 cubic feet per second. The sum of the discharges does not equal 300 cubic feet per second. The inappropriateness of subdivision is thus demonstrated.

\section{Example Application of Drainage-Area Ratio Method}

A diagrammatic representation (fig. 7) of drainage-area ratio method for Texas is illustrated to clarify several concepts presented herein. A hypothetical ungaged watershed (U) requires an estimate of streamflow in cubic feet per second for October 4 . The 40-square mile watershed is undeveloped. Five candidate streamflow-gaging stations are available. Watershed 3 is not used because it is more than 100 miles away and other applicable watersheds ( 1 and 2 ) are nearby. Watershed 4 is not used because the analyst considers the basin highly regulated and dissimilar to the ungaged watershed. Watershed 5 is not used because the analyst considers the basin too urbanized and dissimilar to the ungaged watershed. Hence, watersheds 1 and 2 can be used to estimate the streamflow for the ungaged watershed. Each watershed provides a separate estimate of streamflow for the ungaged watershed. As anticipated for a given day, watersheds 1 and 2 are exhibiting streamflow at different 
percentiles. Therefore, the suggested $\phi$ value (table 5) differs for each watershed. The computations are shown in the lower right corner of the diagram. The arithmetic mean of the two estimates is used for the final estimate of about 57 cubic feet per second. Appendix 1 provides a summary of the drainage-area ratio method that includes some illustrative examples of estimating streamflow for selected USGS stations and TCEQ sites.

\section{Summary}

Analysts and managers of surface-water resources often require streamflow data for stream locations where no data were collected or for streamflow-gaging stations for periods during which the gage was not in operation. For example, if waterquality data are collected for the regulatory stream location and a concurrent streamflow measurement is not made, then the streamflow of the location requires estimation. This estimation often is made by using the drainage-area ratio method and is based on concurrent-in-time (same day) streamflow for one or more nearby and operating streamflow-gaging stations. Examination of the drainage-area ratio method for daily streamflow estimation is needed.

The drainage-area ratio method commonly is used to estimate streamflow for sites where no streamflow data are available by using data from a nearby streamflow-gaging station. The method is intuitive and straightforward to implement, and the method is in widespread use by analysts and managers of surface-water resources. The method equates the ratio of streamflow at two stream locations to the ratio of the respective drainage areas. In practice, unity often is assumed as the exponent on the drainage-area ratio, and unity is assumed as a multiplicative bias correction. These two assumptions are evaluated in this investigation through statewide analysis of daily mean streamflow in Texas. The investigation was made by the U.S. Geological Survey in cooperation with the Texas Commission on Environmental Quality.

The analysis of the drainage-area ratio method reported here is based on the period of record of daily mean streamflow and the (contributing) drainage areas for 712 USGS streamflow-gaging stations. The total number of daily values available is in excess of 7.8 million. For the analysis reported here, no further subselection of stations according to streamflow regulation or general land use (developed or undeveloped) was made.

Also, the entire period of record for each station was used. Graphical review or statistical tests for temporal trends with the purpose of rejecting (or accepting) specific stations or specific portions of the data record for some stations were not made.

To account for the influence of streamflow probability on the drainage-area ratio method, 34 percentile ranges of daily mean streamflow were considered. The 34 ranges are the 4 quartiles (0-25, 25-50, 50-75, and 75-100 percent), the 5 intervals of the lower tail of the streamflow distribution (0-1, $1-2,2-3,3-4$, and $4-5$ percent), the 20 quintiles of the 4 quartiles $(0-5,5-10,10-15,15-20,20-25,25-30,30-35,35-40$,
$40-45,45-50,50-55,55-60,60-65,65-70,70-75,75-80$, 80-85, 85-90, 90-95, and 95-100 percent), and the 5 intervals of the upper tail of the streamflow distribution (95-96, 96-97, 97-98, 98-99 and 99-100 percent). For each of the 253,116 $(712 \times 711 / 2)$ unique pairings of stations and for each of the 34 percentile ranges, the concurrent daily mean streamflow values available for the two stations provided for station-pair specific statistical summarization (median, mean, and standard deviation) of both the exponent and bias-correction components of the drainage-area ratio method. Statewide statistics (median, mean, and standard deviation) of the station-pair specific statistics subsequently were computed and are tabulated.

A separate analysis considered conditioning station pairs to those stations within 100 miles of each other and with the absolute value of the logarithm (base-10) of the ratio of the drainage areas greater than or equal to 0.25 . Statewide statistics of the conditional station-pair specific statistics were computed and are tabulated. The conditional analysis is preferable primarily because of the anticipation that small separation distances reflect similar hydrologic conditions and the large variation in exponent estimates for similar drainage areas.

The conditional analysis strongly indicates that same-day and same-percentile streamflow does not scale by per-unit drainage area basis $(\phi=1)$, but instead scales on a fractional power of drainage area $(\phi<1)$. Further, $\phi$ is a function of streamflow percentile (probability). The analysis also indicates that quartiles of streamflow are too wide for reliable estimation of both values for $\phi$ or $K$.

The analysis demonstrates that the exponent is about 0.89 for streamflow percentiles from 0 to about 50 percent, is about 0.92 for percentiles from about 50 to about 65 percent, and is about 0.93 for percentiles from about 65 to about 85 percent. The exponent decreases rapidly to about 0.70 for percentiles nearing 100 percent. The bias-correction factor is about 1.00-1.01 for most percentiles ranges, but it is considerably larger as the interval of analysis (for example, the 75-100 percentile range of streamflow) becomes large. Finally, for general application, suggested values of the exponent are tabulated for 54 percentiles of daily mean streamflow in Texas; when these values are used, the bias correction is unity.

\section{References}

Asquith, W.H., and Slade, R.M., 1997, Regional equations for estimation of peak-streamflow frequency for natural basins in Texas: U.S. Geological Survey Water-Resources Investigations Report 96-4307, 68 p.

Asquith, W.H., and Thompson, D.B., 2005, Alternative regression equations for estimation of annual peak-streamflow frequency for undeveloped watersheds in Texas using PRESS minimization: Texas Tech University, Center for Multidisciplinary Research in Transportation, Texas Department of Transportation Research Report 0-4405-2, 27 p. 
Asquith, W.H., Vrabel, Joseph, and Roussel, M.C., 2007a, Summary of percentages of zero daily mean streamflow for 712 U.S. Geological Survey streamflow-gaging stations in Texas through 2003: U.S. Geological Survey Data Series 247, 721 p. Available online.

Asquith, W.H., Vrabel, Joseph, and Roussel, M.C., 2007b, Summary of annual mean, maximum, minimum, and L-scale statistics of daily mean streamflow for 712 U.S. Geological Survey streamflow-gaging stations in Texas through 2003: U.S. Geological Survey Data Series 248, 721 p. Available online.

Berenbrock, C., 2002, Estimating the magnitude of peak flows at selected recurrence intervals for streams in Idaho: U.S. Geological Survey Water-Resources Investigations Report 02-4170, $59 \mathrm{p}$.

California Environmental Protection Agency, State Water Resources Control Board, Water Rights, 2005, Example format for WAA/CFII report: accessed on November 2, 2005 at http://www.waterrights.ca.gov/forms/ waa_cfii_report_format_example_aug042004pdf

Dingman, S.L., 2002, Physical hydrology: New Jersey, Prentice Hall, $646 \mathrm{p}$.

Duan, N., 1983, Smearing estimate-A nonparametric retransformation method: Journal of the American Statistical Association, v. 78, p. 605-610.

Emerson, D.G., Vecchia, A.V., and Dahl, A.L., 2005, Evaluation of drainage-area ratio method used to estimate streamflow for the Red River of the North basin, North Dakota and Minnesota: U.S. Geological Survey Scientific Investigations Report 2005-5017, 13 p.

Helsel, D.R., and Hirsch, R.M., 1992, Statistical methods in water resources-Studies in environmental science 49: New York, Elsevier, 522 p.

Hirsch, R.M., 1979, An evaluation of some record reconstruction techniques: Water Resources Research, v. 18, no. 4, p. 1,081-1,088.

Hortness, J., 2006, Estimating low-flow frequency statistics for unregulated streams in Idaho: U.S. Geological Survey Scientific Investigations Report 2006-5035, 31 p.

Kjelstrom, L.C., 1998, Methods for estimating selected flowduration and flood-frequency characteristics at ungaged sites in central Idaho: U.S. Geological Survey Water-Resources Investigations Report 94-4120, $10 \mathrm{p}$.

Michigan Department of Environmental Quality, 2005, Drought flow fact sheet: accessed on October 28, 2005 at http://www.deq.state.mi.us/documents/ deq-lwm-hydro-drought_flow_fact_sheet.pdf

Oregon State University, 2005, Streamflow evaluations for watershed restoration planning and design: accessed on November 2, 2005 at http://water.oregonstate.edu/ streamflow/manipulation

Parrett, C., and Johnson, D.R., 2004, Methods for estimating flood frequency in Montana based on data through water year 1998: U.S. Geological Survey Water-Resources Investigations Report 03-4308, 101 p., 1 pl.

Perry, C.A., Wolock, D.M., and Artman, J.C., 2002, Estimates of median flows for streams on the Kansas surface water register: U.S. Geological Survey Water-Resources Investigations Report 02-4292, 107 p.

Ries, K.G., and Friez, P.J., 2000, Methods for estimating lowflow statistics for Massachusetts streams: U.S. Geological Survey Water-Resources Investigations Report 00-4135, $81 \mathrm{p}$.

Stamey, T.C., and Hess, G.W., 1993, Techniques for estimating magnitude and frequency of floods in rural basins of Georgia: U.S. Geological Survey Water-Resources Investigations Report 93-4016, 75 p.

U.S. Geological Survey, 2005, National Water Information System: accessed on various days in July 2005 at http://nwis.waterdata.usgs.gov/nwis/discharge

Vogel, R.M., and Fennessey, N.M., 1994, Flow-duration curves, I-New interpretation and confidence intervals: Journal of Water Resources Planning and Management, v. 120 , p. $485-504$.

Vogel, R.M., and Fennessey, N.M., 1995, Flow-duration curves, II-A review of applications in water resources planning: Water Resources Bulletin, v. 31, p. 1,029-1,039.

Wurbs, R.A., 2005, Water Rights Analysis Package (WRAP) modeling system reference manual: College Station, Texas, Texas Water Resources Institute Technical Report No. 255, $229 \mathrm{p}$. 


\section{Statewide Analysis of the Drainage-Area Ratio Method for 34 Streamflow Percentile Ranges in Texas}

Table 1. U.S. Geological Survey streamflow-gaging stations in Texas with at least 1 year of daily mean streamflow data.

[USGS, U.S. Geological Survey; no., number; $\mathrm{mi}^{2}$, square miles]

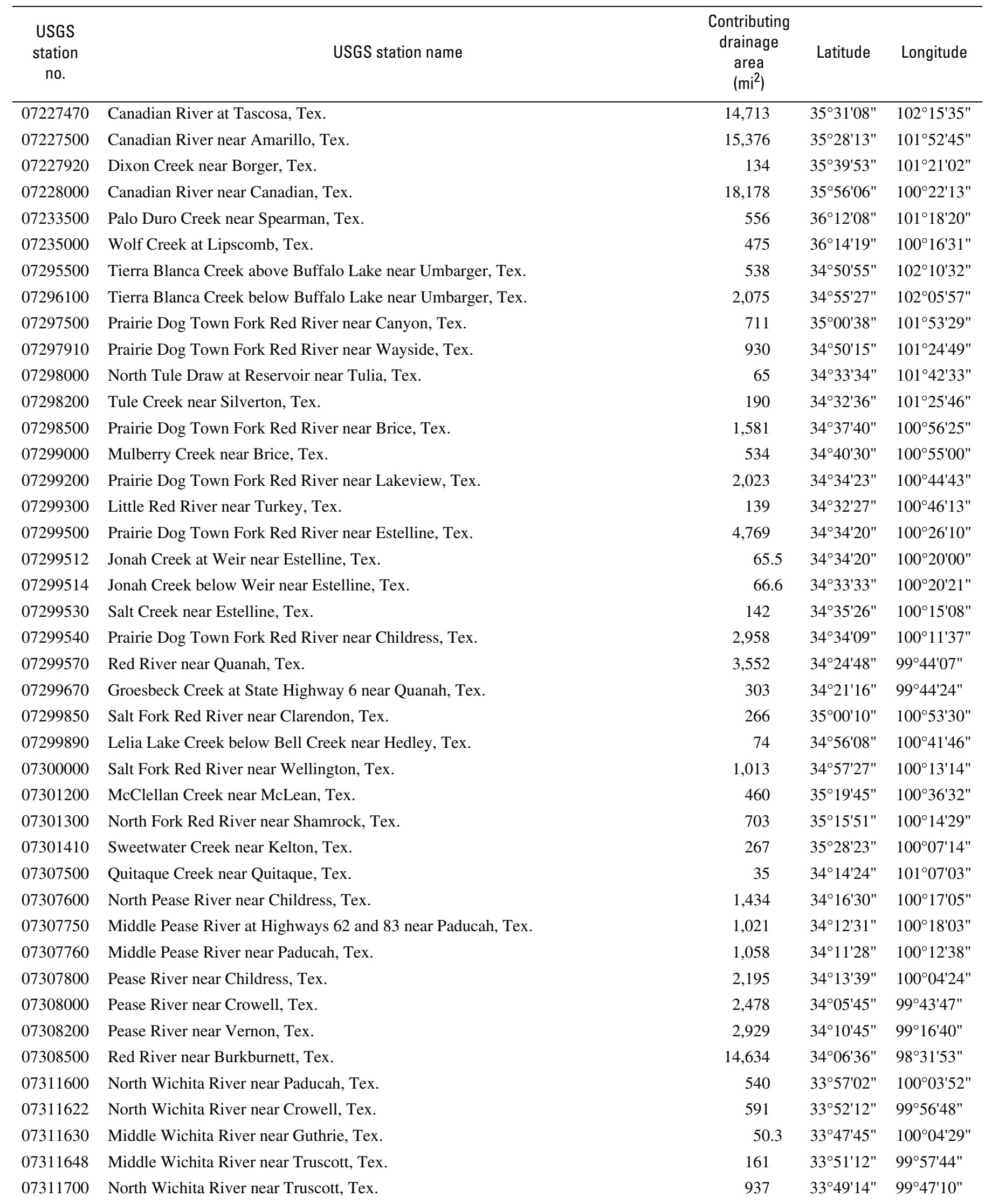


Table 1. U.S. Geological Survey streamflow-gaging stations in Texas with at least 1 year of daily mean streamflow data—Continued.

\begin{tabular}{|c|c|c|c|c|}
\hline $\begin{array}{l}\text { USGS } \\
\text { station } \\
\text { no. }\end{array}$ & USGS station name & $\begin{array}{c}\text { Contributing } \\
\text { drainage } \\
\text { area } \\
\left(\mathrm{mi}^{2}\right)\end{array}$ & Latitude & Longitude \\
\hline 07311780 & South Wichita River near Guthrie, Tex. & 219 & $33^{\circ} 37^{\prime} 29^{\prime \prime}$ & $100^{\circ} 13^{\prime} 04^{\prime \prime}$ \\
\hline 07311782 & South Wichita River at Low Flow Dam near Guthrie, Tex. & 223 & $33^{\circ} 37^{\prime} 19^{\prime \prime}$ & $100^{\circ} 12^{\prime} 31^{\prime \prime}$ \\
\hline 07311783 & South Wichita River below Low Flow Dam near Guthrie, Tex. & 223 & $33^{\circ} 37^{\prime} 19^{\prime \prime}$ & $100^{\circ} 12^{\prime} 31^{\prime \prime}$ \\
\hline 07311800 & South Wichita River near Benjamin, Tex. & 584 & $33^{\circ} 38^{\prime} 39^{\prime \prime}$ & $99^{\circ} 48^{\prime} 02^{\prime \prime}$ \\
\hline 07311900 & Wichita River near Seymour, Tex. & 1,874 & $33^{\circ} 42^{\prime} 01^{\prime \prime}$ & $99^{\circ} 23^{\prime} 18^{\prime \prime}$ \\
\hline 07312100 & Wichita River near Mabelle, Tex. & 2,086 & $33^{\circ} 45^{\prime} 36^{\prime \prime}$ & $99^{\circ} 08^{\prime} 33^{\prime \prime}$ \\
\hline 07312130 & Wichita River at State Highway 25 near Kamay, Tex. & 2,246 & $33^{\circ} 52^{\prime} 09^{\prime \prime}$ & $98^{\circ} 50^{\prime} 20^{\prime \prime}$ \\
\hline 07314500 & Little Wichita River near Archer City, Tex. & 481 & $33^{\circ} 39^{\prime} 45^{\prime \prime}$ & $98^{\circ} 36^{\prime} 46^{\prime \prime}$ \\
\hline 07314900 & Little Wichita River above Henrietta, Tex. & 1,037 & $33^{\circ} 49^{\prime} 36^{\prime \prime}$ & $98^{\circ} 14^{\prime} 23^{\prime \prime}$ \\
\hline 07315200 & East Fork Little Wichita River near Henrietta, Tex. & 178 & $33^{\circ} 48^{\prime} 46^{\prime \prime}$ & $98^{\circ} 05^{\prime} 05^{\prime \prime}$ \\
\hline 07315400 & Little Wichita River near Ringgold, Tex. & 1,350 & $33^{\circ} 53^{\prime} 55^{\prime \prime}$ & $98^{\circ} 04^{\prime} 05^{\prime \prime}$ \\
\hline 07316200 & Mineral Creek near Sadler, Tex. & 26 & $33^{\circ} 42^{\prime} 08^{\prime \prime}$ & $96^{\circ} 50^{\prime} 51^{\prime \prime}$ \\
\hline 07332600 & Bois D' Arc Creek near Randolph, Tex. & 72 & $33^{\circ} 28^{\prime} 32^{\prime \prime}$ & $96^{\circ} 12^{\prime} 52^{\prime \prime}$ \\
\hline 07335400 & Sanders Creek near Chicota, Tex. & 175 & $33^{\circ} 51^{\prime} 09^{\prime \prime}$ & $95^{\circ} 32^{\prime} 40^{\prime \prime}$ \\
\hline 07336750 & Little Pine Creek near Kanawha, Tex. & 75.4 & $33^{\circ} 50^{\prime} 26^{\prime \prime}$ & $95^{\circ} 15^{\prime} 55^{\prime \prime}$ \\
\hline 07336800 & Pecan Bayou near Clarksville, Tex. & 100 & $33^{\circ} 41^{\prime} 07^{\prime \prime}$ & $94^{\circ} 59^{\prime} 41^{\prime \prime}$ \\
\hline 07343200 & Sulphur River near Talco, Tex. & 1,405 & $33^{\circ} 23^{\prime} 26^{\prime \prime}$ & $95^{\circ} 03^{\prime} 44^{\prime \prime}$ \\
\hline 07343300 & Cuthand Creek near Bogata, Tex. & 69 & $33^{\circ} 32^{\prime} 51^{\prime \prime}$ & $95^{\circ} 10^{\prime} 22^{\prime \prime}$ \\
\hline 07343500 & White Oak Creek near Talco, Tex. & 494 & $33^{\circ} 19^{\prime} 20^{\prime \prime}$ & $95^{\circ} 05^{\prime} 33^{\prime \prime}$ \\
\hline 07344000 & Sulphur River near Darden, Tex. & 2,774 & $33^{\circ} 15^{\prime} 00^{\prime \prime}$ & $94^{\circ} 37^{\prime} 00^{\prime \prime}$ \\
\hline 07344482 & Big Cypress Creek near Winnsboro, Tex. & 27.2 & $33^{\circ} 01 ' 24 "$ & $95^{\circ} 16^{\prime} 12^{\prime \prime}$ \\
\hline 07344486 & Brushy Creek at Scroggins, Tex. & 23.4 & $32^{\circ} 58^{\prime} 32^{\prime \prime}$ & $95^{\circ} 11^{\prime} 03^{\prime \prime}$ \\
\hline 07344500 & Big Cypress Creek near Pittsburg, Tex. & 370 & $33^{\circ} 01^{\prime} 15^{\prime \prime}$ & $94^{\circ} 52^{\prime} 55^{\prime \prime}$ \\
\hline 07345000 & Boggy Creek near Daingerfield, Tex. & 72 & $33^{\circ} 02^{\prime} 10^{\prime \prime}$ & $94^{\circ} 47^{\prime} 15^{\prime \prime}$ \\
\hline 07346000 & Big Cypress Creek near Jefferson, Tex. & 850 & $32^{\circ} 44^{\prime} 58^{\prime \prime}$ & $94^{\circ} 29^{\prime} 55^{\prime \prime}$ \\
\hline 07346045 & Black Cypress Bayou at Jefferson, Tex. & 365 & $32^{\circ} 46^{\prime} 40^{\prime \prime}$ & $94^{\circ} 21^{\prime} 26^{\prime \prime}$ \\
\hline 07346050 & Little Cypress Creek near Ore City, Tex. & 383 & $32^{\circ} 40^{\prime} 21^{\prime \prime}$ & $94^{\circ} 45^{\prime} 03^{\prime \prime}$ \\
\hline 07346070 & Little Cypress Creek near Jefferson, Tex. & 675 & $32^{\circ} 42^{\prime} 46^{\prime \prime}$ & $94^{\circ} 20^{\prime} 45^{\prime \prime}$ \\
\hline 07346140 & Frazier Creek near Linden, Tex. & 48 & $33^{\circ} 03^{\prime} 14^{\prime \prime}$ & $94^{\circ} 17^{\prime} 24^{\prime \prime}$ \\
\hline 08017200 & Cowleech Fork Sabine River at Greenville, Tex. & 77.7 & $33^{\circ} 07^{\prime} 58^{\prime \prime}$ & $96^{\circ} 04^{\prime} 36^{\prime \prime}$ \\
\hline 08017300 & South Fork Sabine River near Quinlan, Tex. & 78.7 & $32^{\circ} 53^{\prime} 52^{\prime \prime}$ & $96^{\circ} 15^{\prime} 11^{\prime \prime}$ \\
\hline 08017410 & Sabine River near Wills Point, Tex. & 756 & $32^{\circ} 48^{\prime} 22^{\prime \prime}$ & $95^{\circ} 55^{\prime} 09^{\prime \prime}$ \\
\hline 08017500 & Sabine River near Emory, Tex. & 888 & $32^{\circ} 46 \prime 23 "$ & $95^{\circ} 47^{\prime} 56^{\prime \prime}$ \\
\hline
\end{tabular}


Table 1. U.S. Geological Survey streamflow-gaging stations in Texas with at least 1 year of daily mean streamflow data—Continued.

\begin{tabular}{|c|c|c|c|c|}
\hline $\begin{array}{c}\text { USGS } \\
\text { station } \\
\text { no. }\end{array}$ & USGS station name & $\begin{array}{c}\text { Contributing } \\
\text { drainage } \\
\text { area } \\
\left(\mathrm{mi}^{2}\right)\end{array}$ & Latitude & Longitude \\
\hline 08018500 & Sabine River near Mineola, Tex. & 1,357 & $32^{\circ} 36^{\prime} 49^{\prime \prime}$ & $95^{\circ} 29^{\prime} 08^{\prime \prime}$ \\
\hline 08018730 & Burke Creek near Yantis, Tex. & 33.1 & $32^{\circ} 59^{\prime} 26^{\prime \prime}$ & $95^{\circ} 37^{\prime} 18^{\prime \prime}$ \\
\hline 08019000 & Lake Fork Creek near Quitman, Tex. & 585 & $32^{\circ} 45^{\prime} 47^{\prime \prime}$ & $95^{\circ} 27^{\prime} 46^{\prime \prime}$ \\
\hline 08019200 & Sabine River near Hawkins, Tex. & 2,259 & $32^{\circ} 33^{\prime} 35^{\prime \prime}$ & $95^{\circ} 12^{\prime} 23^{\prime \prime}$ \\
\hline 08019500 & Big Sandy Creek near Big Sandy, Tex. & 231 & $32^{\circ} 36^{\prime} 14^{\prime \prime}$ & $95^{\circ} 05^{\prime} 29^{\prime \prime}$ \\
\hline 08020000 & Sabine River near Gladewater, Tex. & 2,791 & $32^{\circ} 31^{\prime} 37^{\prime \prime}$ & $94^{\circ} 57^{\prime} 36^{\prime \prime}$ \\
\hline 08020200 & Prairie Creek near Gladewater, Tex. & 48.9 & $32^{\circ} 28^{\prime} 45^{\prime \prime}$ & $94^{\circ} 57^{\prime} 14^{\prime \prime}$ \\
\hline 08020450 & Sabine River above Longview, Tex. & 2,943 & $32^{\circ} 28^{\prime} 47^{\prime \prime}$ & $94^{\circ} 48^{\prime} 15^{\prime \prime}$ \\
\hline 08020500 & Sabine River near Longview, Tex. & 2,947 & $32^{\circ} 28^{\prime} 00^{\prime \prime}$ & $94^{\circ} 46^{\prime} 50^{\prime \prime}$ \\
\hline 08020700 & Rabbit Creek at Kilgore, Tex. & 75.8 & $32^{\circ} 23^{\prime} 17^{\prime \prime}$ & $94^{\circ} 54^{\prime} 11^{\prime \prime}$ \\
\hline 08020900 & Sabine River below Longview, Tex. & 3,155 & $32^{\circ} 25^{\prime} 00^{\prime \prime}$ & $94^{\circ} 42^{\prime} 35^{\prime \prime}$ \\
\hline 08020960 & Mill Creek near Henderson, Tex. & 20.3 & $32^{\circ} 14^{\prime} 02^{\prime \prime}$ & $94^{\circ} 464^{\prime \prime}$ \\
\hline 08020980 & Mill Creek near Longview, Tex. & 47.9 & $32^{\circ} 18^{\prime} 18^{\prime \prime}$ & $94^{\circ} 43^{\prime} 41^{\prime \prime}$ \\
\hline 08020990 & Tiawichi Creek near Longview, Tex. & 62.7 & $32^{\circ} 19^{\prime} 14^{\prime \prime}$ & $94^{\circ} 43^{\prime} 57^{\prime \prime}$ \\
\hline 08021000 & Cherokee Bayou near Elderville, Tex. & 120 & $32^{\circ} 20^{\prime} 00^{\prime \prime}$ & $94^{\circ} 42^{\prime} 00^{\prime \prime}$ \\
\hline 08022040 & Sabine River near Beckville, Tex. & 3,589 & $32^{\circ} 19^{\prime} 38^{\prime \prime}$ & $94^{\circ} 21^{\prime} 12^{\prime \prime}$ \\
\hline 08022070 & Martin Creek near Tatum, Tex. & 148 & $32^{\circ} 17^{\prime} 44^{\prime \prime}$ & $94^{\circ} 29^{\prime} 29^{\prime \prime}$ \\
\hline 08022300 & Murvaul Bayou near Gary, Tex. & 134 & $32^{\circ} 02^{\prime} 54^{\prime \prime}$ & $94^{\circ} 22^{\prime} 31^{\prime \prime}$ \\
\hline 08022400 & Socagee Creek near Carthage, Tex. & 82.6 & $32^{\circ} 13^{\prime} 54^{\prime \prime}$ & $94^{\circ} 05^{\prime} 31^{\prime \prime}$ \\
\hline 08022500 & Sabine River at Logansport, La. & 4,839 & $31^{\circ} 58 ' 20^{\prime \prime}$ & $94^{\circ} 00^{\prime} 22^{\prime \prime}$ \\
\hline 08023200 & Tenaha Creek near Shelbyville, Tex. & 97.8 & $31^{\circ} 45^{\prime} 56^{\prime \prime}$ & $94^{\circ} 05^{\prime} 02^{\prime \prime}$ \\
\hline 08024400 & Sabine River near Milam, Tex. & 6,508 & $31^{\circ} 28^{\prime} 01^{\prime \prime}$ & $93^{\circ} 44^{\prime} 41^{\prime \prime}$ \\
\hline 08024500 & Palo Gaucho Bayou near Hemphill, Tex. & 123 & $31^{\circ} 23^{\prime} 10^{\prime \prime}$ & $93^{\circ} 50^{\prime} 08^{\prime \prime}$ \\
\hline 08025307 & Mill Creek near Burkeville, Tex. & 18 & $31^{\circ} 09^{\prime} 23^{\prime \prime}$ & $93^{\circ} 40^{\prime} 35^{\prime \prime}$ \\
\hline 08025360 & Sabine River at Toledo Bend Reservoir near Burkeville, Tex. & 7,178 & $31^{\circ} 10^{\prime} 25^{\prime \prime}$ & $93^{\circ} 33^{\prime} 57^{\prime \prime}$ \\
\hline 08026000 & Sabine River near Burkeville, Tex. & 7,482 & $31^{\circ} 03^{\prime} 50^{\prime \prime}$ & $93^{\circ} 31^{\prime} 10^{\prime \prime}$ \\
\hline 08028500 & Sabine River near Bon Wier, Tex. & 8,229 & $30^{\circ} 44^{\prime} 49^{\prime \prime}$ & $93^{\circ} 36^{\prime} 30^{\prime \prime}$ \\
\hline 08029500 & Big Cow Creek near Newton, Tex. & 128 & $30^{\circ} 49^{\prime} 08^{\prime \prime}$ & $93^{\circ} 47^{\prime} 08^{\prime \prime}$ \\
\hline 08030000 & Cypress Creek near Buna, Tex. & 69.2 & $30^{\circ} 25^{\prime} 52^{\prime \prime}$ & $93^{\circ} 54^{\prime} 28^{\prime \prime}$ \\
\hline 08030500 & Sabine River near Ruliff, Tex. & 9,329 & $30^{\circ} 18^{\prime} 13^{\prime \prime}$ & $93^{\circ} 44^{\prime} 37^{\prime \prime}$ \\
\hline 08031000 & Cow Bayou near Mauriceville, Tex. & 83.3 & $30^{\circ} 11^{\prime} 10^{\prime \prime}$ & $93^{\circ} 54^{\prime} 30^{\prime \prime}$ \\
\hline 08031200 & Kickapoo Creek near Brownsboro, Tex. & 232 & $32^{\circ} 18^{\prime} 34^{\prime \prime}$ & $95^{\circ} 36^{\prime} 19^{\prime \prime}$ \\
\hline 08031500 & Neches River near Reese, Tex. & 851 & $32^{\circ} 01 ' 30^{\prime \prime}$ & $95^{\circ} 25^{\prime} 40^{\prime \prime}$ \\
\hline 08032000 & Neches River near Neches, Tex. & 1,145 & $31^{\circ} 53^{\prime} 32^{\prime \prime}$ & $95^{\circ} 25^{\prime} 50^{\prime \prime}$ \\
\hline 08032500 & Neches River near Alto, Tex. & 1,945 & $31^{\circ} 34^{\prime} 45^{\prime \prime}$ & $95^{\circ} 09^{\prime} 55^{\prime \prime}$ \\
\hline 08033000 & Neches River near Diboll, Tex. & 2,724 & $31^{\circ} 07 ' 58^{\prime \prime}$ & $94^{\circ} 48^{\prime} 35^{\prime \prime}$ \\
\hline 08033300 & Piney Creek near Groveton, Tex. & 79 & $31^{\circ} 08^{\prime} 25^{\prime \prime}$ & $95^{\circ} 05^{\prime} 11 "$ \\
\hline 08033500 & Neches River near Rockland, Tex. & 3,636 & $31^{\circ} 01^{\prime} 30^{\prime \prime}$ & $94^{\circ} 23^{\prime} 58^{\prime \prime}$ \\
\hline 08033700 & Striker Creek near Summerfield, Tex. & 146 & $32^{\circ} 00^{\prime} 10^{\prime \prime}$ & $94^{\circ} 59^{\prime} 35^{\prime \prime}$ \\
\hline 08033900 & East Fork Angelina River near Cushing, Tex. & 158 & $31^{\circ} 51^{\prime} 36^{\prime \prime}$ & $94^{\circ} 49^{\prime 2} 23^{\prime \prime}$ \\
\hline 08034500 & Mud Creek near Jacksonville, Tex. & 376 & $31^{\circ} 58^{\prime} 35^{\prime \prime}$ & $95^{\circ} 09^{\prime} 38^{\prime \prime}$ \\
\hline 08035000 & Mud Creek at Ponta, Tex. & 475 & $31^{\circ} 53^{\prime} 21^{\prime \prime}$ & $95^{\circ} 05^{\prime} 19^{\prime \prime}$ \\
\hline 08036500 & Angelina River near Alto, Tex. & 1,276 & $31^{\circ} 40^{\prime} 10^{\prime \prime}$ & $94^{\circ} 57^{\prime 2} 24^{\prime \prime}$ \\
\hline
\end{tabular}


Table 1. U.S. Geological Survey streamflow-gaging stations in Texas with at least 1 year of daily mean streamflow data—Continued.

\begin{tabular}{|c|c|c|c|c|}
\hline $\begin{array}{l}\text { USGS } \\
\text { station } \\
\text { no. }\end{array}$ & USGS station name & $\begin{array}{l}\text { Contributing } \\
\text { drainage } \\
\text { area } \\
\left(\mathrm{mi}^{2}\right)\end{array}$ & Latitude & Longitude \\
\hline 08037000 & Angelina River near Lufkin, Tex. & 1,600 & $31^{\circ} 27^{\prime} 26^{\prime \prime}$ & $94^{\circ} 43^{\prime} 34^{\prime \prime}$ \\
\hline 08037050 & Bayou Lanana at Nacogdoches, Tex. & 31.3 & $31^{\circ} 366^{\prime} 58^{\prime \prime}$ & $94^{\circ} 38^{\prime} 28^{\prime \prime}$ \\
\hline 08037500 & Arenoso Creek near San Augustine, Tex. & 75.3 & $31^{\circ} 35^{\prime} 48^{\prime \prime}$ & $94^{\circ} 16^{\prime} 06^{\prime \prime}$ \\
\hline 08038500 & Angelina River near Zavalla, Tex. & 2,892 & $31^{\circ} 12^{\prime} 41^{\prime \prime}$ & $94^{\circ} 17^{\prime} 40^{\prime \prime}$ \\
\hline 08039100 & Ayish Bayou near San Augustine, Tex. & 89 & $31^{\circ} 23^{\prime} 46^{\prime \prime}$ & $94^{\circ} 09^{\prime} 03^{\prime \prime}$ \\
\hline 08039500 & Angelina River near Ebenezer, Tex. & 3,486 & $31^{\circ} 00^{\prime} 54^{\prime \prime}$ & $94^{\circ} 09^{\prime} 07^{\prime \prime}$ \\
\hline 08040600 & Neches River near Town Bluff, Tex. & 7,574 & $30^{\circ} 47^{\prime} 27^{\prime \prime}$ & $94^{\circ} 09^{\prime} 03^{\prime \prime}$ \\
\hline 08041000 & Neches River at Evadale, Tex. & 7,951 & $30^{\circ} 21^{\prime} 20^{\prime \prime}$ & $94^{\circ} 05^{\prime} 35^{\prime \prime}$ \\
\hline 08042500 & Hillebrandt Bayou near Lovell Lake, Tex. & 128 & $29^{\circ} 55^{\prime} 44^{\prime \prime}$ & $94^{\circ} 06^{\prime} 35^{\prime \prime}$ \\
\hline 08042700 & North Creek near Jacksboro, Tex. & 21.6 & $33^{\circ} 16^{\prime} 57^{\prime \prime}$ & $98^{\circ} 17^{\prime} 53^{\prime \prime}$ \\
\hline 08042800 & West Fork Trinity River near Jacksboro, Tex. & 683 & $33^{\circ} 17^{\prime} 30^{\prime \prime}$ & $98^{\circ} 04^{\prime} 49^{\prime \prime}$ \\
\hline 08042900 & Beans Creek at Wizard Wells, Tex. & 29.6 & $33^{\circ} 11^{\prime} 59^{\prime \prime}$ & $97^{\circ} 58^{\prime} 01^{\prime \prime}$ \\
\hline 08043500 & West Fork Trinity River at Bridgeport, Tex. & 1,147 & $33^{\circ} 12^{\prime} 05^{\prime \prime}$ & $97^{\circ} 45^{\prime} 21^{\prime \prime}$ \\
\hline 08043950 & Big Sandy Creek near Chico, Tex. & 312 & $33^{\circ} 16^{\prime} 27^{\prime \prime}$ & $97^{\circ} 40^{\prime} 42^{\prime \prime}$ \\
\hline 08044000 & Big Sandy Creek near Bridgeport, Tex. & 333 & $33^{\circ} 13^{\prime} 54^{\prime \prime}$ & $97^{\circ} 41^{\prime} 40^{\prime \prime}$ \\
\hline 08044135 & Garrett Creek near Paradise, Tex. & 52.5 & $33^{\circ} 06^{\prime} 18^{\prime \prime}$ & $97^{\circ} 39^{\prime} 17^{\prime \prime}$ \\
\hline 08047000 & Clear Fork Trinity River near Benbrook, Tex. & 431 & $32^{\circ} 39^{\prime} 54^{\prime \prime}$ & $97^{\circ} 26^{\prime} 30^{\prime \prime}$ \\
\hline 08047050 & Marys Creek at Benbrook, Tex. & 54 & $32^{\circ} 41^{\prime} 42^{\prime \prime}$ & $97^{\circ} 26^{\prime} 49^{\prime \prime}$ \\
\hline 08047500 & Clear Fork Trinity River at Fort Worth, Tex. & 518 & $32^{\circ} 43^{\prime} 56^{\prime \prime}$ & $97^{\circ} 21^{\prime} 31^{\prime \prime}$ \\
\hline 08048000 & West Fork Trinity River at Fort Worth, Tex. & 2,615 & $32^{\circ} 45^{\prime} 39^{\prime \prime}$ & $97^{\circ} 19^{\prime} 56^{\prime \prime}$ \\
\hline 08048520 & Sycamore Creek at Interstate Highway 35 West, Fort Worth, Tex. & 17.7 & $32^{\circ} 39^{\prime} 55^{\prime \prime}$ & $97^{\circ} 19^{\prime} 16^{\prime \prime}$ \\
\hline 08048530 & Sycamore Creek Tributary above Semenary South Shopping Center, Fort Worth, Tex. & .97 & $32^{\circ} 41^{\prime} 08^{\prime \prime}$ & $97^{\circ} 19^{\prime} 44^{\prime \prime}$ \\
\hline 08048540 & Sycamore Creek Tributary at Interstate Highway 35 West, Fort Worth, Tex. & 1.35 & $32^{\circ} 41^{\prime} 18^{\prime \prime}$ & $97^{\circ} 19^{\prime} 11^{\prime \prime}$ \\
\hline 08048543 & West Fork Trinity River at Beach Street, Fort Worth, Tex. & 2,685 & $32^{\circ} 45^{\prime} 06^{\prime \prime}$ & $97^{\circ} 17^{\prime} 21^{\prime \prime}$ \\
\hline 08048600 & Dry Branch at Fain Street at Fort Worth, Tex. & 2.15 & $32^{\circ} 46^{\prime} 34^{\prime \prime}$ & $97^{\circ} 17^{\prime} 18^{\prime \prime}$ \\
\hline 08048800 & Big Fossil Creek at Haltom City, Tex. & 52.8 & $32^{\circ} 48^{\prime} 26^{\prime \prime}$ & $97^{\circ} 14^{\prime} 54^{\prime \prime}$ \\
\hline 08048850 & Little Fossil Creek at Mesquite Street, Fort Worth, Tex. & 12.3 & $32^{\circ} 48^{\prime} 33^{\prime \prime}$ & $97^{\circ} 17^{\prime} 28^{\prime \prime}$ \\
\hline 08048970 & Village Creek at Everman, Tex. & 84.5 & $32^{\circ} 36^{\prime} 12^{\prime \prime}$ & $97^{\circ} 15^{\prime} 53^{\prime \prime}$ \\
\hline 08048980 & Village Creek at Kennedale, Tex. & 100 & $32^{\circ} 38^{\prime} 28^{\prime \prime}$ & $97^{\circ} 14^{\prime} 31^{\prime \prime}$ \\
\hline 08049000 & Village Creek near Handley, Tex. & 126 & $32^{\circ} 42^{\prime} 00^{\prime \prime}$ & $97^{\circ} 13^{\prime} 00^{\prime \prime}$ \\
\hline 08049500 & West Fork Trinity River at Grand Prairie, Tex. & 3,065 & $32^{\circ} 47^{\prime} 55^{\prime \prime}$ & $97^{\circ} 01^{\prime} 46^{\prime \prime}$ \\
\hline 08049550 & Big Bear Creek near Grapevine, Tex. & 29.6 & $32^{\circ} 54^{\prime} 48^{\prime \prime}$ & $97^{\circ} 07^{\prime} 44^{\prime \prime}$ \\
\hline 08049553 & Big Bear Creek at Euless/Grapevine Road near Grapevine, Tex. & 38.6 & $32^{\circ} 53^{\prime} 41^{\prime \prime}$ & $97^{\circ} 04^{\prime} 56^{\prime \prime}$ \\
\hline
\end{tabular}


Table 1. U.S. Geological Survey streamflow-gaging stations in Texas with at least 1 year of daily mean streamflow data—Continued.

\begin{tabular}{|c|c|c|c|c|}
\hline $\begin{array}{c}\text { USGS } \\
\text { station } \\
\text { no. }\end{array}$ & USGS station name & $\begin{array}{l}\text { Contributing } \\
\text { drainage } \\
\text { area } \\
\left(\mathrm{mi}^{2}\right)\end{array}$ & Latitude & Longitude \\
\hline 08049556 & Unnamed Tributary Big Bear Creek (Outflow 19) near Euless, Tex. & 1.04 & $32^{\circ} 52^{\prime} 19^{\prime \prime}$ & $97^{\circ} 03^{\prime} 24^{\prime \prime}$ \\
\hline 08049565 & Trigg Branch at DFW Airport near Euless, Tex. & 2.62 & $32^{\circ} 52^{\prime} 02^{\prime \prime}$ & $97^{\circ} 02^{\prime} 20^{\prime \prime}$ \\
\hline 08049569 & Big Bear Creek at State Highway 183 near Euless, Tex. & 76.9 & $32^{\circ} 50^{\prime} 08^{\prime \prime}$ & $97^{\circ} 02^{\prime} 09^{\prime \prime}$ \\
\hline 08049580 & Mountain Creek near Venus, Tex. & 25.5 & $32^{\circ} 29^{\prime} 27^{\prime \prime}$ & $97^{\circ} 07^{\prime} 22^{\prime \prime}$ \\
\hline 08049600 & Mountain Creek near Cedar Hill, Tex. & 119 & $32^{\circ} 35^{\prime} 03^{\prime \prime}$ & $97^{\circ} 01 ' 23 "$ \\
\hline 08049700 & Walnut Creek near Mansfield, Tex. & 62.8 & $32^{\circ} 34^{\prime} 51^{\prime \prime}$ & $97^{\circ} 06^{\prime} 06^{\prime \prime}$ \\
\hline 08050000 & Mountain Creek near Grand Prairie, Tex. & 273 & $32^{\circ} 42^{\prime} 20^{\prime \prime}$ & $96^{\circ} 58^{\prime} 00^{\prime \prime}$ \\
\hline 08050100 & Mountain Creek at Grand Prairie, Tex. & 298 & $32^{\circ} 44^{\prime} 51^{\prime \prime}$ & $96^{\circ} 55^{\prime} 32^{\prime \prime}$ \\
\hline 08050300 & Elm Fork Trinity River near Muenster, Tex. & 46 & $33^{\circ} 36^{\prime} 36^{\prime \prime}$ & $97^{\circ} 22^{\prime} 57^{\prime \prime}$ \\
\hline 08050400 & Elm Fork Trinity River at Gainesville, Tex. & 174 & $33^{\circ} 37^{\prime} 27^{\prime \prime}$ & $97^{\circ} 09^{\prime} 22^{\prime \prime}$ \\
\hline 08050500 & Elm Fork Trinity River near Sanger, Tex. & 381 & $33^{\circ} 23^{\prime} 11^{\prime \prime}$ & $97^{\circ} 05^{\prime} 05^{\prime \prime}$ \\
\hline 08050800 & Timber Creek near Collinsville, Tex. & 38.8 & $33^{\circ} 33^{\prime} 16^{\prime \prime}$ & $96^{\circ} 56^{\prime} 49^{\prime \prime}$ \\
\hline 08050840 & Range Creek near Collinsville, Tex. & 29.2 & 333'ㄱ'" & $96^{\circ} 48^{\prime} 25^{\prime \prime}$ \\
\hline 08051000 & Isle Du Bois Creek near Pilot Point, Tex. & 266 & $33^{\circ} 24^{\prime} 23^{\prime \prime}$ & $97^{\circ} 00^{\prime} 45^{\prime \prime}$ \\
\hline 08051130 & Elm Fork Trinity River near Pilot Point, Tex. & 692 & $33^{\circ} 21^{\prime} 01^{\prime \prime}$ & $97^{\circ} 02^{\prime} 49^{\prime \prime}$ \\
\hline 08051500 & Clear Creek near Sanger, Tex. & 295 & $33^{\circ} 20^{\prime} 10^{\prime \prime}$ & $97^{\circ} 10^{\prime} 45^{\prime \prime}$ \\
\hline 08052000 & Elm Fork Trinity River near Denton, Tex. & 1,084 & $33^{\circ} 15^{\prime} 02^{\prime \prime}$ & $97^{\circ} 02^{\prime} 42^{\prime \prime}$ \\
\hline 08052650 & Little Elm Creek near Celina, Tex. & 46.7 & $33^{\circ} 21^{\prime} 55^{\prime \prime}$ & $96^{\circ} 49^{\prime} 25^{\prime \prime}$ \\
\hline 08052700 & Little Elm Creek near Aubrey, Tex. & 75.5 & $33^{\circ} 17^{\prime} 00^{\prime \prime}$ & $96^{\circ} 53^{\prime} 33^{\prime \prime}$ \\
\hline 08052780 & Hickory Creek at Denton, Tex. & 129 & $33^{\circ} 09^{\prime} 06^{\prime \prime}$ & $97^{\circ} 08^{\prime} 30^{\prime \prime}$ \\
\hline 08053000 & Elm Fork Trinity River near Lewisville, Tex. & 1,673 & $33^{\circ} 02^{\prime} 44^{\prime \prime}$ & $96^{\circ} 57^{\prime} 39^{\prime \prime}$ \\
\hline 08053500 & Denton Creek near Justin, Tex. & 400 & $33^{\circ} 07^{\prime} 08^{\prime \prime}$ & $97^{\circ} 17^{\prime} 25^{\prime \prime}$ \\
\hline 08054000 & Denton Creek near Roanoke, Tex. & 621 & $33^{\circ} 02^{\prime} 24^{\prime \prime}$ & $97^{\circ} 12^{\prime} 17^{\prime \prime}$ \\
\hline 08055000 & Denton Creek near Grapevine, Tex. & 705 & $32^{\circ} 59^{\prime} 13^{\prime \prime}$ & $97^{\circ} 00^{\prime} 45^{\prime \prime}$ \\
\hline 08055500 & Elm Fork Trinity River near Carrollton, Tex. & 2,459 & $32^{\circ} 57^{\prime} 57^{\prime \prime}$ & $96^{\circ} 56^{\prime} 39^{\prime \prime}$ \\
\hline 08055700 & Bachman Branch at Dallas, Tex. & 10 & $32^{\circ} 51^{\prime} 37 "$ & $96^{\circ} 51^{\prime} 13^{\prime \prime}$ \\
\hline 08056500 & Turtle Creek at Dallas, Tex. & 7.98 & $32^{\circ} 48^{\prime} 26^{\prime \prime}$ & $96^{\circ} 48^{\prime} 08^{\prime \prime}$ \\
\hline 08057000 & Trinity River at Dallas, Tex. & 6,106 & $32^{\circ} 46^{\prime} 29^{\prime \prime}$ & $96^{\circ} 49^{\prime} 18^{\prime \prime}$ \\
\hline 08057100 & White Rock Creek at Keller Springs Road, Dallas, Tex. & 29.4 & $32^{\circ} 58^{\prime} 13^{\prime \prime}$ & $96^{\circ} 48^{\prime} 19^{\prime \prime}$ \\
\hline 08057200 & White Rock Creek at Greenville Avenue, Dallas, Tex. & 66.4 & $32^{\circ} 53^{\prime} 21^{\prime \prime}$ & $96^{\circ} 45^{\prime} 23^{\prime \prime}$ \\
\hline 08057300 & White Rock Creek at White Rock Lake, Dallas, Tex. & 100 & $32^{\circ} 48^{\prime} 31^{\prime \prime}$ & $96^{\circ} 43^{\prime} 32^{\prime \prime}$ \\
\hline 08057410 & Trinity River below Dallas, Tex. & 6,278 & $32^{\circ} 42^{\prime} 27^{\prime \prime}$ & $96^{\circ} 44^{\prime} 08^{\prime \prime}$ \\
\hline 08057445 & Prairie Creek at U.S. Highway 175, Dallas, Tex. & 9.03 & $32^{\circ} 42^{\prime} 17^{\prime \prime}$ & $96^{\circ} 40^{\prime} 11^{\prime \prime}$ \\
\hline 08057448 & Trinity River near Wilmer, Tex. & 6,387 & $32^{\circ} 37^{\prime} 03^{\prime \prime}$ & $96^{\circ} 37^{\prime} 19^{\prime \prime}$ \\
\hline 08057450 & Tenmile Creek at State Highway 342 at Lancaster, Tex. & 52.8 & $32^{\circ} 34^{\prime} 42^{\prime \prime}$ & $96^{\circ} 45^{\prime} 21^{\prime \prime}$ \\
\hline 08058500 & Honey Creek near McKinney, Tex. & 39 & $33^{\circ} 16^{\prime} 42^{\prime \prime}$ & $96^{\circ} 39^{\prime} 27^{\prime \prime}$ \\
\hline 08058900 & East Fork Trinity River at McKinney, Tex. & 164 & $33^{\circ} 14^{\prime} 38^{\prime \prime}$ & $96^{\circ} 36^{\prime} 31^{\prime \prime}$ \\
\hline 08059000 & East Fork Trinity River near McKinney, Tex. & 190 & $33^{\circ} 12^{\prime} 13^{\prime \prime}$ & $96^{\circ} 35^{\prime} 44^{\prime \prime}$ \\
\hline 08059400 & Sister Grove Creek near Blue Ridge, Tex. & 83.1 & $33^{\circ} 17^{\prime} 40^{\prime \prime}$ & $96^{\circ} 28^{\prime} 58^{\prime \prime}$ \\
\hline 08059500 & Sister Grove Creek near Princeton, Tex. & 113 & $33^{\circ} 11^{\prime} 35^{\prime \prime}$ & $96^{\circ} 28^{\prime} 32^{\prime \prime}$ \\
\hline 08060000 & East Fork Trinity River above Pilot Grove near Lavon, Tex. & 324 & $33^{\circ} 01^{\prime 2} 23^{\prime \prime}$ & $96^{\circ} 28^{\prime} 32^{\prime \prime}$ \\
\hline 08061000 & East Fork Trinity River near Lavon, Tex. & 773 & $33^{\circ} 01^{\prime} 25^{\prime \prime}$ & $96^{\circ} 28^{\prime} 31^{\prime \prime}$ \\
\hline 08061500 & East Fork Trinity River near Rockwall, Tex. & 840 & $32^{\circ} 55^{\prime} 25^{\prime \prime}$ & $96^{\circ} 30^{\prime} 20^{\prime \prime}$ \\
\hline
\end{tabular}


Table 1. U.S. Geological Survey streamflow-gaging stations in Texas with at least 1 year of daily mean streamflow data—Continued.

\begin{tabular}{|c|c|c|c|c|}
\hline $\begin{array}{l}\text { USGS } \\
\text { station } \\
\text { no. }\end{array}$ & USGS station name & $\begin{array}{l}\text { Contributing } \\
\text { drainage } \\
\text { area } \\
\left(\mathrm{mi}^{2}\right)\end{array}$ & Latitude & Longitude \\
\hline 08061540 & Rowlett Creek near Sachse, Tex. & 120 & $32^{\circ} 57^{\prime} 35^{\prime \prime}$ & $96^{\circ} 36^{\prime} 51^{\prime \prime}$ \\
\hline 08061700 & Duck Creek near Garland, Tex. & 31.6 & $32^{\circ} 49^{\prime} 58^{\prime \prime}$ & $96^{\circ} 35^{\prime} 43^{\prime \prime}$ \\
\hline 08061750 & East Fork Trinity River near Forney, Tex. & 1,118 & $32^{\circ} 46^{\prime} 27^{\prime \prime}$ & $96^{\circ} 30^{\prime} 12^{\prime \prime}$ \\
\hline 08062000 & East Fork Trinity River near Crandall, Tex. & 1,256 & $32^{\circ} 38^{\prime} 19^{\prime \prime}$ & $96^{\circ} 29^{\prime} 06^{\prime \prime}$ \\
\hline 08062500 & Trinity River near Rosser, Tex. & 8,147 & $32^{\circ} 25^{\prime} 35^{\prime \prime}$ & $96^{\circ} 27^{\prime} 46^{\prime \prime}$ \\
\hline 08062650 & Cedar Creek Reservoir Spillway Outflow near Trinidad, Tex. & 1,007 & $32^{\circ} 14^{\prime} 16^{\prime \prime}$ & $96^{\circ} 08^{\prime} 36^{\prime \prime}$ \\
\hline 08062700 & Trinity River at Trinidad, Tex. & 8,538 & $32^{\circ} 08^{\prime} 05^{\prime \prime}$ & $96^{\circ} 06^{\prime} 20^{\prime \prime}$ \\
\hline 08063000 & Cedar Creek near Mabank, Tex. & 733 & $32^{\circ} 19^{\prime} 45^{\prime \prime}$ & $96^{\circ} 10^{\prime} 05^{\prime \prime}$ \\
\hline 08063003 & South Twin Creek near Eustace, Tex. & 27.4 & $32^{\circ} 19^{\prime} 18^{\prime \prime}$ & $96^{\circ} 01^{\prime} 43^{\prime \prime}$ \\
\hline 08063020 & Cedar Creek at Trinidad, Tex. & 1,011 & $32^{\circ} 09^{\prime} 24^{\prime \prime}$ & $96^{\circ} 03^{\prime} 45^{\prime \prime}$ \\
\hline 08063100 & Richland Creek near Dawson, Tex. & 333 & $31^{\circ} 56^{\prime} 18^{\prime \prime}$ & $96^{\circ} 40^{\prime} 52^{\prime \prime}$ \\
\hline 08063200 & Pin Oak Creek near Hubbard, Tex. & 17.6 & $31^{\circ} 48^{\prime} 01^{\prime \prime}$ & $96^{\circ} 43^{\prime} 02^{\prime \prime}$ \\
\hline 08063500 & Richland Creek near Richland, Tex. & 734 & $31^{\circ} 57^{\prime} 02^{\prime \prime}$ & $96^{\circ} 25^{\prime} 16^{\prime \prime}$ \\
\hline 08063800 & Waxahachie Creek near Bardwell, Tex. & 178 & $32^{\circ} 14^{\prime} 36^{\prime \prime}$ & $96^{\circ} 38^{\prime} 24^{\prime \prime}$ \\
\hline 08064100 & Chambers Creek near Rice, Tex. & 807 & $32^{\circ} 11^{\prime} 54^{\prime \prime}$ & $96^{\circ} 31^{\prime} 12^{\prime \prime}$ \\
\hline 08064500 & Chambers Creek near Corsicana, Tex. & 963 & $32^{\circ} 06^{\prime} 29^{\prime \prime}$ & $96^{\circ} 22^{\prime} 14^{\prime \prime}$ \\
\hline 08065700 & Caney Creek near Madisonville, Tex. & 112 & $30^{\circ} 56^{\prime} 12^{\prime \prime}$ & $95^{\circ} 56^{\prime} 07^{\prime \prime}$ \\
\hline 08065800 & Bedias Creek near Madisonville, Tex. & 321 & $30^{\circ} 53^{\prime} 05^{\prime \prime}$ & $95^{\circ} 46^{\prime} 40^{\prime \prime}$ \\
\hline 08066000 & Trinity River at Riverside, Tex. & 15,589 & $30^{\circ} 51^{\prime} 33^{\prime \prime}$ & $95^{\circ} 23^{\prime} 55^{\prime \prime}$ \\
\hline 08066100 & White Rock Creek near Trinity, Tex. & 222 & $31^{\circ} 03^{\prime} 06^{\prime \prime}$ & $95^{\circ} 22^{\prime} 40^{\prime \prime}$ \\
\hline 08066170 & Kickapoo Creek near Onalaska, Tex. & 57 & $30^{\circ} 54^{\prime} 25^{\prime \prime}$ & $95^{\circ} 05^{\prime} 18^{\prime \prime}$ \\
\hline 08066191 & Livingston Reservoir Outflow Weir near Goodrich, Tex. & 16,583 & $30^{\circ} 37^{\prime} 55^{\prime \prime}$ & $95^{\circ} 01^{\prime} 11^{\prime \prime}$ \\
\hline 08066200 & Long King Creek at Livingston, Tex. & 141 & $30^{\circ} 42^{\prime} 58^{\prime \prime}$ & $94^{\circ} 57^{\prime} 31^{\prime \prime}$ \\
\hline 08066250 & Trinity River near Goodrich, Tex. & 16,844 & $30^{\circ} 34^{\prime} 19^{\prime \prime}$ & $94^{\circ} 56^{\prime} 55^{\prime \prime}$ \\
\hline 08066300 & Menard Creek near Rye, Tex. & 152 & $30^{\circ} 28^{\prime} 53^{\prime \prime}$ & $94^{\circ} 46^{\prime} 47^{\prime \prime}$ \\
\hline 08066500 & Trinity River at Romayor, Tex. & 17,186 & $30^{\circ} 25^{\prime} 30^{\prime \prime}$ & $94^{\circ} 51^{\prime} 02^{\prime \prime}$ \\
\hline 08067000 & Trinity River at Liberty, Tex. & 17,468 & $30^{\circ} 03^{\prime} 27^{\prime \prime}$ & $94^{\circ} 49^{\prime} 05^{\prime \prime}$ \\
\hline 08067500 & Cedar Bayou near Crosby, Tex. & 64.9 & $29^{\circ} 58^{\prime} 21^{\prime \prime}$ & $94^{\circ} 59^{\prime} 08^{\prime \prime}$ \\
\hline 08067525 & Goose Creek at Baytown, Tex. & 15.8 & $29^{\circ} 46^{\prime} 14^{\prime \prime}$ & $94^{\circ} 59^{\prime} 58^{\prime \prime}$ \\
\hline 08067610 & Lake Conroe Outflow Weir near Conroe, Tex. & 445 & $30^{\circ} 21^{\prime} 23^{\prime \prime}$ & $95^{\circ} 33^{\prime} 37^{\prime \prime}$ \\
\hline 08067650 & West Fork San Jacinto River below Lake Conroe near Conroe, Tex. & 451 & $30^{\circ} 20^{\prime} 31^{\prime \prime}$ & $95^{\circ} 32^{\prime} 34^{\prime \prime}$ \\
\hline 08067700 & Caney Creek near Dobbin, Tex. & 40.4 & $30^{\circ} 21^{\prime} 13^{\prime \prime}$ & $95^{\circ} 48^{\prime} 35^{\prime \prime}$ \\
\hline 08067900 & Lake Creek near Conroe, Tex. & 291 & $30^{\circ} 15^{\prime} 12^{\prime \prime}$ & $95^{\circ} 34^{\prime} 43^{\prime \prime}$ \\
\hline
\end{tabular}




\section{Statewide Analysis of the Drainage-Area Ratio Method for 34 Streamflow Percentile Ranges in Texas}

Table 1. U.S. Geological Survey streamflow-gaging stations in Texas with at least 1 year of daily mean streamflow data—Continued.

\begin{tabular}{|c|c|c|c|c|}
\hline $\begin{array}{l}\text { USGS } \\
\text { station } \\
\text { no. }\end{array}$ & USGS station name & $\begin{array}{l}\text { Contributing } \\
\text { drainage } \\
\text { area } \\
\left(\mathrm{mi}^{2}\right)\end{array}$ & Latitude & Longitude \\
\hline 08068000 & West Fork San Jacinto River near Conroe, Tex. & 828 & $30^{\circ} 14^{\prime} 40^{\prime \prime}$ & $95^{\circ} 27^{\prime} 25^{\prime \prime}$ \\
\hline 08068090 & West Fork San Jacinto River above Lake Houston near Porter, Tex. & 962 & $30^{\circ} 05^{\prime} 09^{\prime \prime}$ & $95^{\circ} 17^{\prime} 59^{\prime \prime}$ \\
\hline 08068275 & Spring Creek near Tomball, Tex. & 186 & $30^{\circ} 07^{\prime} 11^{\prime \prime}$ & $95^{\circ} 38^{\prime} 45^{\prime \prime}$ \\
\hline 08068390 & Bear Branch at Research Boulevard, The Woodlands, Tex. & 15.4 & $30^{\circ} 11^{\prime} 26^{\prime \prime}$ & $95^{\circ} 29^{\prime} 28^{\prime \prime}$ \\
\hline 08068400 & Panther Branch at Gosling Road, The Woodlands, Tex. & 25.9 & $30^{\circ} 11^{\prime} 31^{\prime \prime}$ & $95^{\circ} 29^{\prime} 01^{\prime \prime}$ \\
\hline 08068450 & Panther Branch near Spring, Tex. & 34.5 & $30^{\circ} 07 ' 51^{\prime \prime}$ & $95^{\circ} 28^{\prime} 52^{\prime \prime}$ \\
\hline 08068500 & Spring Creek near Spring, Tex. & 409 & $30^{\circ} 06^{\prime} 37^{\prime \prime}$ & $95^{\circ} 26^{\prime} 10^{\prime \prime}$ \\
\hline 08068520 & Spring Creek at Spring, Tex. & 419 & $30^{\circ} 05^{\prime} 31^{\prime \prime}$ & $95^{\circ} 24^{\prime} 21^{\prime \prime}$ \\
\hline 08068800 & Cypress Creek at Grant Road near Cypress, Tex. & 214 & $29^{\circ} 58^{\prime} 24^{\prime \prime}$ & $95^{\circ} 35^{\prime} 54^{\prime \prime}$ \\
\hline 08068900 & Cypress Creek at Stuebner-Airline Road near Westfield, Tex. & 248 & $30^{\circ} 00^{\prime} 23^{\prime \prime}$ & $95^{\circ} 30^{\prime} 42^{\prime \prime}$ \\
\hline 08069000 & Cypress Creek near Westfield, Tex. & 285 & $30^{\circ} 02^{\prime} 08^{\prime \prime}$ & $95^{\circ} 25^{\prime} 43^{\prime \prime}$ \\
\hline 08069500 & West Fork San Jacinto River near Humble, Tex. & 1,741 & $30^{\circ} 01^{\prime} 37^{\prime \prime}$ & $95^{\circ} 15^{\prime} 28^{\prime \prime}$ \\
\hline 08070000 & East Fork San Jacinto River near Cleveland, Tex. & 325 & $30^{\circ} 20^{\prime} 11^{\prime \prime}$ & $95^{\circ} 06^{\prime} 14^{\prime \prime}$ \\
\hline 08070200 & East Fork San Jacinto River near New Caney, Tex. & 388 & $30^{\circ} 08^{\prime} 43^{\prime \prime}$ & $95^{\circ} 07^{\prime} 27^{\prime \prime}$ \\
\hline 08070500 & Caney Creek near Splendora, Tex. & 105 & $30^{\circ} 15^{\prime} 34^{\prime \prime}$ & $95^{\circ} 18^{\prime} 08^{\prime \prime}$ \\
\hline 08071000 & Peach Creek at Splendora, Tex. & 117 & $30^{\circ} 13^{\prime} 57^{\prime \prime}$ & $95^{\circ} 10^{\prime} 05^{\prime \prime}$ \\
\hline 08073600 & Buffalo Bayou at West Belt Drive at Houston, Tex. & 307 & $29^{\circ} 45^{\prime} 43^{\prime \prime}$ & $95^{\circ} 33^{\prime} 27^{\prime \prime}$ \\
\hline 08073700 & Buffalo Bayou at Piney Point, Tex. & 317 & $29^{\circ} 44^{\prime} 48^{\prime \prime}$ & $95^{\circ} 31^{\prime 2} 24^{\prime \prime}$ \\
\hline 08074000 & Buffalo Bayou at Houston, Tex. & 336 & $29^{\circ} 45^{\prime} 36^{\prime \prime}$ & $95^{\circ} 24 ' 30^{\prime \prime}$ \\
\hline 08074020 & Whiteoak Bayou at Alabonson Road at Houston, Tex. & 34.5 & $29^{\circ} 52^{\prime} 14^{\prime \prime}$ & $95^{\circ} 28^{\prime} 49^{\prime \prime}$ \\
\hline 08074150 & Cole Creek at Deihl Road, Houston, Tex. & 7.5 & $29^{\circ} 51^{\prime} 04^{\prime \prime}$ & $95^{\circ} 29^{\prime} 16^{\prime \prime}$ \\
\hline 08074250 & Brickhouse Gully at Costa Rica Street, Houston, Tex. & 11.4 & $29^{\circ} 49^{\prime} 40^{\prime \prime}$ & $95^{\circ} 28^{\prime} 09^{\prime \prime}$ \\
\hline 08074500 & Whiteoak Bayou at Houston, Tex. & 86.3 & $29^{\circ} 46^{\prime} 30^{\prime \prime}$ & $95^{\circ} 23^{\prime} 49^{\prime \prime}$ \\
\hline 08074760 & Brays Bayou at Alief, Tex. & 12.9 & $29^{\circ} 42^{\prime} 39^{\prime \prime}$ & $95^{\circ} 35^{\prime} 13^{\prime \prime}$ \\
\hline 08074780 & Keegans Bayou at Keegan Road near Houston, Tex. & 8.63 & $29^{\circ} 39^{\prime} 55^{\prime \prime}$ & $95^{\circ} 35^{\prime} 42^{\prime \prime}$ \\
\hline 08074800 & Keegans Bayou at Roark Road near Houston, Tex. & 12.7 & $29^{\circ} 39^{\prime} 23^{\prime \prime}$ & $95^{\circ} 33^{\prime} 43^{\prime \prime}$ \\
\hline 08074810 & Brays Bayou at Gessner Drive, Houston, Tex. & 52.5 & $29^{\circ} 40^{\prime} 21^{\prime \prime}$ & $95^{\circ} 31^{\prime} 41^{\prime \prime}$ \\
\hline 08075000 & Brays Bayou at Houston, Tex. & 94.9 & $29^{\circ} 41^{\prime} 49^{\prime \prime}$ & $95^{\circ} 24^{\prime} 43^{\prime \prime}$ \\
\hline 08075400 & Sims Bayou at Hiram Clarke Street, Houston, Tex. & 20.2 & $29^{\circ} 37^{\prime} 07^{\prime \prime}$ & $95^{\circ} 26^{\prime} 45^{\prime \prime}$ \\
\hline 08075500 & Sims Bayou at Houston, Tex. & 63 & $29^{\circ} 40^{\prime} 27^{\prime \prime}$ & $95^{\circ} 17^{\prime} 21 "$ \\
\hline 08075650 & Berry Bayou at Forest Oaks Street, Houston, Tex. & 10.7 & $29^{\circ} 40^{\prime} 35^{\prime \prime}$ & $95^{\circ} 14 ' 37 "$ \\
\hline 08075730 & Vince Bayou at Pasadena, Tex. & 8.26 & $29^{\circ} 41^{\prime} 40^{\prime \prime}$ & $95^{\circ} 12^{\prime} 58^{\prime \prime}$ \\
\hline 08075770 & Hunting Bayou at Interstate Highway 610, Houston, Tex. & 16.1 & $29^{\circ} 47^{\prime} 35^{\prime \prime}$ & $95^{\circ} 16^{\prime} 04^{\prime \prime}$ \\
\hline
\end{tabular}


Table 1. U.S. Geological Survey streamflow-gaging stations in Texas with at least 1 year of daily mean streamflow data—Continued.

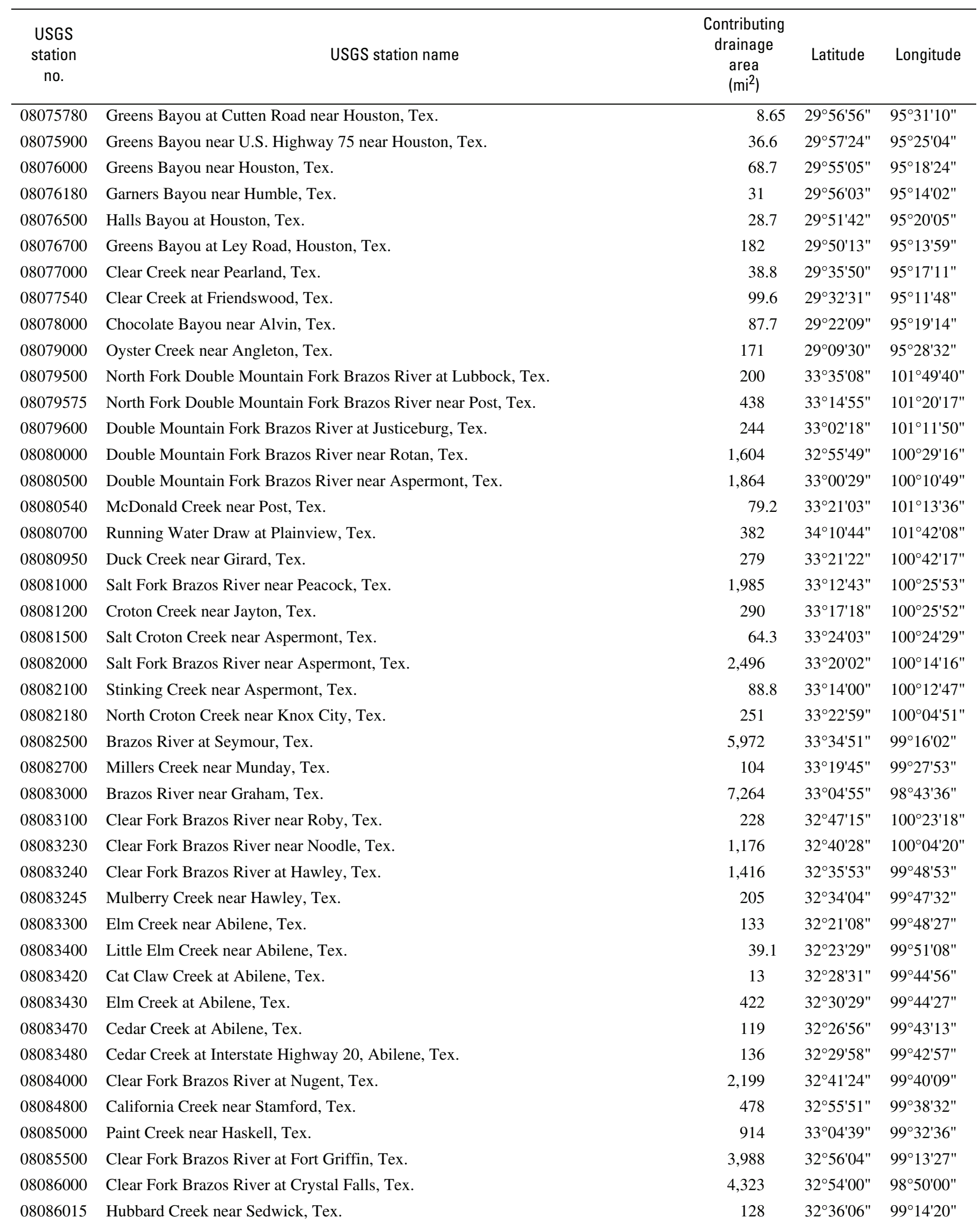


Table 1. U.S. Geological Survey streamflow-gaging stations in Texas with at least 1 year of daily mean streamflow data—Continued.

\begin{tabular}{|c|c|c|c|c|}
\hline $\begin{array}{c}\text { USGS } \\
\text { station } \\
\text { no. }\end{array}$ & USGS station name & $\begin{array}{c}\text { Contributing } \\
\text { drainage } \\
\text { area } \\
\left(\mathrm{mi}^{2}\right)\end{array}$ & Latitude & Longitude \\
\hline 08086050 & Deep Creek at Moran, Tex. & 235 & $32^{\circ} 33^{\prime} 33^{\prime \prime}$ & $99^{\circ} 10^{\prime} 11^{\prime \prime}$ \\
\hline 08086100 & Hubbard Creek near Albany, Tex. & 454 & $32^{\circ} 41^{\prime} 21^{\prime \prime}$ & $99^{\circ} 09^{\prime} 52^{\prime \prime}$ \\
\hline 08086120 & Salt Prong Hubbard Creek at U.S. Highway 380 near Albany, Tex. & 65.2 & $32^{\circ} 41^{\prime} 01^{\prime \prime}$ & $99^{\circ} 16^{\prime} 05^{\prime \prime}$ \\
\hline 08086150 & North Fork Hubbard Creek near Albany, Tex. & 39.3 & $32^{\circ} 42^{\prime} 27^{\prime \prime}$ & $99^{\circ} 16^{\prime} 29^{\prime \prime}$ \\
\hline 08086200 & Salt Prong Hubbard Creek near Albany, Tex. & 115 & $32^{\circ} 42^{\prime} 02^{\prime \prime}$ & $99^{\circ} 12^{\prime} 42^{\prime \prime}$ \\
\hline 08086210 & Snailum Creek near Albany, Tex. & 22.9 & $32^{\circ} 43^{\prime} 15^{\prime \prime}$ & $99^{\circ} 10^{\prime} 30^{\prime \prime}$ \\
\hline 08086212 & Hubbard Creek below Albany, Tex. & 613 & $32^{\circ} 43^{\prime} 58^{\prime \prime}$ & $99^{\circ} 08^{\prime} 25^{\prime \prime}$ \\
\hline 08086235 & Battle Creek near Moran, Tex. & 108 & $32^{\circ} 33^{\prime} 10^{\prime \prime}$ & $99^{\circ} 06 ' 32^{\prime \prime}$ \\
\hline 08086260 & Pecan Creek near Eolian, Tex. & 26.4 & $32^{\circ} 35^{\prime} 01^{\prime \prime}$ & $99^{\circ} 01^{\prime} 57^{\prime \prime}$ \\
\hline 08086290 & Big Sandy Creek above Breckenridge, Tex. & 280 & $32^{\circ} 38^{\prime} 54^{\prime \prime}$ & $99^{\circ} 00^{\prime} 15^{\prime \prime}$ \\
\hline 08086500 & Hubbard Creek near Breckenridge, Tex. & 1,089 & $32^{\circ} 50^{\prime} 13^{\prime \prime}$ & $98^{\circ} 56^{\prime} 52^{\prime \prime}$ \\
\hline 08087300 & Clear Fork Brazos River at Eliasville, Tex. & 5,697 & $32^{\circ} 57^{\prime} 36^{\prime \prime}$ & $98^{\circ} 45^{\prime} 59^{\prime \prime}$ \\
\hline 08088000 & Brazos River near South Bend, Tex. & 13,107 & $33^{\circ} 011^{\prime} 27^{\prime \prime}$ & $98^{\circ} 38^{\prime} 37^{\prime \prime}$ \\
\hline 08088100 & Salt Creek at Olney, Tex. & 11.8 & $33^{\circ} 22^{\prime} 13^{\prime \prime}$ & $98^{\circ} 44^{\prime} 40^{\prime \prime}$ \\
\hline 08088200 & Salt Creek near Newcastle, Tex. & 120 & $33^{\circ} 13^{\prime} 00^{\prime \prime}$ & $98^{\circ} 38^{\prime} 55^{\prime \prime}$ \\
\hline 08088300 & Briar Creek near Graham, Tex. & 24.2 & $33^{\circ} 12^{\prime} 43^{\prime \prime}$ & $98^{\circ} 37^{\prime} 06^{\prime \prime}$ \\
\hline 08088450 & Big Cedar Creek near Ivan, Tex. & 97 & $32^{\circ} 49^{\prime} 39^{\prime \prime}$ & $98^{\circ} 43^{\prime} 25^{\prime \prime}$ \\
\hline 08088600 & Brazos River at Morris Sheppard Dam near Graford, Tex. & 14,030 & $32^{\circ} 52^{\prime} 19^{\prime \prime}$ & $98^{\circ} 25^{\prime} 32^{\prime \prime}$ \\
\hline 08088610 & Brazos River near Graford, Tex. & 14,030 & $32^{\circ} 51^{\prime} 29^{\prime \prime}$ & $98^{\circ} 24^{\prime} 41^{\prime \prime}$ \\
\hline 08089000 & Brazos River near Palo Pinto, Tex. & 14,245 & $32^{\circ} 51^{\prime} 45^{\prime \prime}$ & $98^{\circ} 18^{\prime} 08^{\prime \prime}$ \\
\hline 08090500 & Palo Pinto Creek near Santo, Tex. & 573 & $32^{\circ} 37^{\prime} 51^{\prime \prime}$ & $98^{\circ} 10^{\prime} 50^{\prime \prime}$ \\
\hline 08090800 & Brazos River near Dennis, Tex. & 15,671 & $32^{\circ} 36^{\prime} 56^{\prime \prime}$ & $97^{\circ} 55^{\prime} 32^{\prime \prime}$ \\
\hline 08091000 & Brazos River near Glen Rose, Tex. & 16,252 & $32^{\circ} 15^{\prime} 32^{\prime \prime}$ & $97^{\circ} 42^{\prime} 08^{\prime \prime}$ \\
\hline 08091500 & Paluxy River at Glen Rose, Tex. & 410 & $32^{\circ} 13^{\prime} 53^{\prime \prime}$ & $97^{\circ} 46^{\prime} 37^{\prime \prime}$ \\
\hline 08091750 & Squaw Creek near Glen Rose, Tex. & 70.3 & $32^{\circ} 16^{\prime} 12^{\prime \prime}$ & $97^{\circ} 43^{\prime} 56^{\prime \prime}$ \\
\hline 08092000 & Nolan River at Blum, Tex. & 282 & $32^{\circ} 09^{\prime} 02^{\prime \prime}$ & $97^{\circ} 24^{\prime} 09^{\prime \prime}$ \\
\hline 08092600 & Brazos River at Whitney Dam near Whitney, Tex. & 17,623 & $31^{\circ} 52^{\prime} 00^{\prime \prime}$ & $97^{\circ} 22^{\prime} 00^{\prime \prime}$ \\
\hline 08093100 & Brazos River near Aquilla, Tex. & 17,678 & $31^{\circ} 48^{\prime} 44^{\prime \prime}$ & $97^{\circ} 17^{\prime} 51^{\prime \prime}$ \\
\hline 08093250 & Hackberry Creek at Hillsboro, Tex. & 57.9 & $32^{\circ} 00^{\prime} 20^{\prime \prime}$ & $97^{\circ} 08^{\prime} 59^{\prime \prime}$ \\
\hline 08093360 & Aquilla Creek above Aquilla, Tex. & 255 & $31^{\circ} 53^{\prime} 43^{\prime \prime}$ & $97^{\circ} 12^{\prime} 10^{\prime \prime}$ \\
\hline 08093400 & Cobb Creek near Abbott, Tex. & 12.4 & $31^{\circ} 55^{\prime} 11^{\prime \prime}$ & $97^{\circ} 05^{\prime} 57^{\prime \prime}$ \\
\hline 08093500 & Aquilla Creek near Aquilla, Tex. & 308 & $31^{\circ} 50^{\prime} 40 "$ & $97^{\circ} 12^{\prime} 04^{\prime \prime}$ \\
\hline 08093700 & North Bosque River at Stephenville, Tex. & 95.9 & $32^{\circ} 12^{\prime} 56^{\prime \prime}$ & $98^{\circ} 11^{\prime} 55^{\prime \prime}$ \\
\hline 08094800 & North Bosque River at Hico, Tex. & 359 & $31^{\circ} 58^{\prime} 41^{\prime \prime}$ & $98^{\circ} 02^{\prime} 04^{\prime \prime}$ \\
\hline 08095000 & North Bosque River near Clifton, Tex. & 968 & $31^{\circ} 47^{\prime} 09^{\prime \prime}$ & $97^{\circ} 34^{\prime} 04^{\prime \prime}$ \\
\hline 08095200 & North Bosque River at Valley Mills, Tex. & 1,146 & $31^{\circ} 40^{\prime} 10^{\prime \prime}$ & $97^{\circ} 28^{\prime} 09^{\prime \prime}$ \\
\hline 08095300 & Middle Bosque River near McGregor, Tex. & 182 & 31³0'33" & $97^{\circ} 21^{\prime} 56^{\prime \prime}$ \\
\hline 08095400 & Hog Creek near Crawford, Tex. & 78.2 & $31^{\circ} 33^{\prime} 20^{\prime \prime}$ & $97^{\circ} 21^{\prime} 22^{\prime \prime}$ \\
\hline 08095500 & South Bosque River near Speegleville, Tex. & 386 & $31^{\circ} 31^{\prime} 00^{\prime \prime}$ & $97^{\circ} 15^{\prime} 00^{\prime \prime}$ \\
\hline 08095600 & Bosque River near Waco, Tex. & 1,656 & $31^{\circ} 36^{\prime} 04^{\prime \prime}$ & $97^{\circ} 11^{\prime} 36^{\prime \prime}$ \\
\hline 08096500 & Brazos River at Waco, Tex. & 19,993 & $31^{\circ} 32^{\prime} 09^{\prime \prime}$ & $97^{\circ} 04^{\prime} 23^{\prime \prime}$ \\
\hline 08097500 & Brazos River near Marlin, Tex. & 20,645 & $31^{\circ} 17^{\prime} 18^{\prime \prime}$ & $96^{\circ} 58^{\prime} 10^{\prime \prime}$ \\
\hline 08098000 & Deer Creek at Chilton, Tex. & 84.5 & $31^{\circ} 15^{\prime} 58^{\prime \prime}$ & $97^{\circ} 03^{\prime} 30^{\prime \prime}$ \\
\hline
\end{tabular}


Table 1. U.S. Geological Survey streamflow-gaging stations in Texas with at least 1 year of daily mean streamflow data—Continued.

\begin{tabular}{|c|c|c|c|c|}
\hline $\begin{array}{l}\text { USGS } \\
\text { station } \\
\text { no. }\end{array}$ & USGS station name & $\begin{array}{l}\text { Contributing } \\
\text { drainage } \\
\text { area } \\
\left(\mathrm{mi}^{2}\right)\end{array}$ & Latitude & Longitude \\
\hline 08098290 & Brazos River near Highbank, Tex. & 20,870 & $31^{\circ} 08^{\prime} 02^{\prime \prime}$ & $96^{\circ} 49^{\prime 2} 29^{\prime \prime}$ \\
\hline 08098300 & Little Pond Creek near Burlington, Tex. & 23 & $31^{\circ} 01^{\prime} 35^{\prime \prime}$ & $96^{\circ} 59^{\prime} 17^{\prime \prime}$ \\
\hline 08099100 & Leon River near De Leon, Tex. & 479 & $32^{\circ} 10^{\prime} 25^{\prime \prime}$ & $98^{\circ} 31^{\prime} 58^{\prime \prime}$ \\
\hline 08099500 & Leon River near Hasse, Tex. & 1,261 & $31^{\circ} 57^{\prime} 28^{\prime \prime}$ & $98^{\circ} 27^{\prime} 32^{\prime \prime}$ \\
\hline 08100000 & Leon River near Hamilton, Tex. & 1,891 & $31^{\circ} 47^{\prime} 19^{\prime \prime}$ & $98^{\circ} 07^{\prime} 16^{\prime \prime}$ \\
\hline 08100500 & Leon River at Gatesville, Tex. & 2,342 & $31^{\circ} 25^{\prime} 58^{\prime \prime}$ & $97^{\circ} 45^{\prime} 42^{\prime \prime}$ \\
\hline 08101000 & Cowhouse Creek at Pidcoke, Tex. & 455 & $31^{\circ} 17^{\prime} 05^{\prime \prime}$ & $97^{\circ} 53^{\prime} 05^{\prime \prime}$ \\
\hline 08101500 & Cowhouse Creek near Killeen, Tex. & 667 & $31^{\circ} 12^{\prime} 21^{\prime \prime}$ & $97^{\circ} 42^{\prime} 55^{\prime \prime}$ \\
\hline 08103900 & South Fork Rocky Creek near Briggs, Tex. & 33.3 & $30^{\circ} 54^{\prime} 41^{\prime \prime}$ & $98^{\circ} 02^{\prime} 12^{\prime \prime}$ \\
\hline 08104000 & Lampasas River at Youngsport, Tex. & 1,240 & $30^{\circ} 57^{\prime} 26^{\prime \prime}$ & $97^{\circ} 42^{\prime} 30^{\prime \prime}$ \\
\hline 08104100 & Lampasas River near Belton, Tex. & 1,321 & $31^{\circ} 00^{\prime} 06^{\prime \prime}$ & $97^{\circ} 29^{\prime} 32^{\prime \prime}$ \\
\hline 08104310 & Salado Creek below Salado Springs at Salado, Tex. & 136 & $30^{\circ} 57^{\prime} 07^{\prime \prime}$ & $97^{\circ} 31^{\prime} 26^{\prime \prime}$ \\
\hline 08104500 & Little River near Little River, Tex. & 5,228 & $30^{\circ} 57^{\prime} 59^{\prime \prime}$ & $97^{\circ} 20^{\prime} 45^{\prime \prime}$ \\
\hline 08104700 & North Fork San Gabriel River near Georgetown, Tex. & 248 & $30^{\circ} 39^{\prime} 42^{\prime \prime}$ & $97^{\circ} 42^{\prime} 40^{\prime \prime}$ \\
\hline 08104900 & South Fork San Gabriel River at Georgetown, Tex. & 133 & $30^{\circ} 37^{\prime} 32^{\prime \prime}$ & $97^{\circ} 41^{\prime} 27^{\prime \prime}$ \\
\hline 08105000 & San Gabriel River at Georgetown, Tex. & 405 & $30^{\circ} 39^{\prime} 14^{\prime \prime}$ & $97^{\circ} 39^{\prime} 18^{\prime \prime}$ \\
\hline 08106300 & Brushy Creek near Rockdale, Tex. & 505 & $30^{\circ} 41^{\prime} 38^{\prime \prime}$ & $97^{\circ} 04^{\prime} 42^{\prime \prime}$ \\
\hline 08106310 & San Gabriel River near Rockdale, Tex. & 1,359 & $30^{\circ} 43^{\prime} 39^{\prime \prime}$ & $97^{\circ} 02^{\prime} 19^{\prime \prime}$ \\
\hline 08106350 & Little River near Rockdale, Tex. & 6,959 & $30^{\circ} 45^{\prime} 38^{\prime \prime}$ & $97^{\circ} 00^{\prime} 49^{\prime \prime}$ \\
\hline 08106500 & Little River at Cameron, Tex. & 7,065 & $30^{\circ} 50^{\prime} 06^{\prime \prime}$ & $96^{\circ} 56^{\prime} 47^{\prime \prime}$ \\
\hline 08107000 & Big Elm Creek near Temple, Tex. & 74.7 & $31^{\circ} 02^{\prime} 58^{\prime \prime}$ & $97^{\circ} 14^{\prime} 08^{\prime \prime}$ \\
\hline 08107500 & Big Elm Creek near Buckholts, Tex. & 171 & $30^{\circ} 56^{\prime} 50^{\prime \prime}$ & $97^{\circ} 06^{\prime} 14^{\prime \prime}$ \\
\hline 08108000 & North Elm Creek near Ben Arnold, Tex. & 32.2 & $30^{\circ} 57^{\prime} 00^{\prime \prime}$ & $97^{\circ} 03^{\prime} 00^{\prime \prime}$ \\
\hline 08108200 & North Elm Creek near Cameron, Tex. & 44.8 & $30^{\circ} 55^{\prime} 52^{\prime \prime}$ & $97^{\circ} 01^{\prime} 13^{\prime \prime}$ \\
\hline 08108700 & Brazos River at State Highway 21 near Bryan, Tex. & 29,483 & $30^{\circ} 37^{\prime} 36^{\prime \prime}$ & $96^{\circ} 32^{\prime} 38^{\prime \prime}$ \\
\hline 08109000 & Brazos River near Bryan, Tex. & 29,949 & $30^{\circ} 36^{\prime} 50^{\prime \prime}$ & $96^{\circ} 29^{\prime} 11^{\prime \prime}$ \\
\hline 08109700 & Middle Yegua Creek near Dime Box, Tex. & 236 & $30^{\circ} 20^{\prime} 21^{\prime \prime}$ & $96^{\circ} 54^{\prime} 16^{\prime \prime}$ \\
\hline 08109800 & East Yegua Creek near Dime Box, Tex. & 244 & $30^{\circ} 24^{\prime} 26^{\prime \prime}$ & $96^{\circ} 49^{\prime} 02^{\prime \prime}$ \\
\hline 08110000 & Yegua Creek near Somerville, Tex. & 1,009 & $30^{\circ} 19^{\prime} 18^{\prime \prime}$ & $96^{\circ} 30^{\prime} 26^{\prime \prime}$ \\
\hline 08110100 & Davidson Creek near Lyons, Tex. & 195 & $30^{\circ} 25^{\prime} 10^{\prime \prime}$ & $96^{\circ} 32 ' 24^{\prime \prime}$ \\
\hline 08110200 & Brazos River at Washington, Tex. & 31,626 & $30^{\circ} 21^{\prime} 40^{\prime \prime}$ & $96^{\circ} 09^{\prime} 18^{\prime \prime}$ \\
\hline 08110325 & Navasota River above Groesbeck, Tex. & 239 & $31^{\circ} 34^{\prime} 27^{\prime \prime}$ & $96^{\circ} 31^{\prime} 14^{\prime \prime}$ \\
\hline 08110400 & Navasota River near Groesbeck, Tex. & 311 & $31^{\circ} 30^{\prime} 44^{\prime \prime}$ & $96^{\circ} 27^{\prime} 01^{\prime \prime}$ \\
\hline
\end{tabular}


Table 1. U.S. Geological Survey streamflow-gaging stations in Texas with at least 1 year of daily mean streamflow data—Continued.

\begin{tabular}{|c|c|c|c|c|}
\hline $\begin{array}{c}\text { USGS } \\
\text { station } \\
\text { no. }\end{array}$ & USGS station name & $\begin{array}{l}\text { Contributing } \\
\text { drainage } \\
\text { area } \\
\left(\mathrm{mi}^{2}\right)\end{array}$ & Latitude & Longitude \\
\hline 08110430 & Big Creek near Freestone, Tex. & 97.2 & $31^{\circ} 30^{\prime} 24^{\prime \prime}$ & $96^{\circ} 19^{\prime} 28^{\prime \prime}$ \\
\hline 08110500 & Navasota River near Easterly, Tex. & 968 & $31^{\circ} 10^{\prime} 12^{\prime \prime}$ & $96^{\circ} 17^{\prime} 51^{\prime \prime}$ \\
\hline 08110800 & Navasota River at Old Spanish Road near Bryan, Tex. & 1,287 & $30^{\circ} 58^{\prime} 25^{\prime \prime}$ & $96^{\circ} 14^{\prime} 29^{\prime \prime}$ \\
\hline 08111000 & Navasota River near Bryan, Tex. & 1,454 & $30^{\circ} 52^{\prime} 10^{\prime \prime}$ & $96^{\circ} 11^{\prime} 32^{\prime \prime}$ \\
\hline 08111010 & Navasota River near College Station, Tex. & 1,809 & $30^{\circ} 36^{\prime} 26^{\prime \prime}$ & $96^{\circ} 10^{\prime} 53^{\prime \prime}$ \\
\hline 08111025 & Burton Creek at Villa Maria Road at Bryan, Tex. & 1.33 & $30^{\circ} 38^{\prime} 47^{\prime \prime}$ & $96^{\circ} 20^{\prime} 58^{\prime \prime}$ \\
\hline 08111050 & Hudson Creek near Bryan, Tex. & 1.94 & $30^{\circ} 39^{\prime} 37^{\prime \prime}$ & $96^{\circ} 17^{\prime} 58^{\prime \prime}$ \\
\hline 08111500 & Brazos River near Hempstead, Tex. & 34,314 & $30^{\circ} 07^{\prime} 44^{\prime \prime}$ & $96^{\circ} 11^{\prime} 15^{\prime \prime}$ \\
\hline 08111700 & Mill Creek near Bellville, Tex. & 376 & $29^{\circ} 52^{\prime} 51^{\prime \prime}$ & $96^{\circ} 12^{\prime} 18^{\prime \prime}$ \\
\hline 08114000 & Brazos River at Richmond, Tex. & 35,541 & $29^{\circ} 34^{\prime} 56^{\prime \prime}$ & $95^{\circ} 45^{\prime} 27^{\prime \prime}$ \\
\hline 08114500 & Brazos River near Juliff, Tex. & 35,623 & $29^{\circ} 27^{\prime} 19^{\prime \prime}$ & $95^{\circ} 31^{\prime} 58^{\prime \prime}$ \\
\hline 08115000 & Big Creek near Needville, Tex. & 42.8 & $29^{\circ} 28^{\prime} 35^{\prime \prime}$ & $95^{\circ} 48^{\prime} 45^{\prime \prime}$ \\
\hline 08115500 & Fairchild Creek near Needville, Tex. & 26.2 & $29^{\circ} 26^{\prime} 45^{\prime \prime}$ & $95^{\circ} 45^{\prime} 41^{\prime \prime}$ \\
\hline 08116000 & Big Creek near Guy, Tex. & 116 & $29^{\circ} 24^{\prime} 45^{\prime \prime}$ & $95^{\circ} 42^{\prime} 36^{\prime \prime}$ \\
\hline 08116400 & Dry Creek near Rosenberg, Tex. & 8.65 & $29^{\circ} 30^{\prime} 42^{\prime \prime}$ & $95^{\circ} 44^{\prime} 48^{\prime \prime}$ \\
\hline 08116500 & Dry Creek near Richmond, Tex. & 12.2 & $29^{\circ} 30^{\prime} 19^{\prime \prime}$ & $95^{\circ} 42^{\prime} 41^{\prime \prime}$ \\
\hline 08116650 & Brazos River near Rosharon, Tex. & 35,773 & $29^{\circ} 20^{\prime} 58^{\prime \prime}$ & $95^{\circ} 34^{\prime} 56^{\prime \prime}$ \\
\hline 08117500 & San Bernard River near Boling, Tex. & 727 & $29^{\circ} 18^{\prime} 48^{\prime \prime}$ & $95^{\circ} 53^{\prime} 37^{\prime \prime}$ \\
\hline 08117900 & Big Boggy Creek near Wadsworth, Tex. & 10.3 & $28^{\circ} 48^{\prime} 26^{\prime \prime}$ & $95^{\circ} 57^{\prime} 02^{\prime \prime}$ \\
\hline 08117995 & Colorado River near Gail, Tex. & 498 & $32^{\circ} 37^{\prime} 43^{\prime \prime}$ & $101^{\circ} 17^{\prime} 06^{\prime \prime}$ \\
\hline 08118500 & Bull Creek near Ira, Tex. & 26.3 & $32^{\circ} 36^{\prime} 00^{\prime \prime}$ & $101^{\circ} 05^{\prime} 38^{\prime \prime}$ \\
\hline 08119000 & Bluff Creek near Ira, Tex. & 42.6 & $32^{\circ} 35^{\prime} 29^{\prime \prime}$ & $101^{\circ} 03^{\prime} 02^{\prime \prime}$ \\
\hline 08119500 & Colorado River near Ira, Tex. & 1,112 & $32^{\circ} 32^{\prime} 18^{\prime \prime}$ & $101^{\circ} 03^{\prime} 12^{\prime \prime}$ \\
\hline 08120500 & Deep Creek near Dunn, Tex. & 188 & $32^{\circ} 34^{\prime} 25^{\prime \prime}$ & $100^{\circ} 54^{\prime} 27^{\prime \prime}$ \\
\hline 08120700 & Colorado River near Cuthbert, Tex. & 1,531 & $32^{\circ} 28^{\prime} 38^{\prime \prime}$ & $100^{\circ} 56^{\prime} 58^{\prime \prime}$ \\
\hline 08121000 & Colorado River at Colorado City, Tex. & 1,585 & $32^{\circ} 23^{\prime} 33^{\prime \prime}$ & $100^{\circ} 52^{\prime} 42^{\prime \prime}$ \\
\hline 08121500 & Morgan Creek near Westbrook, Tex. & 230 & $32^{\circ} 23^{\prime} 42^{\prime \prime}$ & $101^{\circ} 01^{\prime} 32^{\prime \prime}$ \\
\hline 08122000 & Graze Creek near Westbrook, Tex. & 21.7 & $32^{\circ} 35^{\prime} 03^{\prime \prime}$ & $101^{\circ} 01^{\prime} 10^{\prime \prime}$ \\
\hline 08122500 & Morgan Creek near Colorado City, Tex. & 270 & $32^{\circ} 23^{\prime} 17^{\prime \prime}$ & $100^{\circ} 56^{\prime} 59^{\prime \prime}$ \\
\hline 08123500 & Champion Creek near Colorado City, Tex. & 177 & $32^{\circ} 19^{\prime} 01^{\prime \prime}$ & $100^{\circ} 49^{\prime} 28^{\prime \prime}$ \\
\hline 08123650 & Beals Creek above Big Spring, Tex. & 1,505 & $32^{\circ} 15^{\prime} 01^{\prime \prime}$ & $101^{\circ} 29^{\prime} 26^{\prime \prime}$ \\
\hline 08123700 & Beals Creek at Big Spring, Tex. & 1,527 & $32^{\circ} 15^{\prime} 45^{\prime \prime}$ & $101^{\circ} 26^{\prime} 30^{\prime \prime}$ \\
\hline 08123720 & Beals Creek near Coahoma, Tex. & 1,569 & $32^{\circ} 14^{\prime} 56^{\prime \prime}$ & $101^{\circ} 21^{\prime} 42^{\prime \prime}$ \\
\hline 08123800 & Beals Creek near Westbrook, Tex. & 1,988 & $32^{\circ} 11^{\prime} 57^{\prime \prime}$ & $101^{\circ} 00^{\prime} 49^{\prime \prime}$ \\
\hline 08123850 & Colorado River above Silver, Tex. & 4,650 & $32^{\circ} 03^{\prime} 13^{\prime \prime}$ & $100^{\circ} 45^{\prime} 42^{\prime \prime}$ \\
\hline 08123900 & Colorado River near Silver, Tex. & 4,737 & $32^{\circ} 01^{\prime} 10^{\prime \prime}$ & $100^{\circ} 44^{\prime} 08^{\prime \prime}$ \\
\hline 08124000 & Colorado River at Robert Lee, Tex. & 5,047 & $31^{\circ} 53^{\prime} 07^{\prime \prime}$ & $100^{\circ} 28^{\prime} 49^{\prime \prime}$ \\
\hline 08126380 & Colorado River near Ballinger, Tex. & 6,098 & $31^{\circ} 42^{\prime} 55^{\prime \prime}$ & $100^{\circ} 01^{\prime} 34^{\prime \prime}$ \\
\hline 08126500 & Colorado River at Ballinger, Tex. & 6,160 & $31^{\circ} 43^{\prime} 58^{\prime \prime}$ & $99^{\circ} 57^{\prime} 13^{\prime \prime}$ \\
\hline 08127000 & Elm Creek at Ballinger, Tex. & 450 & $31^{\circ} 44^{\prime} 57^{\prime \prime}$ & $99^{\circ} 566^{\prime} 51^{\prime \prime}$ \\
\hline 08128000 & South Concho River at Christoval, Tex. & 354 & $31^{\circ} 11^{\prime} 13^{\prime \prime}$ & $100^{\circ} 30^{\prime} 06^{\prime \prime}$ \\
\hline 08128400 & Middle Concho River above Tankersley, Tex. & 1,116 & $31^{\circ} 25^{\prime} 38^{\prime \prime}$ & $100^{\circ} 42^{\prime} 39^{\prime \prime}$ \\
\hline 08128500 & Middle Concho River near Tankersley, Tex. & 1,685 & $31^{\circ} 22^{\prime} 35^{\prime \prime}$ & $100^{\circ} 36^{\prime} 50^{\prime \prime}$ \\
\hline
\end{tabular}


Table 1. U.S. Geological Survey streamflow-gaging stations in Texas with at least 1 year of daily mean streamflow data—Continued.

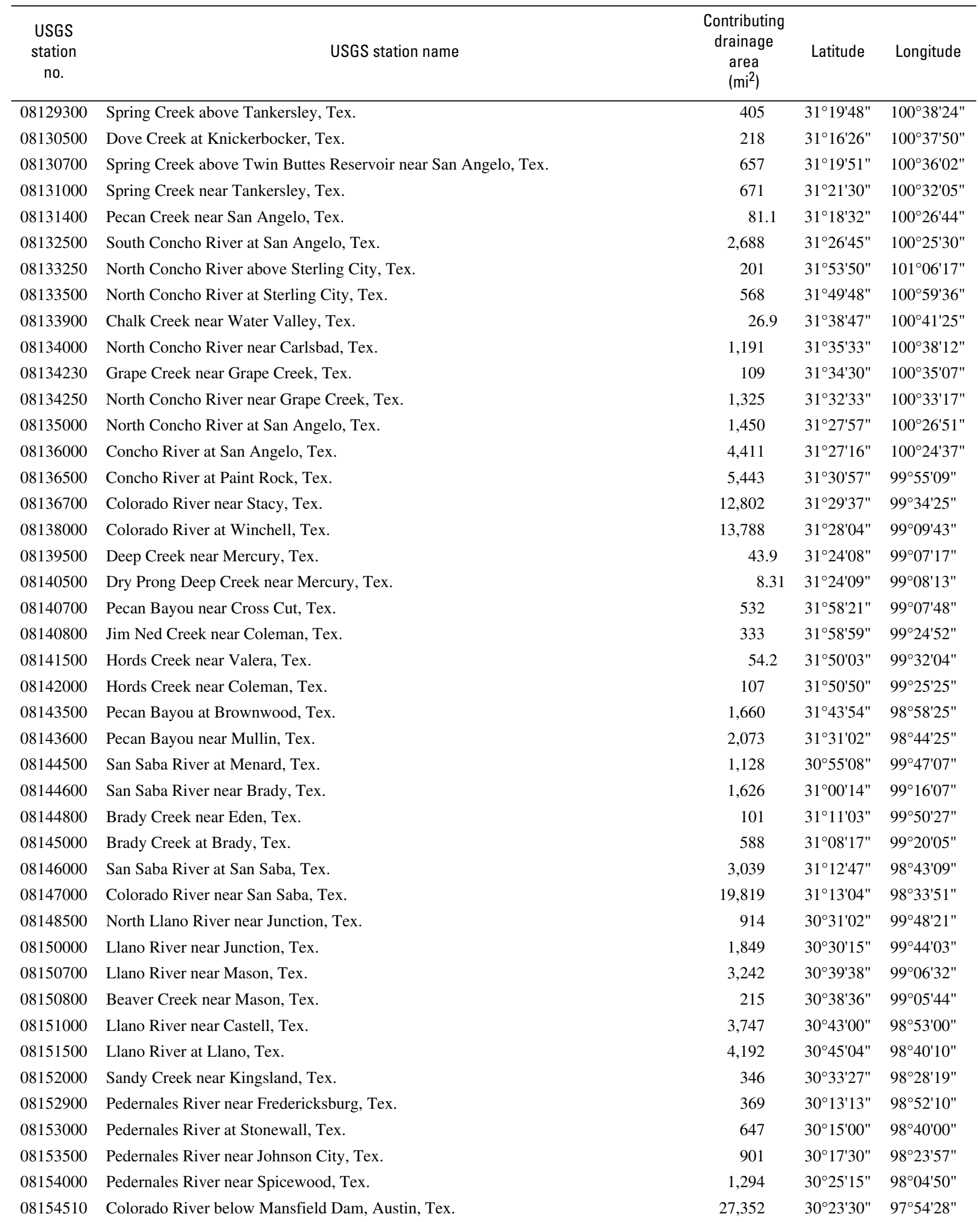


Table 1. U.S. Geological Survey streamflow-gaging stations in Texas with at least 1 year of daily mean streamflow data—Continued.

\begin{tabular}{|c|c|c|c|c|}
\hline $\begin{array}{c}\text { USGS } \\
\text { station } \\
\text { no. }\end{array}$ & USGS station name & $\begin{array}{l}\text { Contributing } \\
\text { drainage } \\
\text { area } \\
\left(\mathrm{mi}^{2}\right)\end{array}$ & Latitude & Longitude \\
\hline 08154700 & Bull Creek at Loop 360 near Austin, Tex. & 22.3 & $30^{\circ} 22^{\prime} 19^{\prime \prime}$ & $97^{\circ} 47^{\prime} 04^{\prime \prime}$ \\
\hline 08155200 & Barton Creek at State Highway 71 near Oak Hill, Tex. & 89.7 & $30^{\circ} 17^{\prime} 46^{\prime \prime}$ & $97^{\circ} 55^{\prime} 31^{\prime \prime}$ \\
\hline 08155240 & Barton Creek at Lost Creek Boulevard near Austin, Tex. & 107 & $30^{\circ} 16^{\prime} 26^{\prime \prime}$ & $97^{\circ} 50^{\prime} 40^{\prime \prime}$ \\
\hline 08155300 & Barton Creek at Loop 360, Austin, Tex. & 116 & $30^{\circ} 14^{\prime} 40^{\prime \prime}$ & $97^{\circ} 48^{\prime} 07^{\prime \prime}$ \\
\hline 08155400 & Barton Creek above Barton Springs at Austin, Tex. & 125 & $30^{\circ} 15^{\prime} 48^{\prime \prime}$ & $97^{\circ} 46^{\prime} 19^{\prime \prime}$ \\
\hline 08156700 & Shoal Creek at Northwest Park at Austin, Tex. & 6.52 & $30^{\circ} 20^{\prime} 50^{\prime \prime}$ & $97^{\circ} 44^{\prime} 41^{\prime \prime}$ \\
\hline 08156800 & Shoal Creek at West 12th Street, Austin, Tex. & 12.3 & $30^{\circ} 16^{\prime} 35^{\prime \prime}$ & $97^{\circ} 45^{\prime} 00^{\prime \prime}$ \\
\hline 08157000 & Waller Creek at 38th Street, Austin, Tex. & 2.31 & $30^{\circ} 17^{\prime} 49^{\prime \prime}$ & $97^{\circ} 43^{\prime} 36^{\prime \prime}$ \\
\hline 08158000 & Colorado River at Austin, Tex. & 27,606 & $30^{\circ} 14^{\prime} 40^{\prime \prime}$ & $97^{\circ} 41^{\prime} 39^{\prime \prime}$ \\
\hline 08158050 & Boggy Creek at U.S. Highway 183, Austin, Tex. & 13.1 & $30^{\circ} 15^{\prime} 47^{\prime \prime}$ & $97^{\circ} 40^{\prime} 20^{\prime \prime}$ \\
\hline 08158600 & Walnut Creek at Webberville Road, Austin, Tex. & 51.3 & $30^{\circ} 16^{\prime} 59^{\prime \prime}$ & $97^{\circ} 39^{\prime} 17^{\prime \prime}$ \\
\hline 08158700 & Onion Creek near Driftwood, Tex. & 124 & $30^{\circ} 04^{\prime} 58^{\prime \prime}$ & $98^{\circ} 00^{\prime} 27^{\prime \prime}$ \\
\hline 08158800 & Onion Creek at Buda, Tex. & 166 & $30^{\circ} 05^{\prime} 09^{\prime \prime}$ & $97^{\circ} 50^{\prime} 52^{\prime \prime}$ \\
\hline 08158810 & Bear Creek below Farm to Market Road 1826 near Driftwood, Tex. & 12.2 & $30^{\circ} 09^{\prime} 19^{\prime \prime}$ & $97^{\circ} 566^{\prime \prime} 23^{\prime \prime}$ \\
\hline 08158840 & Slaughter Creek at Farm to Market Road 1826 near Austin, Tex. & 8.24 & $30^{\circ} 12^{\prime} 32^{\prime \prime}$ & $97^{\circ} 54^{\prime} 11 "$ \\
\hline 08158920 & Williamson Creek at Oak Hill, Tex. & 6.3 & $30^{\circ} 14^{\prime} 06^{\prime \prime}$ & $97^{\circ} 51^{\prime} 36^{\prime \prime}$ \\
\hline 08159170 & Big Sandy Creek near Elgin, Tex. & 63.8 & $30^{\circ} 15^{\prime} 54^{\prime \prime}$ & $97^{\circ} 19^{\prime} 39^{\prime \prime}$ \\
\hline 08159200 & Colorado River at Bastrop, Tex. & 28,576 & $30^{\circ} 06^{\prime} 16^{\prime \prime}$ & $97^{\circ} 19^{\prime} 09^{\prime \prime}$ \\
\hline 08159500 & Colorado River at Smithville, Tex. & 28,968 & $30^{\circ} 00^{\prime} 45^{\prime \prime}$ & $97^{\circ} 09^{\prime} 42^{\prime \prime}$ \\
\hline 08160400 & Colorado River above La Grange, Tex. & 29,471 & $29^{\circ} 54^{\prime} 44^{\prime \prime}$ & $96^{\circ} 54^{\prime} 13^{\prime \prime}$ \\
\hline 08160500 & Colorado River at La Grange, Tex. & 27,550 & $29^{\circ} 53^{\prime} 45^{\prime \prime}$ & $96^{\circ} 52^{\prime} 15^{\prime \prime}$ \\
\hline 08160700 & Colorado River above Columbus, Tex. & 29,910 & $29^{\circ} 43^{\prime} 09^{\prime \prime}$ & $96^{\circ} 34^{\prime} 16^{\prime \prime}$ \\
\hline 08160800 & Redgate Creek near Columbus, Tex. & 17.3 & $29^{\circ} 47^{\prime} 56^{\prime \prime}$ & $96^{\circ} 31^{\prime} 55^{\prime \prime}$ \\
\hline 08161000 & Colorado River at Columbus, Tex. & 30,237 & $29^{\circ} 42^{\prime} 22^{\prime \prime}$ & $96^{\circ} 32^{\prime} 12^{\prime \prime}$ \\
\hline 08162000 & Colorado River at Wharton, Tex. & 30,600 & $29^{\circ} 18^{\prime} 32^{\prime \prime}$ & $96^{\circ} 06^{\prime} 13^{\prime \prime}$ \\
\hline 08162500 & Colorado River near Bay City, Tex. & 30,837 & $28^{\circ} 58^{\prime} 26^{\prime \prime}$ & $96^{\circ} 00^{\prime} 44^{\prime \prime}$ \\
\hline 08162600 & Tres Palacios River near Midfield, Tex. & 145 & $28^{\circ} 55^{\prime} 40^{\prime \prime}$ & $96^{\circ} 10^{\prime} 15^{\prime \prime}$ \\
\hline 08164000 & Lavaca River near Edna, Tex. & 817 & $28^{\circ} 57^{\prime} 35^{\prime \prime}$ & $96^{\circ} 41^{\prime} 10^{\prime \prime}$ \\
\hline 08164300 & Navidad River near Hallettsville, Tex. & 332 & $29^{\circ} 28^{\prime} 00^{\prime \prime}$ & $96^{\circ} 48^{\prime} 45^{\prime \prime}$ \\
\hline 08164350 & Navidad River near Speaks, Tex. & 437 & $29^{\circ} 19^{\prime} 18^{\prime \prime}$ & $96^{\circ} 42^{\prime} 32^{\prime \prime}$ \\
\hline 08164370 & Navidad River at Morales, Tex. & 549 & $29^{\circ} 08^{\prime} 07^{\prime \prime}$ & $96^{\circ} 44^{\prime} 39^{\prime \prime}$ \\
\hline 08164390 & Navidad River at Strane Park near Edna, Tex. & 579 & $29^{\circ} 03^{\prime} 55^{\prime \prime}$ & $96^{\circ} 40^{\prime} 26^{\prime \prime}$ \\
\hline 08164450 & Sandy Creek near Ganado, Tex. & 289 & $29^{\circ} 09^{\prime} 36^{\prime \prime}$ & $96^{\circ} 32^{\prime} 46^{\prime \prime}$ \\
\hline
\end{tabular}


Table 1. U.S. Geological Survey streamflow-gaging stations in Texas with at least 1 year of daily mean streamflow data—Continued.

\begin{tabular}{|c|c|c|c|c|}
\hline $\begin{array}{l}\text { USGS } \\
\text { station } \\
\text { no. }\end{array}$ & USGS station name & $\begin{array}{l}\text { Contributing } \\
\text { drainage } \\
\text { area } \\
\left(\mathrm{mi}^{2}\right)\end{array}$ & Latitude & Longitude \\
\hline 08164500 & Navidad River near Ganado, Tex. & 1,062 & $29^{\circ} 01^{\prime} 32^{\prime \prime}$ & $96^{\circ} 33^{\prime} 08^{\prime \prime}$ \\
\hline 08164503 & West Mustang Creek near Ganado, Tex. & 178 & $29^{\circ} 04^{\prime} 17^{\prime \prime}$ & $96^{\circ} 28^{\prime} 01^{\prime \prime}$ \\
\hline 08164504 & East Mustang Creek near Louise, Tex. & 90.8 & $29^{\circ} 04^{\prime} 14^{\prime \prime}$ & $96^{\circ} 25^{\prime} 01^{\prime \prime}$ \\
\hline 08164800 & Placedo Creek near Placedo, Tex. & 68.3 & $28^{\circ} 43^{\prime} 30^{\prime \prime}$ & $96^{\circ} 46^{\prime} 07^{\prime \prime}$ \\
\hline 08165300 & North Fork Guadalupe River near Hunt, Tex. & 169 & $30^{\circ} 03^{\prime} 50^{\prime \prime}$ & $99^{\circ} 23^{\prime} 12^{\prime \prime}$ \\
\hline 08165500 & Guadalupe River at Hunt, Tex. & 288 & $30^{\circ} 04^{\prime} 11^{\prime \prime}$ & $99^{\circ} 19^{\prime} 17^{\prime \prime}$ \\
\hline 08166000 & Johnson Creek near Ingram, Tex. & 114 & $30^{\circ} 06^{\prime} 00^{\prime \prime}$ & $99^{\circ} 16^{\prime} 58^{\prime \prime}$ \\
\hline 08166140 & Guadalupe River above Bear Creek at Kerrville, Tex. & 494 & $30^{\circ} 04^{\prime} 10^{\prime \prime}$ & $99^{\circ} 11^{\prime} 42^{\prime \prime}$ \\
\hline 08167500 & Guadalupe River near Spring Branch, Tex. & 1,315 & $29^{\circ} 51^{\prime} 37^{\prime \prime}$ & $98^{\circ} 23^{\prime} 00^{\prime \prime}$ \\
\hline 08167600 & Rebecca Creek near Spring Branch, Tex. & 10.9 & $29^{\circ} 55^{\prime} 06^{\prime \prime}$ & $98^{\circ} 22^{\prime} 10^{\prime \prime}$ \\
\hline 08167800 & Guadalupe River at Sattler, Tex. & 1,436 & $29^{\circ} 51^{\prime} 32^{\prime \prime}$ & $98^{\circ} 10^{\prime} 47^{\prime \prime}$ \\
\hline 08168500 & Guadalupe River above Comal River at New Braunfels, Tex. & 1,518 & $29^{\circ} 42^{\prime} 53^{\prime \prime}$ & $98^{\circ} 06^{\prime} 35^{\prime \prime}$ \\
\hline 08169000 & Comal River at New Braunfels, Tex. & 130 & $29^{\circ} 42^{\prime} 21^{\prime \prime}$ & $98^{\circ} 07^{\prime} 20^{\prime \prime}$ \\
\hline 08169500 & Guadalupe River at New Braunfels, Tex. & 1,652 & $29^{\circ} 41^{\prime} 52^{\prime \prime}$ & $98^{\circ} 06^{\prime} 23^{\prime \prime}$ \\
\hline 08170500 & San Marcos River at San Marcos, Tex. & 48.9 & $29^{\circ} 53^{\prime} 20^{\prime \prime}$ & $97^{\circ} 56^{\prime} 02^{\prime \prime}$ \\
\hline 08171000 & Blanco River at Wimberley, Tex. & 355 & $29^{\circ} 59^{\prime} 39^{\prime \prime}$ & $98^{\circ} 05^{\prime} 19^{\prime \prime}$ \\
\hline 08173900 & Guadalupe River at Gonzales, Tex. & 3,490 & $29^{\circ} 29^{\prime} 03^{\prime \prime}$ & $97^{\circ} 27^{\prime} 00^{\prime \prime}$ \\
\hline 08174600 & Peach Creek below Dilworth, Tex. & 460 & $29^{\circ} 28^{\prime} 26^{\prime \prime}$ & $97^{\circ} 18^{\prime} 59^{\prime \prime}$ \\
\hline 08175000 & Sandies Creek near Westhoff, Tex. & 549 & $29^{\circ} 12^{\prime} 54^{\prime \prime}$ & $97^{\circ} 26{ }^{\prime} 57^{\prime \prime}$ \\
\hline 08175800 & Guadalupe River at Cuero, Tex. & 4,934 & $29^{\circ} 05^{\prime} 25^{\prime \prime}$ & $97^{\circ} 19^{\prime} 46^{\prime \prime}$ \\
\hline 08176000 & Guadalupe River below Cuero, Tex. & 4,923 & $29^{\circ} 03^{\prime} 05^{\prime \prime}$ & $97^{\circ} 15^{\prime} 52^{\prime \prime}$ \\
\hline 08176500 & Guadalupe River at Victoria, Tex. & 5,198 & $28^{\circ} 47^{\prime} 34^{\prime \prime}$ & $97^{\circ} 00^{\prime} 46^{\prime \prime}$ \\
\hline 08176550 & Fifteenmile Creek near Weser, Tex. & 167 & $28^{\circ} 53^{\prime} 51^{\prime \prime}$ & $97^{\circ} 21^{\prime} 17^{\prime \prime}$ \\
\hline 08176900 & Coleto Creek at Arnold Road near Schroeder, Tex. & 357 & $28^{\circ} 51^{\prime} 41^{\prime \prime}$ & $97^{\circ} 13^{\prime} 34^{\prime \prime}$ \\
\hline 08176990 & Coleto Creek Reservoir Inflow (Guadalupe Diversion) near Schroeder, Tex. & 357 & $28^{\circ} 50^{\prime} 21^{\prime \prime}$ & $97^{\circ} 11^{\prime} 20^{\prime \prime}$ \\
\hline 08177000 & Coleto Creek near Schroeder, Tex. & 369 & $28^{\circ} 49^{\prime} 53^{\prime \prime}$ & $97^{\circ} 11^{\prime} 10^{\prime \prime}$ \\
\hline 08177300 & Perdido Creek at Farm to Market Road 622 near Fannin, Tex. & 28 & $28^{\circ} 45^{\prime} 05^{\prime \prime}$ & $97^{\circ} 19^{\prime} 01^{\prime \prime}$ \\
\hline 08177500 & Coleto Creek near Victoria, Tex. & 514 & $28^{\circ} 43^{\prime} 51^{\prime \prime}$ & $97^{\circ} 08^{\prime} 18^{\prime \prime}$ \\
\hline 08177700 & Olmos Creek at Dresden Drive, San Antonio, Tex. & 21.2 & $29^{\circ} 29^{\prime} 56^{\prime \prime}$ & $98^{\circ} 30^{\prime} 36^{\prime \prime}$ \\
\hline 08177860 & San Antonio River at Woodlawn Ave, San Antonio, Tex. & 36.4 & $29^{\circ} 27^{\prime} 04^{\prime \prime}$ & $98^{\circ} 28^{\prime} 42^{\prime \prime}$ \\
\hline 08178000 & San Antonio River at San Antonio, Tex. & 41.8 & $29^{\circ} 24^{\prime} 34^{\prime \prime}$ & $98^{\circ} 29^{\prime} 41^{\prime \prime}$ \\
\hline 08178050 & San Antonio River at Mitchell Street, San Antonio, Tex. & 42.4 & $29^{\circ} 23^{\prime} 34^{\prime \prime}$ & $98^{\circ} 29^{\prime} 40^{\prime \prime}$ \\
\hline 08178500 & San Pedro Creek at Furnish Street, San Antonio, Tex. & 2.64 & $29^{\circ} 24^{\prime} 22^{\prime \prime}$ & $98^{\circ} 30^{\prime} 38^{\prime \prime}$ \\
\hline
\end{tabular}


Table 1. U.S. Geological Survey streamflow-gaging stations in Texas with at least 1 year of daily mean streamflow data—Continued.

\begin{tabular}{|c|c|c|c|c|}
\hline $\begin{array}{c}\text { USGS } \\
\text { station } \\
\text { no. }\end{array}$ & USGS station name & $\begin{array}{c}\text { Contributing } \\
\text { drainage } \\
\text { area } \\
\left(\mathrm{mi}^{2}\right)\end{array}$ & Latitude & Longitude \\
\hline 08178565 & San Antonio River at Loop 410 at San Antonio, Tex. & 125 & $29^{\circ} 19^{\prime} 19^{\prime \prime}$ & $98^{\circ} 27^{\prime} 00^{\prime \prime}$ \\
\hline 08178585 & Salado Creek at Wilderness Road at San Antonio, Tex. & 23 & $29^{\circ} 37^{\prime} 50^{\prime \prime}$ & $98^{\circ} 33^{\prime} 55^{\prime \prime}$ \\
\hline 08178700 & Salado Creek at Loop 410 at San Antonio, Tex. & 137 & $29^{\circ} 30^{\prime} 57^{\prime \prime}$ & $98^{\circ} 25^{\prime} 51^{\prime \prime}$ \\
\hline 08178800 & Salado Creek at Loop 13 at San Antonio, Tex. & 189 & $29^{\circ} 21^{\prime} 25^{\prime \prime}$ & $98^{\circ} 24^{\prime} 45^{\prime \prime}$ \\
\hline 08178880 & Medina River at Bandera, Tex. & 328 & $29^{\circ} 43 ' 25^{\prime \prime}$ & $99^{\circ} 04^{\prime} 11^{\prime \prime}$ \\
\hline 08179000 & Medina River near Pipe Creek, Tex. & 474 & $29^{\circ} 40^{\prime} 31^{\prime \prime}$ & $98^{\circ} 58^{\prime} 33^{\prime \prime}$ \\
\hline 08179100 & Red Bluff Creek near Pipe Creek, Tex. & 56.3 & $29^{\circ} 40^{\prime} 51^{\prime \prime}$ & $98^{\circ} 57^{\prime} 19^{\prime \prime}$ \\
\hline 08179520 & Medina River below Medina Lake near San Antonio, Tex. & 635 & $29^{\circ} 32^{\prime} 02^{\prime \prime}$ & $98^{\circ} 56^{\prime} 06^{\prime \prime}$ \\
\hline 08180500 & Medina River near Riomedina, Tex. & 650 & $29^{\circ} 29^{\prime} 53^{\prime \prime}$ & $98^{\circ} 54^{\prime} 16^{\prime \prime}$ \\
\hline 08180640 & Medina River at La Coste, Tex. & 805 & $29^{\circ} 19^{\prime} 26^{\prime \prime}$ & $98^{\circ} 48^{\prime} 46^{\prime \prime}$ \\
\hline 08180700 & Medina River near Macdona, Tex. & 885 & $29^{\circ} 20^{\prime} 05^{\prime \prime}$ & $98^{\circ} 41^{\prime 22 "}$ \\
\hline 08180750 & Medio Creek at Pearsall Road at San Antonio, Tex. & 47.9 & $29^{\circ} 19^{\prime} 40^{\prime \prime}$ & $98^{\circ} 38^{\prime} 19^{\prime \prime}$ \\
\hline 08180800 & Medina River near Somerset, Tex. & 967 & $29^{\circ} 15^{\prime} 43^{\prime \prime}$ & $98^{\circ} 34^{\prime} 52^{\prime \prime}$ \\
\hline 08181400 & Helotes Creek at Helotes, Tex. & 15 & $29^{\circ} 34^{\prime} 42^{\prime \prime}$ & $98^{\circ} 41^{\prime 2} 29^{\prime \prime}$ \\
\hline 08181410 & Ranch Creek near Helotes, Tex. & .39 & $29^{\circ} 36^{\prime} 06^{\prime \prime}$ & $98^{\circ} 43^{\prime} 26^{\prime \prime}$ \\
\hline 08181450 & Leon Creek Tributary at Kelly Air Force Base, Tex. & 1.19 & $29^{\circ} 23^{\prime} 12^{\prime \prime}$ & $98^{\circ} 36^{\prime} 00^{\prime \prime}$ \\
\hline 08181480 & Leon Creek at Interstate Highway 35 at San Antonio, Tex. & 219 & $29^{\circ} 19^{\prime} 47^{\prime \prime}$ & $98^{\circ} 35^{\prime} 02^{\prime \prime}$ \\
\hline 08181500 & Medina River at San Antonio, Tex. & 1,317 & $29^{\circ} 15^{\prime} 50^{\prime \prime}$ & $98^{\circ} 29^{\prime} 26^{\prime \prime}$ \\
\hline 08181800 & San Antonio River near Elmendorf, Tex. & 1,743 & $29^{\circ} 13^{\prime} 19^{\prime \prime}$ & $98^{\circ} 21^{\prime} 20^{\prime \prime}$ \\
\hline 08182500 & Calaveras Creek near Elemendorf, Tex. & 77.2 & $29^{\circ} 15^{\prime} 38^{\prime \prime}$ & $98^{\circ} 17^{\prime} 34^{\prime \prime}$ \\
\hline 08183000 & San Antonio River at Calaveras, Tex. & 1,786 & $29^{\circ} 12^{\prime} 54^{\prime \prime}$ & $98^{\circ} 15^{\prime} 39^{\prime \prime}$ \\
\hline 08183500 & San Antonio River near Falls City, Tex. & 2,113 & $28^{\circ} 57^{\prime} 05^{\prime \prime}$ & $98^{\circ} 03^{\prime} 50^{\prime \prime}$ \\
\hline 08183850 & Cibolo Creek at Interstate Highway 10 above Boerne, Tex. & 29 & $29^{\circ} 48^{\prime} 52^{\prime \prime}$ & $98^{\circ} 45^{\prime} 12^{\prime \prime}$ \\
\hline 08183900 & Cibolo Creek near Boerne, Tex. & 68.4 & $29^{\circ} 46^{\prime} 26^{\prime \prime}$ & $98^{\circ} 41^{\prime} 50^{\prime \prime}$ \\
\hline 08184000 & Cibolo Creek near Bulverde, Tex. & 198 & $29^{\circ} 43^{\prime} 33^{\prime \prime}$ & $98^{\circ} 25^{\prime} 37^{\prime \prime}$ \\
\hline 08184500 & Cibolo Creek above Bracken, Tex. & 250 & $29^{\circ} 40^{\prime} 30^{\prime \prime}$ & $98^{\circ} 23^{\prime} 00^{\prime \prime}$ \\
\hline 08185000 & Cibolo Creek at Selma, Tex. & 274 & $29^{\circ} 35^{\prime} 38^{\prime \prime}$ & $98^{\circ} 18^{\prime} 39^{\prime \prime}$ \\
\hline 08185500 & Cibolo Creek at Sutherland Springs, Tex. & 665 & $29^{\circ} 16^{\prime} 47^{\prime \prime}$ & $98^{\circ} 03^{\prime} 10^{\prime \prime}$ \\
\hline 08186000 & Cibolo Creek near Falls City, Tex. & 827 & $29^{\circ} 00^{\prime} 50^{\prime \prime}$ & $97^{\circ} 55^{\prime} 48^{\prime \prime}$ \\
\hline 08186500 & Ecleto Creek near Runge, Tex. & 239 & $28^{\circ} 55^{\prime} 12^{\prime \prime}$ & $97^{\circ} 46^{\prime} 19^{\prime \prime}$ \\
\hline 08187500 & Escondido Creek at Kenedy, Tex. & 72.4 & $28^{\circ} 49^{\prime} 11^{\prime \prime}$ & $97^{\circ} 51^{\prime} 32^{\prime \prime}$ \\
\hline 08188500 & San Antonio River at Goliad, Tex. & 3,921 & $28^{\circ} 38^{\prime} 58^{\prime \prime}$ & $97^{\circ} 23^{\prime} 04^{\prime \prime}$ \\
\hline 08189200 & Copano Creek near Refugio, Tex. & 87.8 & $28^{\circ} 18^{\prime} 12^{\prime \prime}$ & $97^{\circ} 06^{\prime} 44^{\prime \prime}$ \\
\hline 08189300 & Medio Creek near Beeville, Tex. & 204 & $28^{\circ} 28^{\prime} 58^{\prime \prime}$ & $97^{\circ} 39^{\prime} 23^{\prime \prime}$ \\
\hline 08189500 & Mission River at Refugio, Tex. & 690 & $28^{\circ} 17^{\prime} 30^{\prime \prime}$ & $97^{\circ} 16^{\prime} 44^{\prime \prime}$ \\
\hline 08189700 & Aransas River near Skidmore, Tex. & 247 & $28^{\circ} 16^{\prime} 56^{\prime \prime}$ & $97^{\circ} 37^{\prime} 14^{\prime \prime}$ \\
\hline 08189800 & Chiltipin Creek at Sinton, Tex. & 128 & $28^{\circ} 02^{\prime} 48^{\prime \prime}$ & $97^{\circ} 30^{\prime} 13^{\prime \prime}$ \\
\hline 08190000 & Nueces River at Laguna, Tex. & 737 & $29^{\circ} 25^{\prime} 42^{\prime \prime}$ & $99^{\circ} 59^{\prime} 49^{\prime \prime}$ \\
\hline 08190500 & West Nueces River near Brackettville, Tex. & 694 & $29^{\circ} 28^{\prime} 21^{\prime \prime}$ & $100^{\circ} 14^{\prime} 10^{\prime \prime}$ \\
\hline 08191500 & Nueces River near Uvalde, Tex. & 1,833 & $29^{\circ} 11^{\prime} 44^{\prime \prime}$ & $99^{\circ} 53^{\prime} 45^{\prime \prime}$ \\
\hline 08192000 & Nueces River below Uvalde, Tex. & 1,861 & $29^{\circ} 07^{\prime} 25^{\prime \prime}$ & $99^{\circ} 53^{\prime} 40^{\prime \prime}$ \\
\hline 08192500 & Nueces River near Cinonia, Tex. & 2,102 & $28^{\circ} 47^{\prime} 00^{\prime \prime}$ & $99^{\circ} 50^{\prime} 00^{\prime \prime}$ \\
\hline 08193000 & Nueces River near Asherton, Tex. & 4,082 & $28^{\circ} 30^{\prime} 00^{\prime \prime}$ & $99^{\circ} 40^{\prime} 54^{\prime \prime}$ \\
\hline
\end{tabular}


Table 1. U.S. Geological Survey streamflow-gaging stations in Texas with at least 1 year of daily mean streamflow data—Continued.

\begin{tabular}{|c|c|c|c|c|}
\hline $\begin{array}{c}\text { USGS } \\
\text { station } \\
\text { no. }\end{array}$ & USGS station name & $\begin{array}{l}\text { Contributing } \\
\text { drainage } \\
\text { area } \\
\left(\mathrm{mi}^{2}\right)\end{array}$ & Latitude & Longitude \\
\hline 08194000 & Nueces River at Cotulla, Tex. & 5,171 & $28^{\circ} 25^{\prime} 34^{\prime \prime}$ & $99^{\circ} 14^{\prime} 23^{\prime \prime}$ \\
\hline 08194200 & San Casimiro Creek near Freer, Tex. & 469 & $27^{\circ} 57^{\prime} 53^{\prime \prime}$ & $98^{\circ} 58^{\prime} 00^{\prime \prime}$ \\
\hline 08194500 & Nueces River near Tilden, Tex. & 8,093 & $28^{\circ} 18^{\prime} 31^{\prime \prime}$ & $98^{\circ} 33^{\prime} 25^{\prime \prime}$ \\
\hline 08194600 & Nueces River at Simmons, Tex. & 8,561 & $28^{\circ} 25^{\prime} 16^{\prime \prime}$ & $98^{\circ} 17^{\prime} 03^{\prime \prime}$ \\
\hline 08195000 & Frio River at Concan, Tex. & 389 & $29^{\circ} 29^{\prime} 18^{\prime \prime}$ & $99^{\circ} 42^{\prime} 16^{\prime \prime}$ \\
\hline 08196000 & Dry Frio River near Reagan Wells, Tex. & 126 & $29^{\circ} 30^{\prime} 16^{\prime \prime}$ & $99^{\circ} 462^{\prime \prime}$ \\
\hline 08196500 & Dry Frio River at Knippa, Tex. & 179 & $29^{\circ} 17^{\prime} 30^{\prime \prime}$ & $99^{\circ} 39^{\prime} 30^{\prime \prime}$ \\
\hline 08197500 & Frio River below Dry Frio River near Uvalde, Tex. & 631 & $29^{\circ} 14^{\prime} 44^{\prime \prime}$ & $99^{\circ} 40^{\prime} 27^{\prime \prime}$ \\
\hline 08198000 & Sabinal River near Sabinal, Tex. & 206 & $29^{\circ} 29^{\prime} 27^{\prime \prime}$ & $99^{\circ} 29^{\prime} 33^{\prime \prime}$ \\
\hline 08198500 & Sabinal River at Sabinal, Tex. & 241 & $29^{\circ} 18^{\prime} 05^{\prime \prime}$ & $99^{\circ} 28^{\prime} 46^{\prime \prime}$ \\
\hline 08199700 & Frio River near Frio Town, Tex. & 1,460 & $29^{\circ} 05^{\prime} 08^{\prime \prime}$ & $99^{\circ} 24^{\prime} 30^{\prime \prime}$ \\
\hline 08200000 & Hondo Creek near Tarpley, Tex. & 95.6 & $29^{\circ} 34^{\prime} 10^{\prime \prime}$ & $99^{\circ} 14^{\prime} 47^{\prime \prime}$ \\
\hline 08200500 & Hondo Creek near Hondo, Tex. & 132 & $29^{\circ} 27^{\prime} 05^{\prime \prime}$ & $99^{\circ} 11^{\prime} 07^{\prime \prime}$ \\
\hline 08200700 & Hondo Creek at King Waterhole near Hondo, Tex. & 149 & $29^{\circ} 23^{\prime} 26^{\prime \prime}$ & $99^{\circ} 09^{\prime} 04^{\prime \prime}$ \\
\hline 08201500 & Seco Creek at Miller Ranch near Utopia, Tex. & 45 & $29^{\circ} 34^{\prime} 23^{\prime \prime}$ & $99^{\circ} 24^{\prime} 10^{\prime \prime}$ \\
\hline 08202000 & Seco Creek near Utopia, Tex. & 53.2 & $29^{\circ} 33^{\prime} 01^{\prime \prime}$ & $99^{\circ} 24^{\prime} 22^{\prime \prime}$ \\
\hline 08202500 & Seco Creek near D'Hanis, Tex. & 87.4 & $29^{\circ} 29^{\prime} 20^{\prime \prime}$ & $99^{\circ} 23^{\prime} 16^{\prime \prime}$ \\
\hline 08202700 & Seco Creek at Rowe Ranch near D'Hanis, Tex. & 168 & $29^{\circ} 22^{\prime} 14^{\prime \prime}$ & $99^{\circ} 17^{\prime} 15^{\prime \prime}$ \\
\hline 08204005 & Leona River near Uvalde, Tex. & 132 & $29^{\circ} 09^{\prime} 15^{\prime \prime}$ & $99^{\circ} 44^{\prime} 35^{\prime \prime}$ \\
\hline 08204500 & Leona River near Divot, Tex. & 565 & $28^{\circ} 47^{\prime} 34^{\prime \prime}$ & $99^{\circ} 14^{\prime} 27^{\prime \prime}$ \\
\hline 08205500 & Frio River near Derby, Tex. & 3,429 & $28^{\circ} 44^{\prime} 11 "$ & $99^{\circ} 08^{\prime} 40^{\prime \prime}$ \\
\hline 08206600 & Frio River at Tilden, Tex. & 4,493 & $28^{\circ} 28^{\prime} 02^{\prime \prime}$ & $98^{\circ} 32^{\prime} 50^{\prime \prime}$ \\
\hline 08206700 & San Miguel Creek near Tilden, Tex. & 783 & $28^{\circ} 35^{\prime} 14^{\prime \prime}$ & $98^{\circ} 32^{\prime} 44^{\prime \prime}$ \\
\hline 08206910 & Choke Canyon Reservoir OWC near Three Rivers, Tex. & 5,490 & $28^{\circ} 29^{\prime} 09^{\prime \prime}$ & $98^{\circ} 14^{\prime} 29^{\prime \prime}$ \\
\hline 08207000 & Frio River at Calliham, Tex. & 5,491 & $28^{\circ} 29^{\prime} 31^{\prime \prime}$ & $98^{\circ} 20^{\prime} 47^{\prime \prime}$ \\
\hline 08207500 & Atascosa River near McCoy, Tex. & 530 & $28^{\circ} 51^{\prime} 53^{\prime \prime}$ & $98^{\circ} 20^{\prime} 17^{\prime \prime}$ \\
\hline 08208000 & Atascosa River at Whitsett, Tex. & 1171 & $28^{\circ} 37^{\prime} 19^{\prime \prime}$ & $98^{\circ} 16^{\prime} 52^{\prime \prime}$ \\
\hline 08210000 & Nueces River near Three Rivers, Tex. & 15,427 & $28^{\circ} 25^{\prime} 38^{\prime \prime}$ & $98^{\circ} 10^{\prime} 40^{\prime \prime}$ \\
\hline 08210300 & Ramirena Creek near George West, Tex. & 84.4 & $28^{\circ} 08^{\prime} 30^{\prime \prime}$ & $98^{\circ} 06^{\prime} 11^{\prime \prime}$ \\
\hline 08210400 & Lagarto Creek near George West, Tex. & 155 & $28^{\circ} 03^{\prime} 34^{\prime \prime}$ & $98^{\circ} 05^{\prime} 48^{\prime \prime}$ \\
\hline 08211000 & Nueces River near Mathis, Tex. & 16,660 & $28^{\circ} 02^{\prime} 17^{\prime \prime}$ & $97^{\circ} 51^{\prime} 36^{\prime \prime}$ \\
\hline 08211200 & Nueces River at Bluntzer, Tex. & 16,772 & $27^{\circ} 56^{\prime} 15^{\prime \prime}$ & $97^{\circ} 46^{\prime} 32^{\prime \prime}$ \\
\hline 08211500 & Nueces River at Calallen, Tex. & 16,920 & $27^{\circ} 52^{\prime} 58^{\prime \prime}$ & $97^{\circ} 37^{\prime} 30^{\prime \prime}$ \\
\hline 08211520 & Oso Creek at Corpus Christi, Tex. & 90.3 & $27^{\circ} 42^{\prime} 40^{\prime \prime}$ & $97^{\circ} 30^{\prime} 06^{\prime \prime}$ \\
\hline 08211800 & San Diego Creek at Alice, Tex. & 319 & $27^{\circ} 45^{\prime} 59^{\prime \prime}$ & $98^{\circ} 04^{\prime} 31^{\prime \prime}$ \\
\hline 08211900 & San Fernando Creek at Alice, Tex. & 507 & $27^{\circ} 46^{\prime} 20^{\prime \prime}$ & $98^{\circ} 02^{\prime} 00^{\prime \prime}$ \\
\hline 08212000 & San Fernando Creek near Alice, Tex. & 518 & $27^{\circ} 43^{\prime} 30^{\prime \prime}$ & $97^{\circ} 59^{\prime} 15^{\prime \prime}$ \\
\hline 08212400 & Los Olmos Creek near Falfurrias, Tex. & 476 & $27^{\circ} 15^{\prime} 51^{\prime \prime}$ & $98^{\circ} 08^{\prime} 08^{\prime \prime}$ \\
\hline 08365600 & McKelligon Canyon at El Paso, Tex. & 2.3 & $31^{\circ} 49^{\prime} 20^{\prime \prime}$ & $106^{\circ} 28^{\prime} 09^{\prime \prime}$ \\
\hline 08365800 & Government Ditch at El Paso, Tex. & 6.4 & $31^{\circ} 47^{\prime} 02^{\prime \prime}$ & $106^{\circ} 26^{\prime} 41^{\prime \prime}$ \\
\hline 08373200 & Cibolo Creek near Presidio, Tex. & 276 & $29^{\circ} 34^{\prime} 50^{\prime \prime}$ & $104^{\circ} 21^{\prime} 55^{\prime \prime}$ \\
\hline 08376300 & Sanderson Creek at Sanderson, Tex. & 195 & $30^{\circ} 07^{\prime} 42^{\prime \prime}$ & $102^{\circ} 23^{\prime} 04^{\prime \prime}$ \\
\hline 08411500 & Salt Screwbean Draw near Orla, Tex. & 464 & $31^{\circ} 52^{\prime} 40^{\prime \prime}$ & $103^{\circ} 56^{\prime} 50^{\prime \prime}$ \\
\hline
\end{tabular}


Table 1. U.S. Geological Survey streamflow-gaging stations in Texas with at least 1 year of daily mean streamflow data—Continued.

\begin{tabular}{|c|c|c|c|c|}
\hline $\begin{array}{c}\text { USGS } \\
\text { station } \\
\text { no. }\end{array}$ & USGS station name & $\begin{array}{c}\text { Contributing } \\
\text { drainage } \\
\text { area } \\
\left(\mathrm{mi}^{2}\right)\end{array}$ & Latitude & Longitude \\
\hline 08412500 & Pecos River near Orla, Tex. & 21,210 & $31^{\circ} 52^{\prime} 21^{\prime \prime}$ & $103^{\circ} 49^{\prime} 52^{\prime \prime}$ \\
\hline 08414000 & Pecos River near Mentone, Tex. & 21,650 & $31^{\circ} 40^{\prime} 07^{\prime \prime}$ & $103^{\circ} 37^{\prime} 34^{\prime \prime}$ \\
\hline 08416500 & Pecos River above Barstow (Barstow Canal), Tex. & 21,800 & $31^{\circ} 35^{\prime} 00^{\prime \prime}$ & $103^{\circ} 30^{\prime} 00^{\prime \prime}$ \\
\hline 08420500 & Pecos River at Pecos, Tex. & 22,100 & $31^{\circ} 26^{\prime} 11^{\prime \prime}$ & $103^{\circ} 28^{\prime} 01^{\prime \prime}$ \\
\hline 08424500 & Madera Canyon near Toyahvale, Tex. & 53.8 & $30^{\circ} 52^{\prime} 04^{\prime \prime}$ & $103^{\circ} 58^{\prime} 09^{\prime \prime}$ \\
\hline 08431000 & Toyah Creek near Pecos, Tex. & 1,024 & $31^{\circ} 16^{\prime} 50^{\prime \prime}$ & $103^{\circ} 27^{\prime} 31^{\prime \prime}$ \\
\hline 08431500 & Salt Draw near Pecos, Tex. & 1,882 & $31^{\circ} 18^{\prime} 54^{\prime \prime}$ & $103^{\circ} 29^{\prime} 07^{\prime \prime}$ \\
\hline 08431700 & Limpia Creek above Fort Davis, Tex. & 52.4 & $30^{\circ} 36^{\prime} 48^{\prime \prime}$ & $104^{\circ} 00^{\prime} 04^{\prime \prime}$ \\
\hline 08431800 & Limpia Creek below Fort Davis, Tex. & 227 & $30^{\circ} 40^{\prime} 52^{\prime \prime}$ & $103^{\circ} 47^{\prime} 30^{\prime \prime}$ \\
\hline 08432000 & Limpia Creek near Fort Davis, Tex. & 303 & $30^{\circ} 47^{\prime} 00^{\prime \prime}$ & $103^{\circ} 45^{\prime} 00^{\prime \prime}$ \\
\hline 08433000 & Barrilla Draw near Saragosa, Tex. & 612 & $30^{\circ} 57^{\prime} 28^{\prime \prime}$ & $103^{\circ} 27^{\prime} 33^{\prime \prime}$ \\
\hline 08434000 & Toyah Creek below Toyah Lake near Pecos, Tex. & 3709 & $31^{\circ} 21^{\prime} 00^{\prime \prime}$ & $103^{\circ} 24^{\prime} 00^{\prime \prime}$ \\
\hline 08435500 & Pecos River below Barstow, Tex. & 25,980 & $31^{\circ} 25^{\prime} 00^{\prime \prime}$ & $103^{\circ} 15^{\prime} 00^{\prime \prime}$ \\
\hline 08435600 & Toronto Creek near Alpine, Tex. & 27.9 & $30^{\circ} 21^{\prime} 30^{\prime \prime}$ & $103^{\circ} 42^{\prime} 48^{\prime \prime}$ \\
\hline 08435620 & Alpine Creek at Alpine, Tex. & 18.1 & $30^{\circ} 21^{\prime} 06^{\prime \prime}$ & $103^{\circ} 40^{\prime} 00^{\prime \prime}$ \\
\hline 08435660 & Moss Creek near Alpine, Tex. & 11.3 & $30^{\circ} 20^{\prime} 10^{\prime \prime}$ & $103^{\circ} 38^{\prime} 24^{\prime \prime}$ \\
\hline 08435700 & Sunny Glen Canyon near Alpine, Tex. & 29.7 & $30^{\circ} 22^{\prime} 52^{\prime \prime}$ & $103^{\circ} 44^{\prime} 08^{\prime \prime}$ \\
\hline 08435800 & Coyanosa Draw near Fort Stockton, Tex. & 1,182 & $31^{\circ} 02^{\prime} 27^{\prime \prime}$ & $103^{\circ} 08^{\prime} 15^{\prime \prime}$ \\
\hline 08438100 & Pecos River near Grandfalls, Tex. & 27,810 & $31^{\circ} 19^{\prime} 18^{\prime \prime}$ & $102^{\circ} 53^{\prime} 33^{\prime \prime}$ \\
\hline 08441500 & Pecos River below Grandfalls, Tex. & 27,820 & $31^{\circ} 17^{\prime} 00^{\prime \prime}$ & $102^{\circ} 44^{\prime} 32^{\prime \prime}$ \\
\hline 08446500 & Pecos River near Girvin, Tex. & 29,560 & $31^{\circ} 06^{\prime} 47^{\prime \prime}$ & $102^{\circ} 25^{\prime} 02^{\prime \prime}$ \\
\hline 08447000 & Pecos River near Sheffield, Tex. & 31,600 & $30^{\circ} 39^{\prime} 34^{\prime \prime}$ & $101^{\circ} 46^{\prime} 11^{\prime \prime}$ \\
\hline 08447020 & Independence Creek near Sheffield, Tex. & 763 & $30^{\circ} 27^{\prime} 07^{\prime \prime}$ & $101^{\circ} 43^{\prime} 58^{\prime \prime}$ \\
\hline 08449000 & Devils River near Juno, Tex. & 2,730 & $29^{\circ} 57^{\prime} 48^{\prime \prime}$ & $101^{\circ} 08^{\prime} 42^{\prime \prime}$ \\
\hline 08455000 & Pinto Creek near Del Rio, Tex. & 249 & $29^{\circ} 08^{\prime} 45^{\prime \prime}$ & $100^{\circ} 43^{\prime} 05^{\prime \prime}$ \\
\hline
\end{tabular}


Appendix 1-Summary of the Drainage-Area Ratio Method for Daily Mean Streamflow in Texas 
Blank Page 
This appendix provides a summary of the drainage-area ratio method. We summarize the method, demonstrate application for selected U.S. Geological Survey (USGS) streamflow-gaging stations, and demonstrate application for selected partial-record sites provided by the Texas Commission on Environmental Quality (TCEQ). The method is summarized below; additional limitations of the method are described in section "Limitations of the Drainage-Area Ratio Method."

1. DRAINAGE-AREA RATIO METHOD EQUATION-The drainage-area ratio method, when applied in accordance with the conclusions in the report, is represented by

$$
\frac{Q_{2}}{Q_{1}}=\left(\frac{A_{2}}{A_{1}}\right)^{\phi(F)}
$$

where $Q_{1}$ and $Q_{2}$ are streamflow (concurrent in time), in cubic length per time, for site 1 (gaged) and 2 (ungaged); $A_{1}$ and $A_{2}$ are drainage area, in square length, for site 1 and 2; and $\phi(F)$ is an exponent that is a function of cumulative streamflow percentile ( $F=$ streamflow percentile/100) of site 1 . The method explicitly assumes that the daily mean streamflow percentile for site 2 equals that of site 1 for a given date. For the discussion in this appendix, gaged site 1 is always the USGS station that provides the continuous streamflow data for estimation of the streamflow for ungaged site 2 . This convention holds for circumstances in which site 2 is another USGS station.

2. METHOD EXPONENT-The exponent $\phi$ of the method is a function of streamflow percentile $F / 100$. For this appendix the authors have fit an equation to ordinates listed in table 5 for convenient support of automated computations involving the method. The equation for this "variable $\phi$ " $\left[\phi_{\mathrm{var}}(F)\right]$ follows, and the shape for $\phi_{\mathrm{var}}\left(F_{0 \rightarrow 1}\right)$ is in the small graphic below

$$
\phi_{\text {var }}(F)=\frac{741.66+2827.7\left(1-\left(\frac{1-F^{3.0181}}{3.0181}\right)^{1.8447}\right)}{220.55+4991.4\left(1-\left(\frac{1-F^{9.8835}}{9.8835}\right)^{0.49762}\right)} .
$$

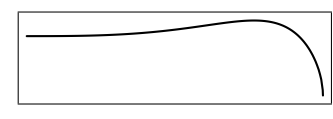

It can be shown that this equation provides a close representation of the ordinates listed in table 5 and the smoothed relation between $\phi$ and streamflow percentile in figure 5. The limits of the $\phi(F)$ are $\phi_{\mathrm{var}}(0)=0.8853$ and $\phi_{\mathrm{var}}(1)=$ 0.6848 .

3. CANDIDATE STATIONS-The drainage-area ratio method requires selection of one or more USGS streamflowgaging stations to provide streamflow estimation for ungaged site 2 . The applicability of the method depends on the hydrologic similarity between the two sites. For example, similar drainage area, slope, climate, recent weather patterns, and hydrologic response of the watersheds increase the likelihood of reliably estimating discharge at an ungaged site using the drainage-area ratio method. The judgment that two watersheds are hydrologically similar is not straightforward. Two recent reports by Asquith and others (2007a,b; http://pubs . usgs .gov/ds/2007/247 and http://pubs .usgs.gov/ds/2007/248) provide a comprehensive summary of daily mean streamflow statistics in Texas. These reports can be used to guide or support an analyst's choice of streamflow-gaging stations to use in the drainage-area ratio method to estimate streamflow at ungaged site 2. Two general restrictions or criteria for candidate stations are identified in the report.

(a) RESTRICTION ON DRAINAGE AREA-To increase the reliability of statistical development of the method, the minimum absolute value of the logarithm of the drainage-area ratio was $0.25-\log$ cycle. For application, however, the minimum drainage-area ratio should not be used when the method is used in practice. Specifically, similar or exactly equal watershed areas for nearby stations are expected to be most appropriate. For example, if the two drainage areas are equal then the drainage-area ratio method equates streamflow for the ungaged site to streamflow for the gaging station. However, an upper limit on the drainage-area ratio is suggested:

$$
\left|\log _{10}\left(\frac{A_{2}}{A_{1}}\right)\right| \leq 1.5 \text { or } \frac{A_{2}}{A_{1}}<31.6 \mid 0.0316 \text { depending on whether } A_{2}>A_{1} \mid A_{2}<A_{1} .
$$

(b) SEPARATION DISTANCE-To increase the hydrologic similarity of two watersheds, a maximum of 100-mile separation distance between stations was identified. Therefore, it is suggested that users of the method limit the distance between the streamflow-gaging station (site 1) and ungaged site 2 to less than about 100 miles. Analysts might have additional information regarding watershed similarity, and therefore relaxation of the separation-distance limit might be necessary. 


\section{1-4 Statewide Analysis of the Drainage-Area Ratio Method for 34 Streamflow Percentile Ranges in Texas}

\section{Demonstration of the Drainage-Area Ratio Method-Estimating Streamflow for Selected USGS Streamflow-Gaging Stations}

To provide a brief demonstration of the drainage-area ratio method, five pairs of selected USGS streamflow-gaging stations were selected. These pairs represent various geographic and hydrologic characteristics of Texas watersheds. The stations are listed in table 1.1, and each evaluation is shown in figures 1.1-1.10.

The drainage-area ratio method can be applied from one station to another and the reverse; therefore, the table lists the stations as ensemble pairings. The right arrow in the table indicates that the station on the left was used to estimate the daily mean streamflow for the station on the right. For each application of the method the streamflow percentiles for the left station were computed. Next, the temporal intersection of the common record of the two stations was determined. From this intersected record, values of observed $\phi$ were computed and are shown in figures 1.1-1.10. A LOWESS smooth line was computed from the data points and is shown in the figures. For computational purposes the smooth line represents a generalized $\phi$ for the two stations. Superimposed on each figure are lines that depict $\phi=1$ and $\phi_{\mathrm{var}}(F)$. Sequences of residuals (errors) between the LOWESS smooth line and each of the two $\phi$ lines were computed for each streamflow percentile of the data. The mean for each sequence subsequently was determined; two numbers result. The ratio of these means represents the relative performance of the $\phi=1$ and $\phi_{\mathrm{var}}(F)$ estimation methods. The ratios are listed in table 1.1.

One-half the ratios listed in the table are greater than 1 , and one-half are less than 1 , which indicates that either $\phi=1$ or $\phi_{\mathrm{var}}(F)$ can be a better approximation of observed $\phi$. However, the data for these stations show that either method of $\phi$ estimation might not be a reliable model of streamflow estimation for any particular site pairing. The figures show tremendous and complex variability in observed $\phi$. The figures also show that there is an inherent dependency of $\phi$ on streamflow probTable 1.1. Summary of comparison of drainage-area ratio method using $\phi=1$ and $\phi_{\mathrm{var}}(F)$ for selected USGS streamflow-gaging stations.

\begin{tabular}{cc}
\hline $\begin{array}{c}\text { Station used to estimate } \\
(\rightarrow) \text { streamflow } \\
\text { at other station }\end{array}$ & $\begin{array}{c}\text { Ratio of mean error } \\
\text { of } \phi=1 \text { to mean } \\
\text { error of } \phi_{\text {var }}(F)\end{array}$ \\
\hline $07299670 \rightarrow 07301410$ & 1.04 \\
$07301410 \rightarrow 07299670$ & .90 \\
$08019000 \rightarrow 08019500$ & 1.06 \\
$08019500 \rightarrow 08019000$ & 1.07 \\
$08037050 \rightarrow 08039100$ & .81 \\
$08039100 \rightarrow 08037050$ & .80 \\
$08167000 \rightarrow 08171000$ & 1.31 \\
$08171000 \rightarrow 08167000$ & 1.35 \\
$08198000 \rightarrow 08200000$ & .68 \\
$08200000 \rightarrow 08198000$ & .77 \\
\hline
\end{tabular}
ability, a feature of the data that figure 5 and $\phi_{\text {var }}(F)$ seek to represent. 


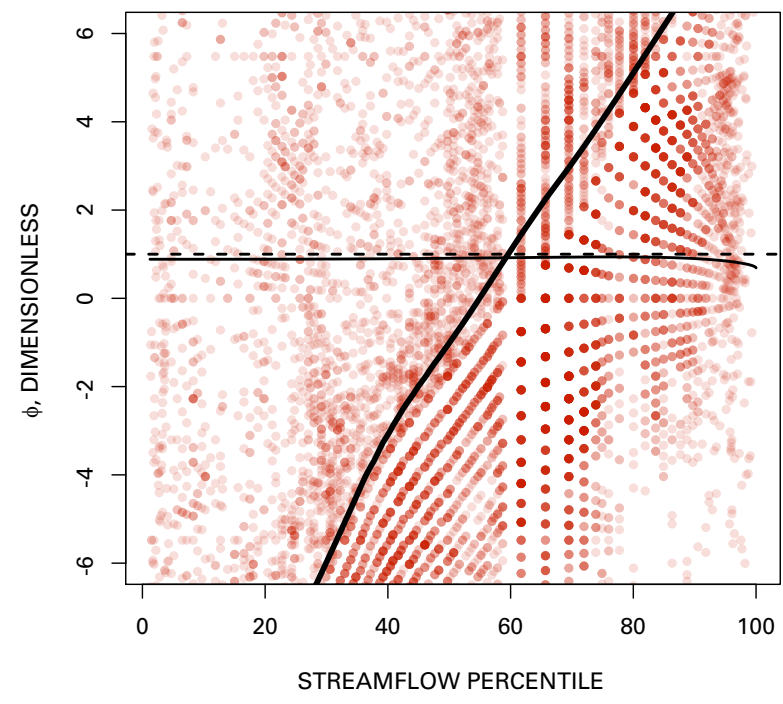

Figure 1.1. Comparison of $\phi(F)$ values using station 07299670 to estimate daily mean streamflow at station 07301410 .

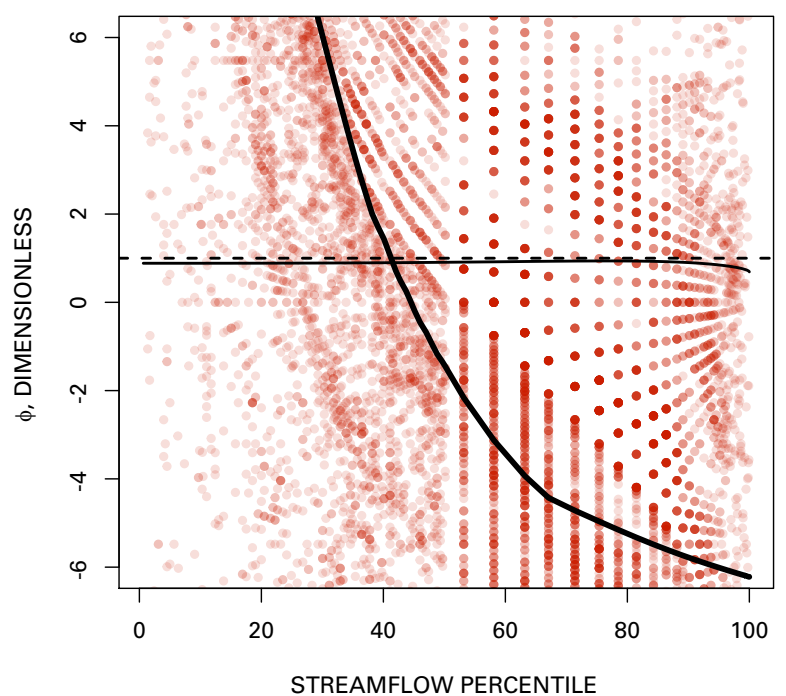

Figure 1.2. Comparison of $\phi(F)$ values using station 07301410 to estimate daily mean streamflow at station 07299670 .

EXPLANATION (figs. 1.1-1.10)

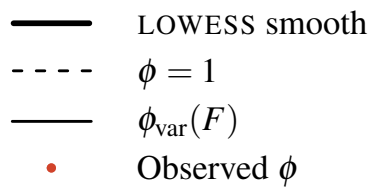

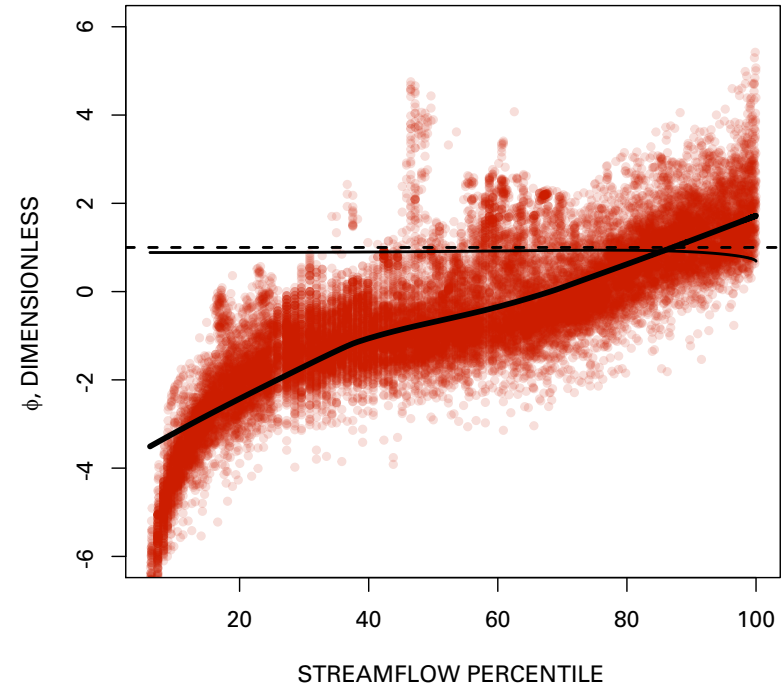

Figure 1.3. Comparison of $\phi(F)$ values using station 08019000 to estimate daily mean streamflow at station 08019500 .

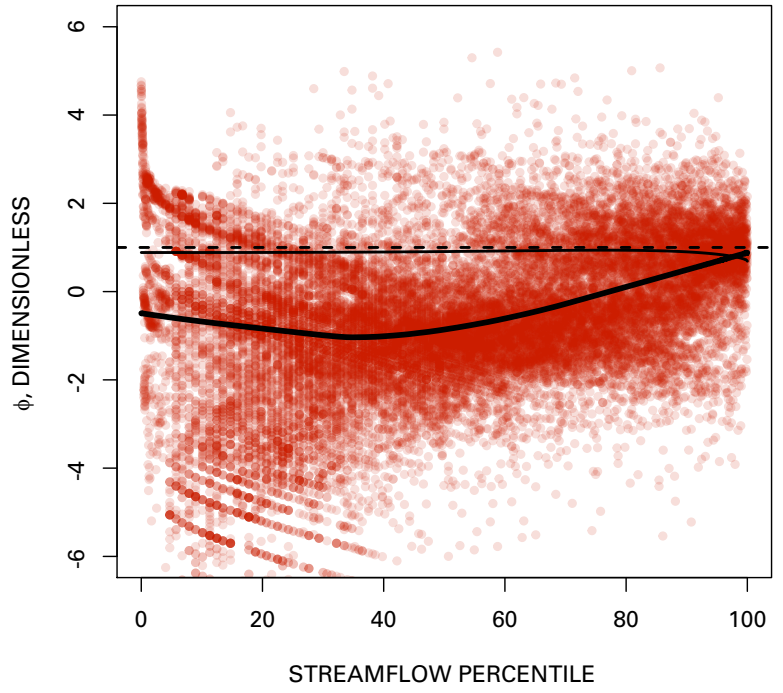

Figure 1.4. Comparison of $\phi(F)$ values using station 08019500 to estimate daily mean streamflow at station 08019000 . 


\section{1-6 Statewide Analysis of the Drainage-Area Ratio Method for 34 Streamflow Percentile Ranges in Texas}

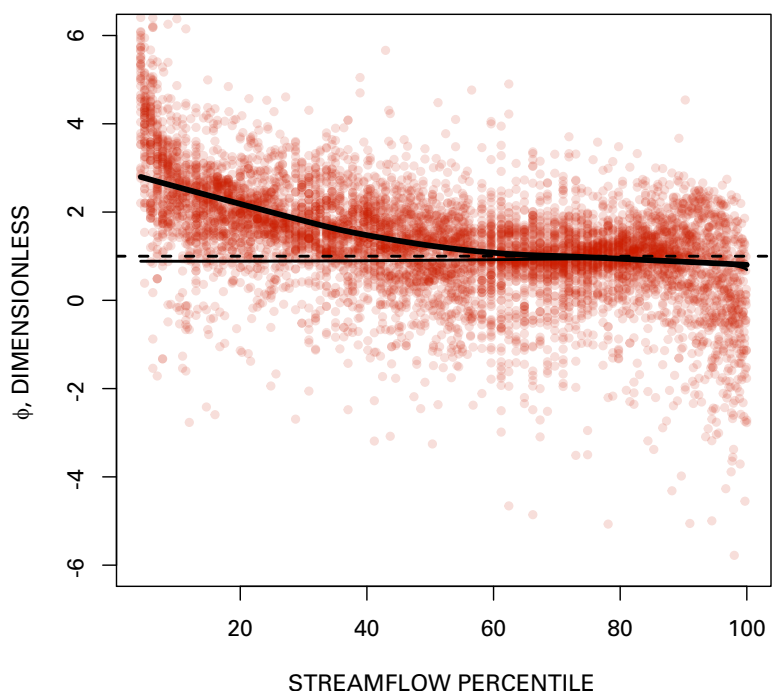

Figure 1.5. Comparison of $\phi(F)$ values using station 08037050 to estimate daily mean streamflow at station 08039100 .

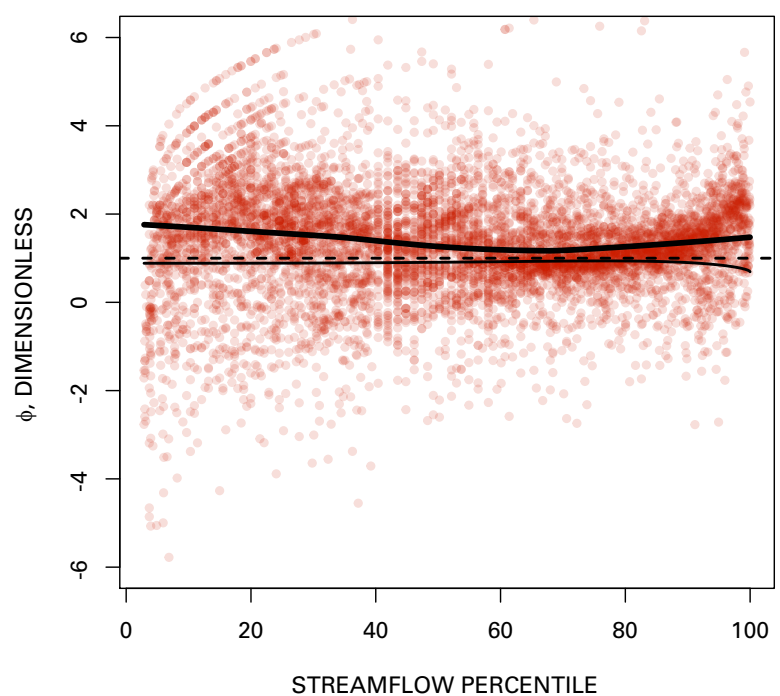

Figure 1.6. Comparison of $\phi(F)$ values using station 08039100 to estimate daily mean streamflow at station 08037050

EXPLANATION (figs. 1.1-1.10)

- LOWESS smooth

- - - $\phi=1$

$-\phi_{\mathrm{var}}(F)$

- $\quad$ Observed $\phi$

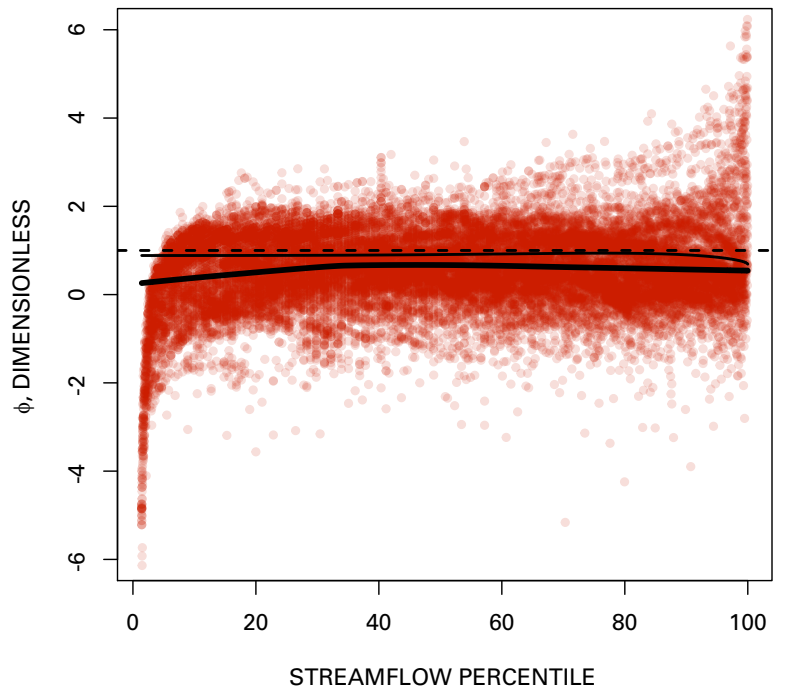

Figure 1.7. Comparison of $\phi(F)$ values using station 08167000 to estimate daily mean streamflow at station 08171000 .

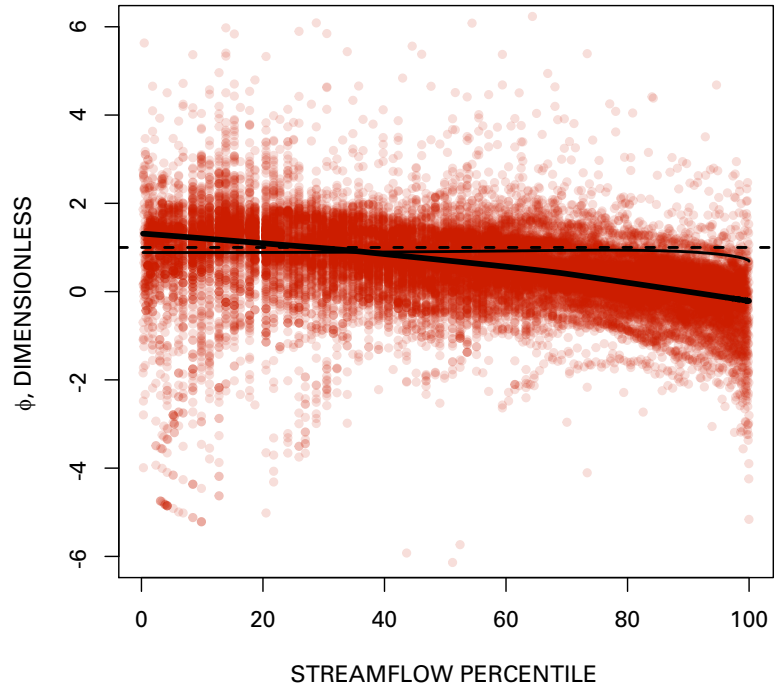

Figure 1.8. Comparison of $\phi(F)$ values using station 08171000 to estimate daily mean streamflow at station 08167000 . 


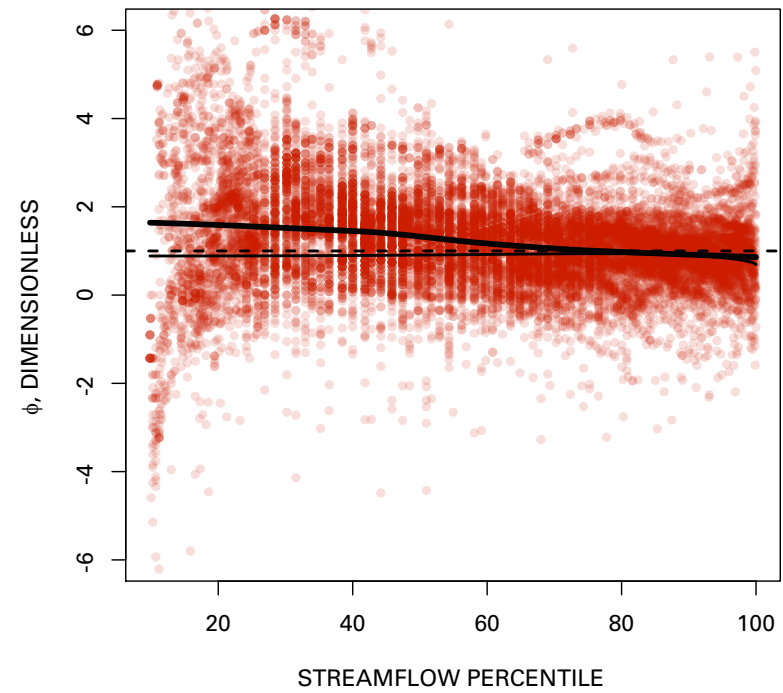

Figure 1.9. Comparison of $\phi(F)$ values using station 08198000 to estimate daily mean streamflow at station 08200000 .

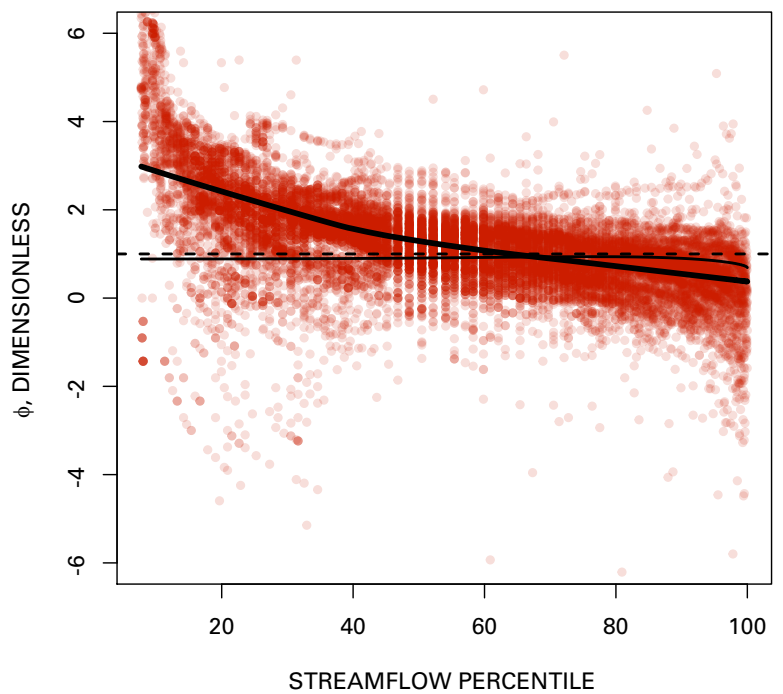

Figure 1.10. Comparison of $\phi(F)$ values using station 08200000 to estimate daily mean streamflow at station 08198000 .

EXPLANATION (figs. 1.1-1.10)

$\begin{array}{ll}- & \text { LOWESS smooth } \\ --- & \phi=1 \\ - & \phi_{\mathrm{var}}(F) \\ -\quad & \text { Observed } \phi\end{array}$

\section{Demonstration of the Drainage-Area Ratio Method-Estimating Streamflow for Selected Monitoring Sites of the Texas Commission on Environmental Quality}

Nine (ungaged) sites, which periodically are monitored by TCEQ, were identified by TCEQ for inclusion in this demonstration of the drainage-area ratio method. The site numbers, names, and drainage areas are listed in table 1.2. The site number and site name are specific to TCEQ. The drainage areas were determined using a 30-meter digital elevation model. The table also lists the number of flow values and USGS stations used for the computations. The number of flow values represents the number of concurrent nonzero flow days at the comparison USGS station. The USGS station number represents the station used in the drainage-area ratio method to estimate streamflow at the TCEQ station. For this demonstration both $\phi_{\text {var }}(F)$ and $\phi=1$ were considered.

A residual $\varepsilon$ is defined as the number of $\log _{10}$ cycles between streamflow measured by TCEQ and concurrent daily mean streamflow of the indicated USGS station, specifically $\varepsilon=\log _{10}\left(Q_{\mathrm{TCEQ}} / Q_{\mathrm{USGS}}\right)$, where $Q$ represents the streamflow for the respective agency. The quantity $\varepsilon\left[\phi_{\mathrm{var}}(F)\right]$ represents the mean $\log _{10}$ residual of streamflow with the \pm indicating the standard deviation. Similarly, $\varepsilon[\phi=1]$ represents the mean $\log _{10}$ residual of streamflow with the \pm indicating the standard deviation. The USGS stations were selected on the basis of regional proximity, hydrologic similarity with the site, and the other criteria identified for application of the drainage-area ratio method. For several of the TCEQ sites, those with less than about four USGS stations shown, too few residuals could be computed because of zero flow values at some USGS stations. Zero streamflow is incompatible with the drainagea-area ratio method. These stations were not used to compute summary statistics of the residuals and are not listed in the table.

The mean residual statistics indicate that considerable average bias for streamflow estimation by the drainage-area ratio method is expected, and the standard deviation statistics indicate that considerable uncertainty in application of the drainage-area ratio method also exists. The residual statistics also indicate, as expected, that the estimates of site streamflow are sensitive to USGS station selection. However, the residual statistics can be interpreted. If a site has generally positive mean residuals then the site has larger-than-expected flow from a regional perspective; whereas, if a site has gen- 


\section{1-8 Statewide Analysis of the Drainage-Area Ratio Method for 34 Streamflow Percentile Ranges in Texas}

erally negative mean residuals then the site has smaller-than-expected flow. The residual statistics in the table indicate that neither $\phi_{\mathrm{var}}(F)$ or $\phi=1$ are preferable. For some sites, such as $12377, \phi=1$ performs better; whereas, for other sites, such as $14942, \phi_{\mathrm{var}}(F)$ performs better. Therefore, the statistics indicate that considerable ambiguity in application of the drainage-area ratio method exists.

In conclusion, we emphasize that application of the drainage-area ratio method discussed in this report is for ungaged sites lacking any streamflow data. Therefore in actual practice, it would not be known whether $\phi_{\mathrm{var}}(F)$ or $\phi=1$ is more appropriate. However, $\phi_{\mathrm{var}}(F)$ is determined by large-scale computations of the historical USGS streamflow database in Texas. The evidence is clear that on average $\phi<1$. For circumstances in which streamflow data actually exist, the $\phi$ of the drainage-area ratio could be computed specific to the ungaged site. However for those circumstances involving streamflow data at an ungaged site, alternative methods of streamflow estimation as noted in the text is preferred. 
Table 1.2. Ungaged sites provided by the Texas Commission on Environmental Quality for inclusion in demonstration of the drainagearea ratio method.

$\left[\varepsilon\left[\phi_{\mathrm{var}}(F)\right]\right.$ represents mean $\log _{10}$ residual of streamflow with \pm indicating standard deviation. Similarly, $\varepsilon[\phi=1]$ represents mean $\log _{10}$ residual of streamflow with \pm indicating standard deviation.]

\begin{tabular}{|c|c|c|c|c|c|c|}
\hline Site number & Site name & $\begin{array}{l}\text { Drainage area } \\
\text { (square miles) }\end{array}$ & $\begin{array}{l}\text { Number of } \\
\text { flow values }\end{array}$ & $\begin{array}{c}\text { USGS station } \\
\text { used for } \\
\text { computation }\end{array}$ & $\varepsilon\left[\phi_{\mathrm{var}}(F)\right]$ & $\varepsilon[\phi=1]$ \\
\hline \multirow{4}{*}{12377} & \multirow{4}{*}{ Pedernales River } & \multirow{4}{*}{440} & 32 & 08150800 & $0.574 \pm 0.663$ & $0.544 \pm 0.622$ \\
\hline & & & 27 & 08152000 & $0.612 \pm 0.862$ & $0.603 \pm 0.680$ \\
\hline & & & 26 & 08152900 & $0.049 \pm 0.278$ & $0.042 \pm 0.278$ \\
\hline & & & 32 & 08153500 & $-0.105 \pm 0.512$ & $-0.077 \pm 0.515$ \\
\hline \multirow{2}{*}{12805} & \multirow{2}{*}{$\begin{array}{l}\text { Cibolo Creek at } \\
\text { Farm to Market } \\
\text { Road } 539\end{array}$} & \multirow{2}{*}{644} & 18 & 08183500 & $-0.343 \pm 0.381$ & $-0.297 \pm 0.385$ \\
\hline & & & 18 & 08186000 & $0.090 \pm 0.403$ & $0.099 \pm 0.404$ \\
\hline \multirow{3}{*}{12841} & \multirow{3}{*}{$\begin{array}{l}\text { Leon Creek at Ruiz } \\
\text { Ranch }\end{array}$} & \multirow{3}{*}{204} & 12 & 08181400 & $-0.197 \pm 1.178$ & $-0.315 \pm 1.204$ \\
\hline & & & 36 & 08181480 & $-0.050 \pm 0.280$ & $-0.047 \pm 0.280$ \\
\hline & & & 32 & 08181500 & $-0.452 \pm 0.404$ & $-0.410 \pm 0.399$ \\
\hline \multirow{5}{*}{13239} & \multirow{5}{*}{$\begin{array}{l}\text { Devils River near } \\
\text { Dolan Creek }\end{array}$} & \multirow{5}{*}{2,897} & 11 & 08128000 & $0.053 \pm 0.373$ & $-0.028 \pm 0.363$ \\
\hline & & & 11 & 08148500 & $0.191 \pm 0.417$ & $0.149 \pm 0.414$ \\
\hline & & & 13 & 08150000 & $-0.194 \pm 0.332$ & $-0.211 \pm 0.331$ \\
\hline & & & 13 & 08190000 & $-0.589 \pm 0.441$ & $-0.654 \pm 0.457$ \\
\hline & & & 8 & 08447020 & $0.006 \pm 0.425$ & $-0.047 \pm 0.431$ \\
\hline \multirow{4}{*}{14942} & \multirow{4}{*}{$\begin{array}{l}\text { Dolan Springs at } \\
\text { Devils River } \\
\text { confuence }\end{array}$} & \multirow{4}{*}{178} & 13 & 08128000 & $0.771 \pm 0.316$ & $0.799 \pm 0.316$ \\
\hline & & & 13 & 08148500 & $0.866 \pm 0.375$ & $0.926 \pm 0.379$ \\
\hline & & & 13 & 08150000 & $0.431 \pm 0.366$ & $0.510 \pm 0.372$ \\
\hline & & & 9 & 08447020 & $0.804 \pm 0.320$ & $0.861 \pm 0.326$ \\
\hline \multirow{5}{*}{15449} & \multirow{5}{*}{$\begin{array}{l}\text { Frio River South of } \\
\text { Sabinal }\end{array}$} & \multirow{5}{*}{880} & 16 & 08192000 & $-0.827 \pm 0.648$ & $-0.796 \pm 0.651$ \\
\hline & & & 12 & 08193000 & $-0.504 \pm 0.836$ & $-0.446 \pm 0.834$ \\
\hline & & & 16 & 08198500 & $-0.231 \pm 0.721$ & $-0.284 \pm 0.716$ \\
\hline & & & 10 & 08204005 & $-1.387 \pm 0.503$ & $-1.470 \pm 0.517$ \\
\hline & & & 14 & 08205500 & $-0.218 \pm 0.655$ & $-0.163 \pm 0.658$ \\
\hline \multirow{2}{*}{15820} & \multirow{2}{*}{$\begin{array}{l}\text { San Felipe Creek at } \\
\text { West Springs }\end{array}$} & \multirow{2}{*}{37.4} & 10 & 08190000 & $0.548 \pm 0.341$ & $0.688 \pm 0.330$ \\
\hline & & & 10 & 08198000 & $1.076 \pm 1.026$ & $1.151 \pm 1.033$ \\
\hline \multirow{2}{*}{15821} & \multirow{2}{*}{$\begin{array}{l}\text { San Felipe Creek at } \\
\text { Blue Hole Gate }\end{array}$} & \multirow{2}{*}{37.6} & 7 & 08190000 & $0.858 \pm 0.361$ & $0.994 \pm 0.340$ \\
\hline & & & 7 & 08198000 & $1.054 \pm 0.637$ & $1.128 \pm 0.640$ \\
\hline \multirow{6}{*}{16701} & \multirow{6}{*}{$\begin{array}{l}\text { South Llano River } \\
\text { on County Road } \\
408\end{array}$} & \multirow{6}{*}{504} & 12 & 08148500 & $-0.518 \pm 0.803$ & $-0.492 \pm 0.803$ \\
\hline & & & 14 & 08150000 & $-1.018 \pm 0.647$ & $-0.965 \pm 0.646$ \\
\hline & & & 14 & 08150800 & $-0.390 \pm 0.875$ & $-0.423 \pm 0.872$ \\
\hline & & & 14 & 08165300 & $-1.304 \pm 0.630$ & $-1.348 \pm 0.633$ \\
\hline & & & 14 & 08165500 & $-1.346 \pm 0.642$ & $-1.369 \pm 0.643$ \\
\hline & & & 14 & 08166000 & $-1.426 \pm 0.646$ & $-1.481 \pm 0.645$ \\
\hline
\end{tabular}


Information regarding water resources in Texas is available at http: //tx.usgs.gov/ 